\title{
BIOLOGICAL AND ASSOCIATED WATER-QUALITY DATA FOR LOWER OLMOS CREEK AND UPPER SAN ANTONIO RIVER, SAN ANTONIO, TEXAS, APRIL-SEPTEMBER 1989
}

By R. Lynn Taylor and Rodger F. Ferreira

U.S. GEOLOGICAL SURVEY

Open-File Report 95-148

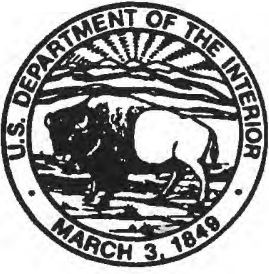

Prepared in cooperation with the

SAN ANTONIO WATER SYSTEM 


\section{U.S. DEPARTMENT OF THE INTERIOR \\ BRUCE BABBITT, Secretary}

U.S. GEOLOGICAL SURVEY

Gordon P. Eaton, Director

Any use of trade, product, or firm names is for descriptive purposes only and does not imply endorsement by the U.S. Government.

For additional information write to:

Copies of this report can be purchased from:

U.S. Geological Survey

Earth Science Information Center

District Chief

Open-File Reports Section

U.S. Geological Survey

8011 Cameron Rd.

Box 25286, Mail Stop 517

Denver Federal Center

Austin, TX 78754-3898

Denver, CO 80225-0046 


\section{CONTENTS}

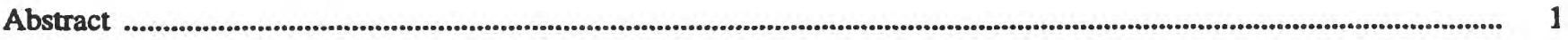

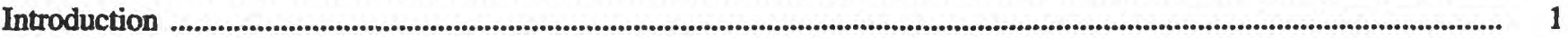

Purpose and Scope ......................................................................................................................................................................... 4

Location and Description of Study Area ........................................................................................................................ 4

Methods ............................................................................................................................................................. 4

Biological Sampling and Analysis ............................................................................................................................ 4

Water-Quality Sampling and Analysis ......................................................................................................... 9

Biological Data

Benthic Macroinvertebrates ........................................................................................................................................................ 9

Periphyton ......................................................................................................................................................................... 10

Phytoplankton ..................................................................................................................................................................... 10

Water-Quality Data ................................................................................................................................................................................. 12

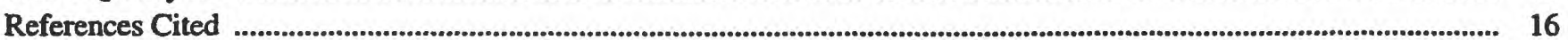

\section{FIGURES}

1. Map showing location of study area ............................................................................................................................. 2

2-4. Schematic diagrams showing sample points at:

2. Site 1, lower Olmos Creek, San Antonio, Texas

3. Site 2, upper San Antonio River, San Antonio, Texas ...................................................................................... 6

4. Site 3, upper San Antonio River, San Antonio, Texas ....................................................................................... 7

5-6. Graphs showing:

5. Total mean density of benthic macroinvertebrates for sites 1-3, lower Olmos Creek and upper San Antonio River, San Antonio, Texas, 1989

6. Mean diversity index and mean maximum diversity index of benthic macroinvertebrates for sites 1-3, lower Olmos Creek and upper San Antonio River, San Antonio, Texas, 1989

7-9. Pie diagrams showing benthic macroinvertebrate classes for:

7. Site 1, lower Olmos Creek, San Antonio, Texas, 1989

8. Site 2, upper San Antonio River, San Antonio, Texas, 1989

9. Site 3, upper San Antonio River, San Antonio, Texas, 1989

10-11. Graphs showing:

10. Total density of periphyton for sites 1-3, lower Olmos Creek and upper San Antonio River, San Antonio, Texas, 1989

11. Diversity index and maximum diversity index of periphyton for sites $1-3$, lower Olmos Creek and upper San Antonio River, San Antonio, Texas, 1989

12-14. Pie diagrams showing periphyton divisions for:

12. Site 1, lower Olmos Creek, San Antonio, Texas, 1989

13. Site 2, upper San Antonio River, San Antonio, Texas, 1989 ..................................................................... 17

14. Site 3, upper San Antonio River, San Antonio, Texas, 1989 ............................................................................ 18

15-16. Graphs showing:

15. Total density of phytoplankton for sites 1-3, lower Olmos Creek and upper San Antonio River,

San Antonio, Texas, 1989

16. Diversity index and maximum diversity index of phytoplankton for sites $1-3$, lower Olmos

Creek and upper San Antonio River, San Antonio, Texas, 1989

17-19. Pie diagrams showing phytoplankton divisions for:

17. Site 1, lower Olmos Creek, San Antonio, Texas, 1989

18. Site 2, upper San Antonio River, San Antonio, Texas, 1989 ...................................................................... 20

19. Site 3, upper San Antonio River, San Antonio, Texas, 1989 
20-21. Graphs showing:

20. Cumulative-percentage size distribution of bottom material collected from riffles at sites 1-3, lower Olmos Creek and upper San Antonio River, San Antonio, Texas, 1989

21. Cumulative-percentage size distribution of bottom material collected from pools at sites 1-3, lower Olmos Creek and upper San Antonio River, San Antonio, Texas, 1989

\section{TABLES}

1-12. Benthic macroinvertebrate species list and density for:

1. Site 1, lower Olmos Creek, San Antonio, Texas, April 3, 1989 ............................................................. 24

2. Site 1, lower Olmos Creek, San Antonio, Texas, April 26, 1989 .......................................................... 26

3. Site 2, upper San Antonio River, San Antonio, Texas, April 4, 1989 ..................................................... 28

4. Site 2, upper San Antonio River, San Antonio, Texas, April 25, 1989 .................................................. 30

5. Site 2, upper San Antonio River, San Antonio, Texas, June 27, 1989 ................................................... 32

6. Site 2, upper San Antonio River, San Antonio, Texas, July 25, 1989 .................................................. 34

7. Site 2, upper San Antonio River, San Antonio, Texas, August 29, 1989 .................................................. 36

8. Site 3, upper San Antonio River, San Antonio, Texas, April 7, 1989 ................................................... 38

9. Site 3, upper San Antonio River, San Antonio, Texas, April 24, 1989 ................................................. 41

10. Site 3, upper San Antonio River, San Antonio, Texas, June 26, 1989 .................................................... 43

11. Site 3, upper San Antonio River, San Antonio, Texas, July 24, 1989 ................................................... 45

12. Site 3, upper San Antonio River, San Antonio, Texas, August 28, 1989 ................................................... 47

13. Pupae densities at sites 1-3, lower Olmos Creek and upper San Antonio River, San Antonio, Texas, 1989

14-16. Periphyton species list and density for:

14. Site 1, lower Olmos Creek, San Antonio, Texas, 1989 ................................................................................ 50

15. Site 2, upper San Antonio River, San Antonio, Texas, 1989 .................................................................. 52

16. Site 3, upper San Antonio River, San Antonio, Texas, 1989 ............................................................... 54

17-19. Phytoplankton species list and density for:

17. Site 1, lower Olmos Creek, San Antonio, Texas, 1989 ...................................................................... 56

18. Site 2, upper San Antonio River, San Antonio, Texas, 1989 ................................................................. 58

19. Site 3, upper San Antonio River, San Antonio, Texas, 1989 ................................................................... 60

20-22. Water-quality data for:

20. Site 1, lower Olmos Creek, San Antonio, Texas, 1989 ..................................................................... 61

21. Site 2, upper San Antonio River, San Antonio, Texas, 1989 ..................................................................... 63

22. Site 3, upper San Antonio River, San Antonio, Texas, 1989 ................................................................. 65

23. Diel fluctuations in water-quality properties at site 2, upper San Antonio River, San Antonio, Texas, September 20-21, 1989

24. Diel fluctuations in water-quality properties at site 3, upper San Antonio River, San Antonio, Texas, September 19-20, 1989 


\begin{tabular}{|c|c|c|}
\hline Multiply & By & To obtain \\
\hline $\begin{array}{r}\text { centimeter }(\mathrm{cm}) \\
\text { cubic meter per second }\left(\mathrm{m}^{3} / \mathrm{s}\right) \\
\text { gram }(\mathrm{g})\end{array}$ & $\begin{array}{l}0.3937 \\
35.31 \\
0.03527\end{array}$ & $\begin{array}{l}\text { inch } \\
\text { cubic foot per second } \\
\text { ounce, avoirdupois }\end{array}$ \\
\hline $\begin{array}{r}\text { kilometer }(\mathrm{km}) \\
\text { meter }(\mathrm{m}) \\
\text { meter per second }(\mathrm{m} / \mathrm{s})\end{array}$ & $\begin{array}{l}0.6214 \\
3.281 \\
3.281\end{array}$ & $\begin{array}{l}\text { mile } \\
\text { foot } \\
\text { foot per second }\end{array}$ \\
\hline $\begin{array}{r}\text { milliliter }(\mathrm{mL}) \\
\text { millimeter }(\mathrm{mm}) \\
\text { square centimeter }\left(\mathrm{cm}^{2}\right)\end{array}$ & $\begin{array}{l}0.06102 \\
0.03937 \\
0.1550\end{array}$ & $\begin{array}{l}\text { cubic inch } \\
\text { inch } \\
\text { square inch }\end{array}$ \\
\hline \multirow[t]{2}{*}{$\begin{array}{r}\text { square meter }\left(\mathrm{m}^{2}\right) \\
\text { square millimeter }\left(\mathrm{mm}^{2}\right)\end{array}$} & $\begin{array}{l}10.76 \\
0.00155\end{array}$ & $\begin{array}{l}\text { square foot } \\
\text { square inch }\end{array}$ \\
\hline & Temperature & \\
\hline degree Celsius $\left({ }^{\circ} \mathrm{C}\right)$ & $1.8 \times{ }^{\circ} \mathrm{C}+32$ & degree Fahrenheit \\
\hline
\end{tabular}

\section{Abbreviated water-quality unlts:}

$\mu \mathrm{g} / \mathrm{g}$, microgram per gram

$\mu \mathrm{g} /$, microgram per liter

$\mathrm{mg} / \mathrm{L}$, milligram per liter 


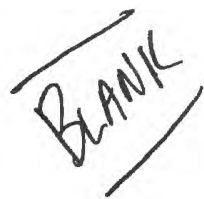




\title{
Biological and Associated Water-Quality Data for Lower Olmos Creek and Upper San Antonio River, San Antonio, Texas, April-September 1989
}

\author{
By R. Lynn Taylor and Rodger F. Ferreira
}

\section{Abstract}

Biological and associated water-quality data were collected from lower Olmos Creek and upper San Antonio River in San Antonio, Texas, during April-September 1989, the first year of a multiyear data-collection program. The data will be used to document water-quality conditions prior to implementation of a proposal to reuse treated wastewater to irrigate city properties in Olmos Basin and Brackenridge Parks and to augment flows in the Olmos Creek/San Antonio River system.

Benthic macroinvertebrate, periphyton, and phytoplankton communities were sampled at three sites along a 4.2-kilometer reach of the Olmos Creek/San Antonio River system. Total mean densities of benthic macroinvertebrates for the three sites ranged from 660 to 10,000 organisms per square meter. The most abundant macroinvertebrates were the classes Insecta (insects), Gastropoda (snails), and Pelecypoda (clams). Total densities of periphyton ranged from 2,900 to 110,000 cells per square millimeter. Cyanophyta (blue-green algae) and Bacillariophyta (diatoms) were the predominant periphyton organisms. Total densities of phytoplankton ranged from 5,000 to 47,000 cells per milliliter. Blue-green algae accounted for more than one-half of the phytoplankton in each sample. Diatoms and Chlorophyta (green algae) made up most of the rest of the phytoplankton. Mean diversity index for the three sites ranged from 0.5 to 2.4 for benthic macroinvertebrates. The diversity index for all sites ranged from 1.4 to 2.8 for periphyton and 1.4 to 2.8 for phytoplankton.
Hardness ranged from 160 to 250 milligrams per liter as calcium carbonate, and alkalinity ranged from 130 to 220 milligrams per liter as calcium carbonate. The largest dissolved nitrite concentration was 0.038 milligram per liter. Dissolved ammonia nitrogen generally was less than 0.100 milligram per liter. The largest total phosphorus concentration was 0.150 milligram per liter, more than one-half of which was dissolved orthophosphate.

Total aluminum and total iron were the only trace elements in water to exceed the reporting threshold by large concentrations. Total aluminum concentrations ranged from 70 to 280 micrograms per liter, and total iron concentrations ranged from 70 to 340 micrograms per liter. Lead was the most prominent trace element in bottom-material samples with concentrations ranging from 30 to 230 micrograms per gram.

Depths and velocities, measured at sample points after benthic macroinvertebrate sampling, ranged from 0.03 to 0.46 meter and from 0.05 to 1.1 meters per second, respectively. Measurable stream discharge ranged from 0.01 to 0.28 cubic meter per second. During three of the sampling periods, no flow was at site 1 .

\section{INTRODUCTION}

Olmos Creek and the San Antonio River are the same channel hydrologically (fig. 1). Olmos Creek is an intermittent stream that runs through the northwest part of San Antonio, Tex. Historically, the San Antonio River began near Incarnate Word College, where springs fed into the channel providing perennial flow. With increased water use, the springs periodically have gone dry. A well drilled at Hildebrand Avenue provides 


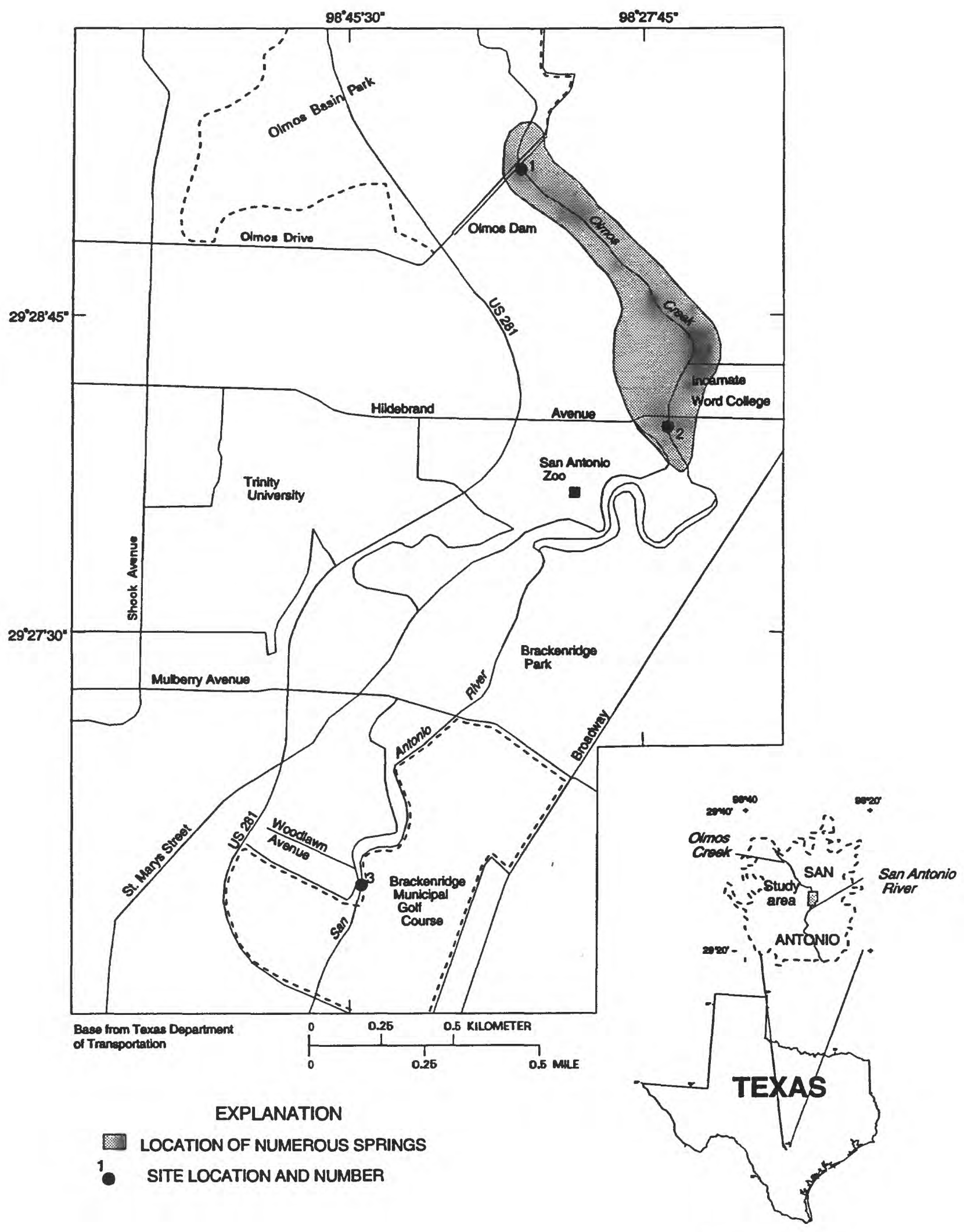

LOCATION MAP

Figure 1. Location of study area.

2 Blological and Associated Water-Quality Data for Lower Olmos Creek and Upper San Antonlo River, San Antonlo, Texas, ApriSeptember 1989 
flow to the river when the springs are not discharging; Hildebrand Avenue is the present boundary between Olmos Creek and the San Antonio River.

The San Antonio River is a valuable aesthetic and economic resource to San Antonio. As a result of population growth and increased demand for water, San Antonio officials have considered the reuse of treated wastewater as part of its regional water-supply system. A proposed plan is to use treated wastewater to irrigate city properties in Olmos Basin and Brackenridge Parks and to augment flows in the Olmos Creek/San Antonio River system. The proposed area for discharging treated wastewater is upstream from the area influenced by Olmos Dam; however, an actual discharge point has not been determined. As a result of the reuse plan, the water-quality conditions in the Olmos Creek/San Antonio River system are to be documented before wastewater reuse. These water-quality conditions then could be compared to water-quality conditions after wastewater reuse to evaluate possible changes. The U.S. Geological Survey, in cooperation with the San Antonio Water System, is conducting a multi-year data-collection program to provide the data to document water-quality conditions in lower Olmos Creek and upper San Antonio River. The program includes collection of selected aquatic-organism and water-quality data; 1989 is the first year of the datacollection program.

Aquatic organisms have long been used as indicators of water quality (Averett, 1981). Initially, only single species were used, but this evolved into communities of organisms being used as indicators (Cummins, 1974). Frenzel (1988) used the benthic community in the Boise River to determine the effects of trace elements from two Boise, Idaho, wastewater-treatment facilities on the quality of the river. Frenzel (1988) determined that trace-element concentrations in effluents did not adversely affect benthic macroinvertebrate communities.

The three aquatic-organism communities sampled for this study were benthic macroinvertebrates, periphyton (algae attached to rocks and similar substrates), and phytoplankton (passively floating algae). Benthic macroinvertebrates are relatively immobile and have a wide range of individual tolerances to environmental stresses (Goodnight, 1973). These characteristics make benthic macroinvertebrates well suited as indicators of water quality. Periphyton also are relatively immobile and can be important as substrate for benthic macroinvertebrates (Hynes, 1970, p. 213).
Phytoplankton generally are considered inhabitants of still water such as lakes, ponds, and large rivers (Wetzel, 1975, p. 288).

Stream reaches can be categorized as riffles, where the water is shallow and fast flowing, or as pools, where the water is deeper and slow flowing. In riffles, fast-flowing water carries much of the sand, silt, and clay through the reach, leaving a larger percentage of boulders, cobbles, and pebbles settled on the streambed. In pools, slower flows allow sand, silt, and clay to settle on the streambed, covering any larger material that might have been deposited during high flows.

The material covering the streambed of riffles and pools serves as substrate for colonization by aquatic organisms. The larger, more complex substrate in riffles provides a larger quantity and variety of habitat niches than the smaller, more uniform substrate in pools. Therefore, though pools may support large populations, they typically support a more limited variety of organisms than riffles (Hynes, 1970, p. 208-210). To compile a large data base of organisms, biological sampling was conducted in the riffles rather than in the pools of each site.

The water-quality properties and constituents of a stream are critical to the type and number of aquatic organisms present (Hynes, 1970). Changes in water quality can shift the species structure of an aquaticorganism community from a mixture of many intolerant and tolerant species toward a few species that can tolerate more adverse conditions (Cairns and Dickson, 1971). Properties and constituents determined during the study included specific conductance, $\mathrm{pH}$, water temperature, dissolved oxygen, major cations and anions, suspended residue, selected dissolved and total nitrogen and phosphorus species, total organic carbon, and trace elements.

The chemical composition of fine bottom material being transported in a stream also is critical to the type of organisms present. Bottom material is moved during periods of increased flows (Colby, 1963) and is a major source of suspended sediment (Horowitz, 1984). Trace elements tend to be associated with the fine fraction of the sediment (Horowitz, 1984) and can be toxic to organisms. Therefore, fine bottom material was sampled to determine the potential availability of trace elements to organisms. In addition, riffle bottommaterial size and distribution were determined because of their influence on the type of aquatic-organism communities present. 


\section{Purpose and Scope}

The purpose of this report is to present benthic macroinvertebrate, periphyton, and phytoplankton data, community characteristics, and associated waterquality data for lower Olmos Creek and upper San Antonio River. The data were collected during AprilSeptember 1989, the first year of data collection.

\section{Location and Description of Study Area}

The study area is within the San Antonio city limits and includes a 4.2-km reach of the Olmos Creek/San Antonio River system from Olmos Dam (a flood-control structure) down into Brackenridge Park (fig. 1). Three sites were selected for sampling. Site 1 is on Olmos Creek, immediately downstream from Olmos Dam, in the intermittent part of the system. Site 2 is $1.3 \mathrm{~km}$ below site 1 , just downstream from Hildebrand Avenue, where the San Antonio River begins. Site 3 also is on the San Antonio River, about $2.9 \mathrm{~km}$ downstream from site 2, next to Brackenridge Municipal Golf Course near Woodlawn Avenue. Schematic diagrams of each site are shown in figures 2-4.

At site 1, ponded water is immediately downstream from Olmos Dam (fig. 2). The sampled reach begins at the lower end of this pond. Three riffle areas, designated as upper, middle, and lower, were sampled at this site because the riffles were too small individually to collect all the needed biological samples. The lower riffle is in two sections separated by a short stretch of deeper, slower water. The approximate area of each riffle, in downstream order, is $13,5.6$, and 6.8 $\mathrm{m}^{2}$.

Site 2 (fig. 3) is near the San Antonio Zoo (fig. 1), but is upstream of any discharges from the zoo. When the channel upstream from Hildebrand Avenue is dry, discharge in the river actually is from an off-channel pond fed by a spring or well (fig. 3), depending on hydrologic conditions. The sampled riffle is approximately $60 \mathrm{~m}$ downstream from the eastern outlet of the pond (fig. 3). The riffle is on the left side of the channel, between a heavily vegetated mid-channel bar and the left bank. Most of the flow runs to the left side of the mid-channel bar over the riffle. The area of the riffle is $27 \mathrm{~m}^{2}$.

Between sites 2 and 3, the river is ponded through the zoo area and again just upstream of site 3 by a low-water crossing. A box culvert connected to a storm drain enters the river just downstream from the low-water crossing (fig. 4). The sampled riffle is down- stream from this culvert. The riffle has an area of $68 \mathrm{~m}^{2}$ and extends $21 \mathrm{~m}$ down the right side of the channel. A mid-channel bar, overgrown with vegetation, splits the river into two channels. Most of the flow is over the riffle area along the right bank.

\section{Methods}

\section{Biological Sampling and Analysis}

Biological sampling was conducted for three aquatic-organism communities-benthic macroinvertebrates, periphyton, and phytoplankton. Samples for benthic macroinvertebrate and periphyton analyses were collected during five sampling periods - at the beginning of April; the end of April; the end of June; the end of July; and the end of August. Samples for phytoplankton analysis were collected at the beginning of April, the end of June, and the end of August. Samples were preserved in the field according to methods described by Britton and Greeson (1988). Samples were analyzed by Chadwick and Associates, a private laboratory in Spotwood, Colo.; analyses consisted of species identification and enumeration. A description of the laboratory procedures (Chadwick and Associates, written commun., 1984) is available from the U.S. Geological Survey Office in Austin or Chadwick and Associates upon request. Each organism reported was identified as distinctly different from other individuals in a sample, regardless of the taxonomic level reported. Organisms were identified to the species level whenever possible. In some instances, the actual species could not be identified, but the species was determined to be distinctly different from other species in a sample. When this happened, the species was identified as "sp.," "sp. 1," and so on, for as many unnamed species as were present in a given genus. A library of these organisms is kept by the laboratory so that any of the same organisms found in the future can be matched and identification will remain consistent throughout the study (Chadwick and Associates, oral commun., 1989). Updates will be made as specimens are collected, making it possible to name previously unidentified species. Organisms in the pupal stages were reported, but were not counted as separate species or used in the computation of diversity index.

Benthic macroinvertebrates were collected from each site using a 0.09- $\mathrm{m}^{2}$ Surber Sampler by cleaning and stirring the bottom substrate to a depth of about 5 $\mathrm{cm}$. Cleaning the bottom substrate consisted of gently 


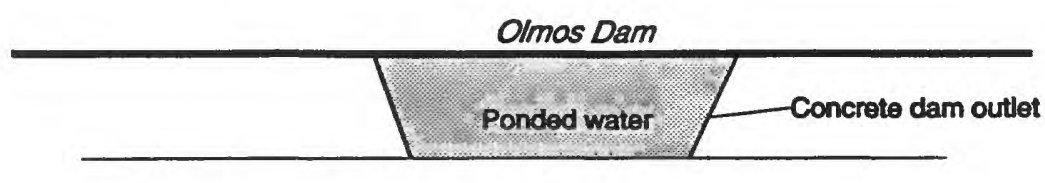

Oimos Drive

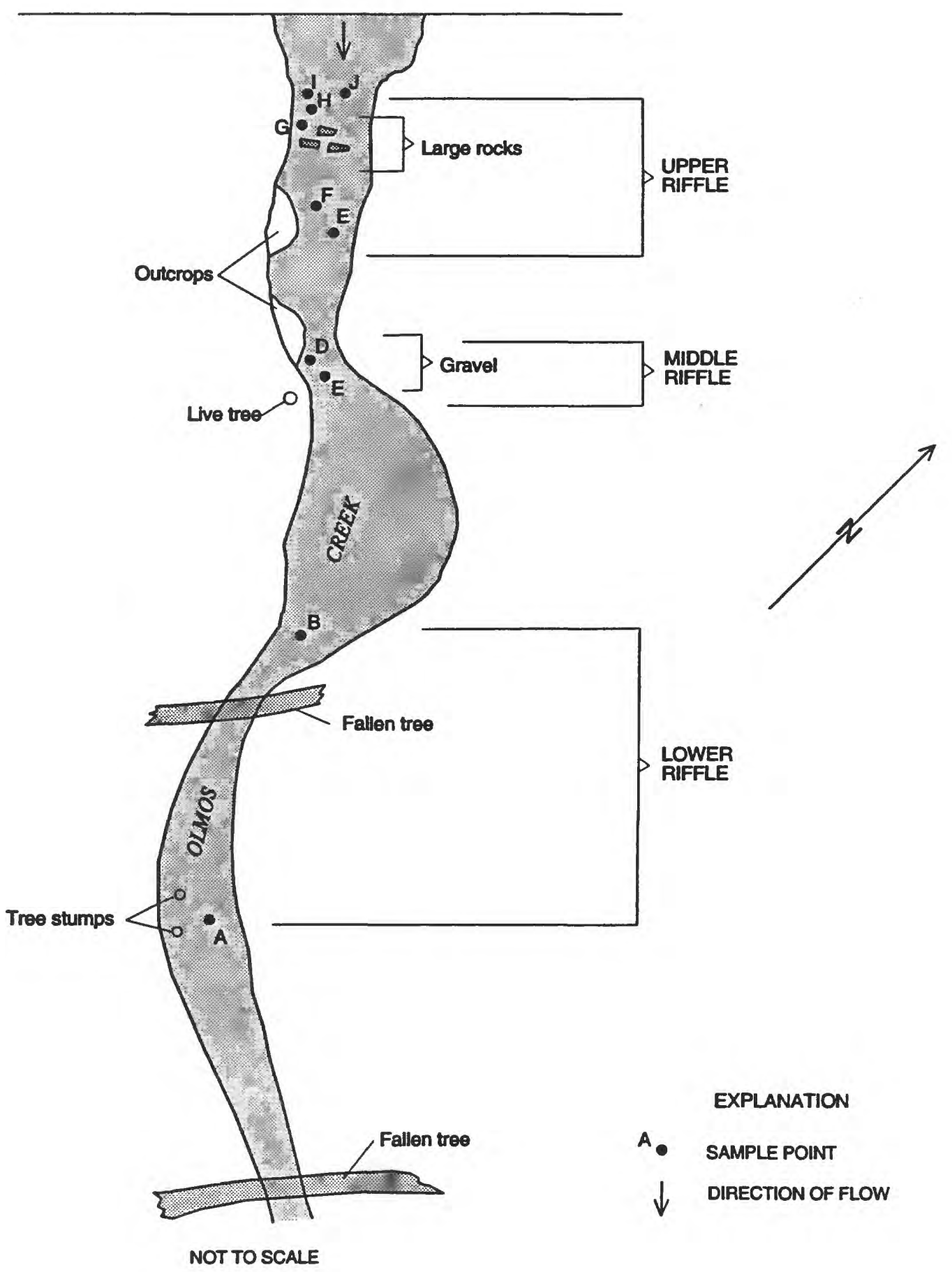

Figure 2. Sample points at site 1, lower Olmos Creek, San Antonio, Texas. 


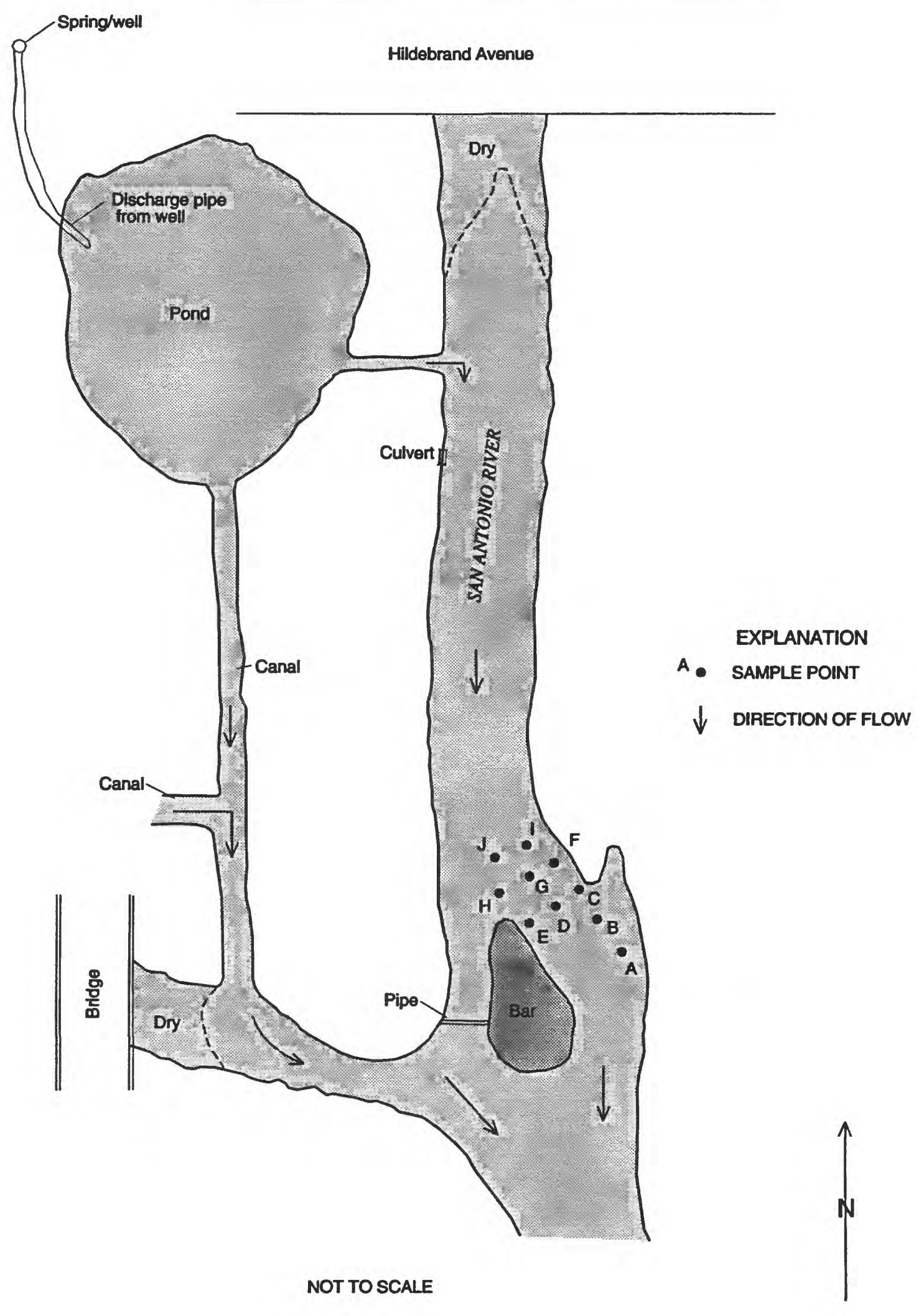

Figure 3. Sample points at site 2, upper San Antonio River, San Antonio, Texas. 


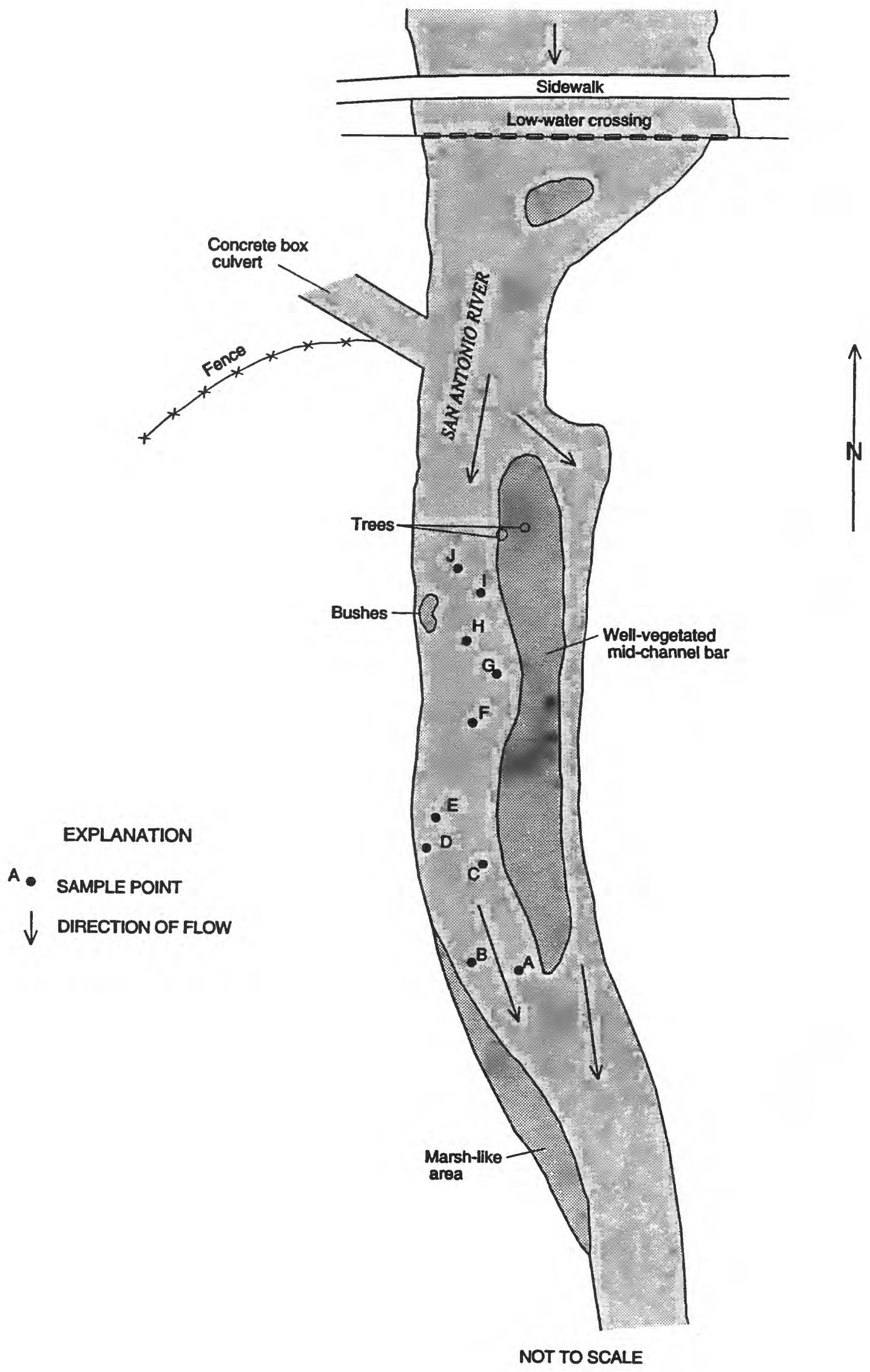

Figure 4. Sample points at site 3, upper San Antonio River, San Antonio, Texas. 
scrubbing the larger rocks (larger than $5 \mathrm{~cm}$ ) by hand at the mouth of the net. The bottom was then stirred up, allowing material to drift into the net. Dislodged organisms were caught in the Surber Sampler net, which had a 212-mm mesh-opening polyester-monofilament screen cloth. Contents of the net were backwashed into a large bucket of water, which was then poured into a U.S. standard $20-\mathrm{cm}$ diameter, no. 70 sieve $(210-\mathrm{mm}$ mesh opening). The unsorted sample retained by the sieve was placed in a sample bottle. During each sampling period, data at 10 sample points (labeled A through J) were collected from each site. To avoid disturbing areas upstream of a given sample point, sampling was started at the downstream end of each riffle.

After each benthic macroinvertebrate sample was collected, depth and velocity measurements were made at the center of each sample point. Depths were taken with a wading rod. All samples were collected in areas where water depths generally were less than 0.3 $\mathrm{m}$ (the height of the Surber Sampler). Velocities were determined at a depth equal to 0.6 times the depth at each sample point, measured from the surface. Velocities were measured using a pygmy current meter with a standard rating (Smoot and Novak, 1968).

Periphyton samples were collected by scraping a 4- $\mathrm{cm}^{2}$ area of material from the surface of randomly selected rocks. Transects were sampled at fixed intervals by dividing the stream into four equal sections and randomly choosing sections from which to select rocks. The number of rocks sampled from each transect, and, therefore, the total number of rocks sampled, varied from site to site. All material from each site was composited into a single sample bottle.

Phytoplankton samples were collected as part of the water-quality samples. The equal-width-increment depth-integrated technique (Guy and Norman, 1970; Wells and others, 1990) was used to collect a composite sample. A sample for phytoplankton then was withdrawn from the composite sample.

Riffle bottom-material size distribution of coarse material (1 mm and larger) was determined at each site during the first and last sampling periods. Bottommaterial size distribution also was determined whenever there were increased flows that might have moved the riffle material between sampling periods. The method to determine the size distribution of bottom material in the riffles was modified from Wolman (1954). This method involved choosing 100 rocks over the length of a reach and measuring the intermediate axis of the rock. Rocks from the streambed were selected from transects laid out in a grid pattern over the riffles. In each case, the first rock touched without looking down was measured in centimeters. The size of large rocks embedded in the streambed was estimated using a ruler, and particles smaller than $1 \mathrm{~mm}$ were reported as less than $0.1 \mathrm{~cm}$. The cumulativepercentage distribution then was computed.

A descriptive statistic called diversity index was computed for each sample. This statistic is a summary of two properties of community structure-the number of different kinds of organisms present and their relative abundance (evenness). For two samples with the same number of taxa, the sample that has the most even distribution of organisms among taxa will have the greatest diversity. Conversely, if the two samples have the same distribution of organisms among taxa, the sample with the most taxa will have the greatest diversity. A modification of Shannon's equation (Shannon and Weaver, 1949) has been used widely (Wilhm and Dorris, 1968) and is presented in this report in the following form:

$$
H=-\sum_{i=1}^{s}\left(\frac{n_{i}}{n}\right) \ln \left(\frac{n_{i}}{n}\right),
$$

where $H^{\prime}=$ diversity index or information content of

$$
\begin{aligned}
& \text { the sample; } \\
& s=\text { number of taxa in the sample; } \\
& n=\text { total number of individuals in the } \\
& \text { collection; } \\
& n_{i}=\text { number of individuals in the } i \text { th taxa; and } \\
& \text { In = natural logarithm. }
\end{aligned}
$$

The maximum diversity possible for the number of taxa in the sample is given as:

$$
H(\max )=-\sum_{i=1}^{s}\left(\frac{1}{s}\right) \ln \left(\frac{1}{s}\right)=\ln (s),
$$

where $H(\max )=$ maximum diversity of the sample.

A measure of evenness of distribution of individuals among all the taxa in the sample is:

$$
J=\frac{H}{H(\max )},
$$

where $J=$ evenness of taxa in the sample. 


\section{Water-Quality Sampling and Analysis}

Water-quality sampling was conducted during five sampling periods-at the beginning of April; the end of April; the end of June; the end of July; and the end of August-using the equal-width-increment depth-integrated technique (Guy and Norman, 1970; Wells and others, 1990). Samples were collected from one cross section, as close as possible to the sampled riffles, where the flow was uniform. Equipment used to obtain samples for chemical analysis was washed with detergent and rinsed thoroughly with tap water and deionized water. Equipment used to collect samples for trace-element analysis was rinsed with a 10-percent hydrochloric acid solution, then with deionized water. All sampling equipment was given a final rinse with native water. Samples were filtered and treated in the field, stored at $4^{\circ} \mathrm{C}$, and shipped within 2 days of collection to the U.S. Geological Survey National Water Quality Laboratory, Arvada, Colo., for chemical analysis. Fixed-endpoint alkalinity and 5-day biochemical oxygen demand were determined at the U.S. Geological Survey office in San Antonio according to methods described by Wells and others (1990).

Stream discharge was measured at or near the sampled riffle using standard U.S. Geological Survey procedures after invertebrate sampling was completed. Water-quality properties, including specific conductance, $\mathrm{pH}$, temperature, and dissolved oxygen, also were determined when discharge was measured.

Fine bottom-material samples were obtained from pools upstream of sampled riffles whenever water-quality samples were obtained. Each bottommaterial sample was a composite of four to five scrapings from the top $5 \mathrm{~cm}$ of bed material. The bottom material was collected with a wide-mouth plastic jar and composited in a plastic dish. The composited bottom material was mixed, and 50 to $100 \mathrm{~g}$ were removed for the sample. Samples for trace-element analysis were shipped to the National Water Quality Laboratory within 2 days of collection.

During the first and last sampling periods, an additional sample was removed from the composited pool bottom material to determine fine bottom-material size distribution. Samples were analyzed at the U.S. Geological Survey office in Austin using a technique modified from Guy (1969). The material was placed in size classes: less than $0.0625 \mathrm{~mm}, 0.0625$ to $0.125 \mathrm{~mm}$, 0.125 to $0.25 \mathrm{~mm}, 0.25$ to $0.5 \mathrm{~mm}, 0.5$ to $1 \mathrm{~mm}$, and larger than $1 \mathrm{~mm}$. The percentage, by weight, of mate- rial was determined for each size class, and the cumulative-percentage distribution then was computed.

After the last water-quality sampling period, specific conductance, $\mathrm{pH}$, temperature, and dissolved oxygen also were determined over a 24-hour period. These diel studies were undertaken when flows generally were lowest and temperatures were highest. Site 2 was sampled September 20-21, and site 3 was sampled September 19-20. Site 1 had no flow.

\section{BIOLOGICAL DATA}

All benthic macroinvertebrate data collected, except organisms in the pupal stage, are presented in tables 1-12 (at end of report). Total density, at the bottom of each table, is the sum of the organism densities at each sample point. Mean density represents the mean of organisms of that species per square meter for the 10 sample points. Total taxa is the total number of different taxa sampled at each site. The point depth and velocity, modified Shannon-Weaver diversity index, maximum diversity index, and evenness are presented at the bottom of each table. Densities for organisms in the pupal stage are presented in table 13 (at end of report).

Periphyton data are presented in tables 14-16 (at end of report), and phytoplankton data are presented in tables 17-19 (at end of report). The single density listed for each site on each date is a composite of all samples collected. The total density, total taxa, modified Shannon-Weaver diversity index, maximum diversity index, and evenness are summarized at the bottom of tables 14-19.

Site 1 was sampled for benthic macroinvertebrates and periphyton on April 3 and April 26, during only two sampling periods, because there was no surface flow over the riffle areas during the June, July, and August sampling periods. Sampling with Surber nets requires flowing water to wash material into the net area (Britton and Greeson, 1988). Site 1 was sampled for phytoplankton only on April 3, also because of noflow conditions during other sampling periods.

\section{Benthic Macroinvertebrates}

Total mean densities of benthic macroinvertebrates for the three sites ranged from 660 to 10,000 organisms $/ \mathrm{m}^{2}$ (fig. 5, tables $1-12$ ). Sites 1 and 3 had the largest total mean densities during the spring $(10,000$ organisms $/ \mathrm{m}^{2}$ on April 3 and 5,900 organisms $/ \mathrm{m}^{2}$ on April 7, respectively). Site 3 had the largest total mean 
densities during the summer months, ranging from 1,200 organisms $/ \mathrm{m}^{2}$ in July to $1,800 \mathrm{organisms} / \mathrm{m}^{2}$ in June. Site 2 consistently had the smallest total mean densities for each sampling period, ranging from 660 to 1,400 organisms $/ \mathrm{m}^{2}$. The modified Shannon-Weaver mean diversity index ranged from 0.5 to 2.4 (fig. 6 , tables 1-12). Mean diversity index values at site 1 were 1.5 on April 3 and 2.1 on April 26. Mean diversity index ranged from 0.5 to 1.9 at site 2 and from 1.8 to 2.4 at site 3 .

The taxonomic structure of macroinvertebrates, broken down by class (except Mollusca) for each site, is shown in figures 7-9. The phylum Mollusca was used to simplify discussions and figures by combining the classes Gastropoda (snails) and Pelecypoda (clams); individual classes of less than 1 percent are not shown. The most abundant macroinvertebrate at sites 1 and 3 was the class Insecta (insects). At site 1 (fig. 7), the majority of the remaining organisms were snails and clams. At site 2 (fig. 8), the most abundant macroinvertebrates were snails and clams, with the remaining organisms mostly insects and Turbellaria (flatworms). Small densities of Oligochaeta (worms) and other classes were present in various samples. At site 3 (fig. 9), the remaining organisms (after insects) were mostly snails, clams, and flatworms.

Depths and velocities at sample points are included with benthic macroinvertebrate data in tables 1-12. Depths were 0.03 to $0.09 \mathrm{~m}$ at site $1,0.09$ to 0.27 $\mathrm{m}$ at site 2 , and 0.15 to $0.46 \mathrm{~m}$ at site 3 . Velocities were 0.05 to $0.59 \mathrm{~m} / \mathrm{s}$ at site $1,0.05$ to $0.33 \mathrm{~m} / \mathrm{s}$ at site 2 , and 0.18 to $1.1 \mathrm{~m} / \mathrm{s}$ at site 3 .

Organisms in the pupal stage are presented in table 13. Diptera (true flies) were the only class of organisms for which the pupae could not be identified uniquely. They were, however, present and reported.

\section{Periphyton}

The total densities of periphyton for all sites are shown in figure 10 (tables 14-16). Site 1 had total densities of 2,900 cells/ $/ \mathrm{mm}^{2}$ on April 3 and 5,600 cells $/ \mathrm{mm}^{2}$ on April 26. Total densities ranged from 7,800 to 110,000 cells $/ \mathrm{mm}^{2}$ at site 2 , and from 4,300 to 66,000 cells $/ \mathrm{mm}^{2}$ at site 3 . The modified ShannonWeaver diversity index is shown in figure 11 (tables 14-16). Site 1 diversity index values were 1.8 on April 3 and 2.0 on April 26. Diversity index ranged from 1.4 to 2.8 at site 2 , and from 2.0 to 2.5 at site 3 .
The taxonomic structure of periphyton, broken down by division for each site, is shown in figures 1214. The predominant periphyton organisms were members of the divisions Cyanophyta (blue-green algae) and Bacillariophyta (diatoms). Organisms in the division Chlorophyta (green algae) also were prevalent in many samples.

At site 1 (fig. 12), blue-green algae were the most abundant periphyton, comprising more than one-half of the total densities. Diatoms accounted for most of the remaining periphyton.

Blue-green algae and diatoms predominated in samples from site 2 (fig. 13). Green algae constituted less than one-fourth of the total densities. The only other division to contribute more than 5 percent of the total density in any sample was Euglenophyta (euglenoids) on August 29.

Site 3 (fig. 14) was dominated by blue-green algae and diatoms, with blue-green algae the predominant organism for most sample dates. Diatoms were the predominant organism on April 7. Green algae accounted for most of the remaining organisms.

\section{Phytoplankton}

Total densities of phytoplankton for all sites are shown in figure 15 (tables 17-19). Site 1 had a total density of 35,000 cells/mL on April 3. Total densities at site 2 were 12,000 cells/mL (April 4), 19,000 cells/mL (June 27), and 30,000 cells/mL (August 29). Site 3 had total densities of 5,000 cells/mL (April 7), 40,000 cells/mL (June 26), and 47,000 cells/mL (August 28). The modified Shannon-Weaver diversity index is shown in figure 16 (tables 17-19). The diversity index at site 1 was 2.8 on April 3. Diversity index values at site 2 were 2.5 (April 4), 1.7 (June 27), and 1.6 (August 29). Site 3 diversity index values were 2.1 (April 7), 1.5 (June 26), and 1.4 (August 28).

The taxonomic structure of phytoplankton, broken down by division for each site, is shown in figures 17-19. Blue-green algae predominated, accounting for more than one-half of the total density of phytoplankton in each sample. Diatoms and green algae made up most of the remaining phytoplankton.

At site 1 (fig. 17), blue-green algae were the most abundant phytoplankton, constituting more than onehalf of the total density. Green algae were next in abundance with less than one-half of the total density. Diatoms constituted less than one-fourth of the total density. 


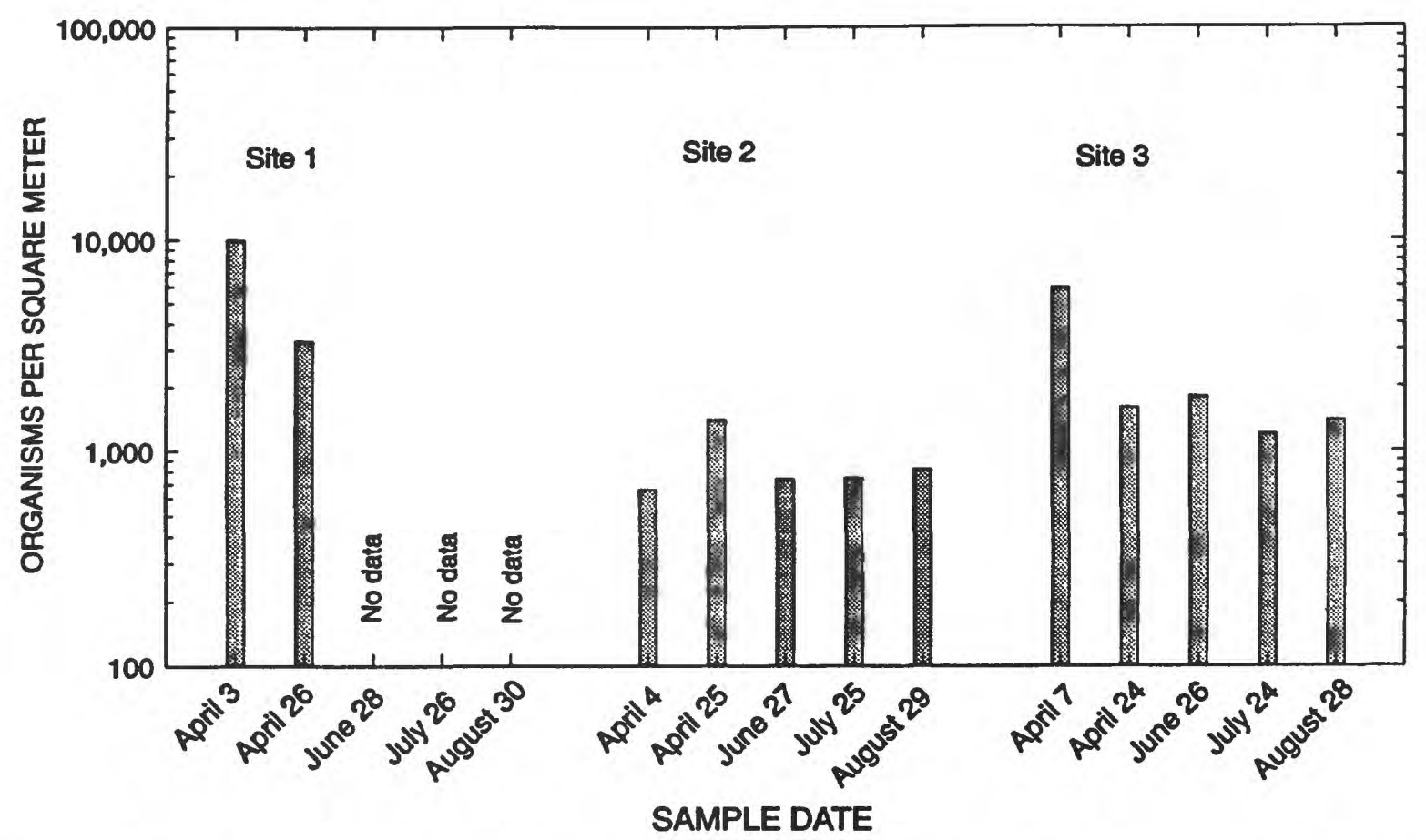

Figure 5. Total mean density of benthic macroinvertebrates for sites 1-3, lower Olmos Creek and upper San Antonio River, San Antonio, Texas, 1989.

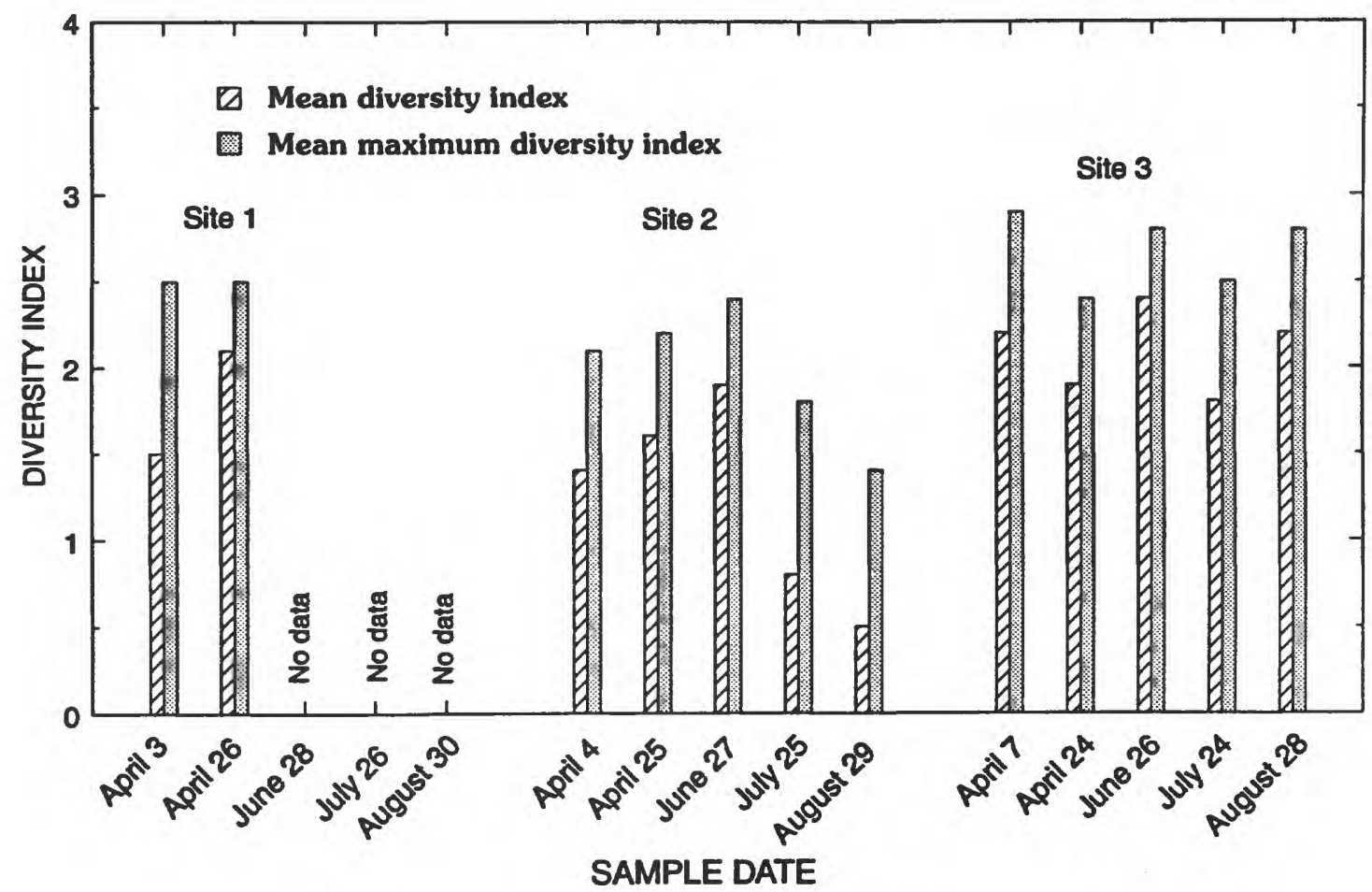

Figure 6. Mean diversity index and mean maximum diversity index of benthic macroinvertebrates for sites 1-3, lower Olmos Creek and upper San Antonio River, San Antonio, Texas, 1989. 

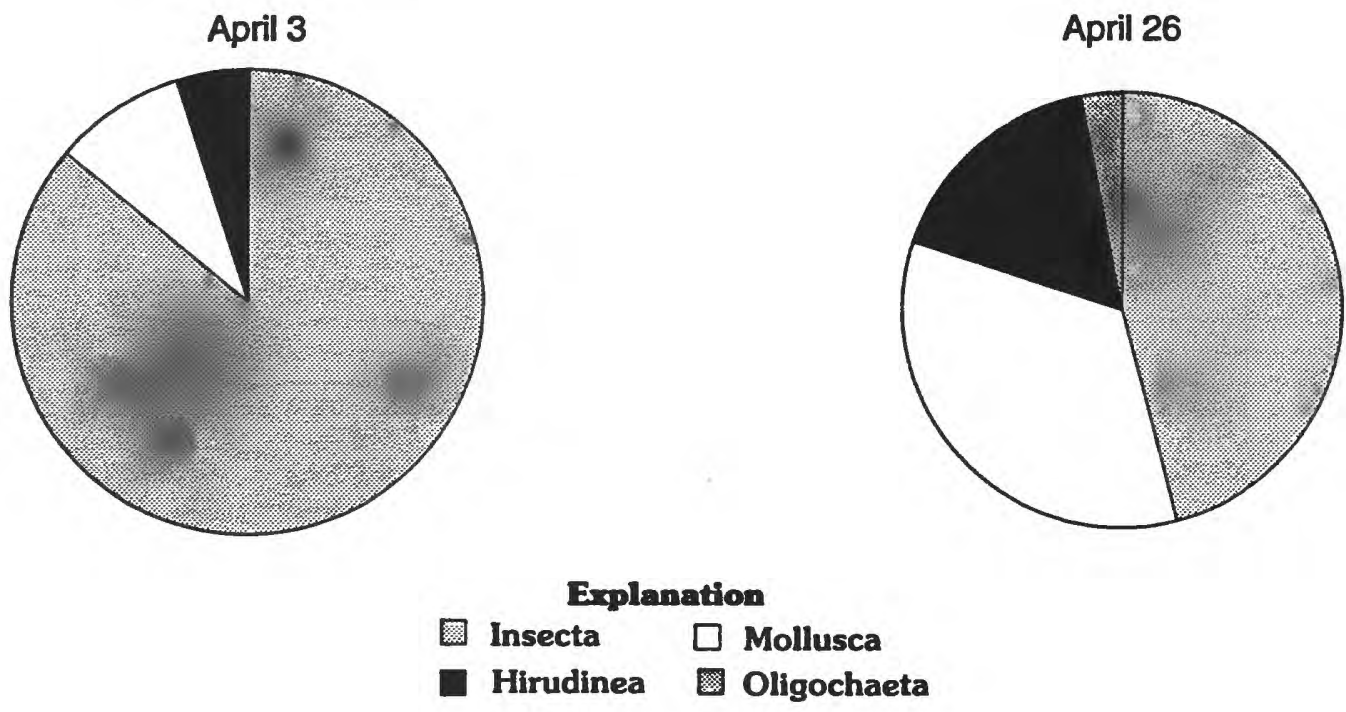

Note: Mollusca is a phylum combining the classes Gastropoda and Pelecypoda

Figure 7. Benthic macroinvertebrate classes for site 1, lower Olmos Creek, San Antonio, Texas, 1989.

At site 2 (fig. 18), blue-green algae ranged from more than one-half to more than three-fourths of the total density (April 4). The remaining phytoplankton organisms at site 2 were mostly diatoms and green algae.

Blue-green algae ranged from more than onehalf to more than three-fourths of the total density at site 3 (fig. 19). Diatoms, green algae, and euglenoids constituted most of the remaining phytoplankton. Diatoms accounted for about one-fifth of the total density on June 26 and August 28.

The bottom material in riffles can influence the type of aquatic-organism communities present. Size distributions of bottom material collected from riffles at sites 1-3 are shown in figure 20. Samples were collected during the first sampling period at sites 1 and 2 and during the first and last sampling period at site 3 . At site 1, a sample also was collected on April 26 to determine if high flows during April had affected the size distribution of the bottom material. These graphs show that the bottom substrate consisted predominantly of material less than $10 \mathrm{~cm}$ along the median axis.

\section{WATER-QUALITY DATA}

Results of the chemical analyses are presented in tables 20-22 (at end of report). These tables present water-quality properties and constituents, including specific conductance, $\mathrm{pH}$, temperature, dissolved oxygen, major ions, suspended residue, selected dissolved and total nitrogen and phosphorus species, total organic carbon, and trace elements in water and bottom material. Diel fluctuations of water-quality properties at sites 2 and 3 are presented in tables 23 and 24 (at end of report). Water-quality properties include specific conductance, $\mathrm{pH}$, temperature, and dissolved oxygen. Measurable stream discharge was $0.01 \mathrm{~m}^{3} / \mathrm{s}$ at site 1. During the June, July, and August sampling periods, there was no flow at site 1 . Discharge ranged from 0.05 to $0.08 \mathrm{~m}^{3} / \mathrm{s}$ at site 2 and from 0.18 to $0.28 \mathrm{~m}^{3} / \mathrm{s}$ at site 3 (tables 20-22). The largest biochemical oxygen demand determined was $4.2 \mathrm{mg} / \mathrm{L}$ at site 1 on April 3. Biochemical oxygen demand ranged from 0.6 to 1.6 $\mathrm{mg} / \mathrm{L}$ at site 2 and from 0.9 to $1.9 \mathrm{mg} / \mathrm{L}$ at site 3 . Hardness ranged from $160 \mathrm{mg} / \mathrm{L}$ as $\mathrm{CaCO}_{3}$ at site 1 to 250 $\mathrm{mg} / \mathrm{L}$ as $\mathrm{CaCO}_{3}$ at site 2. Alkalinity ranged from 130 $\mathrm{mg} / \mathrm{L}$ as $\mathrm{CaCO}_{3}$ at site 1 to $220 \mathrm{mg} / \mathrm{L}$ as $\mathrm{CaCO}_{3}$ at 

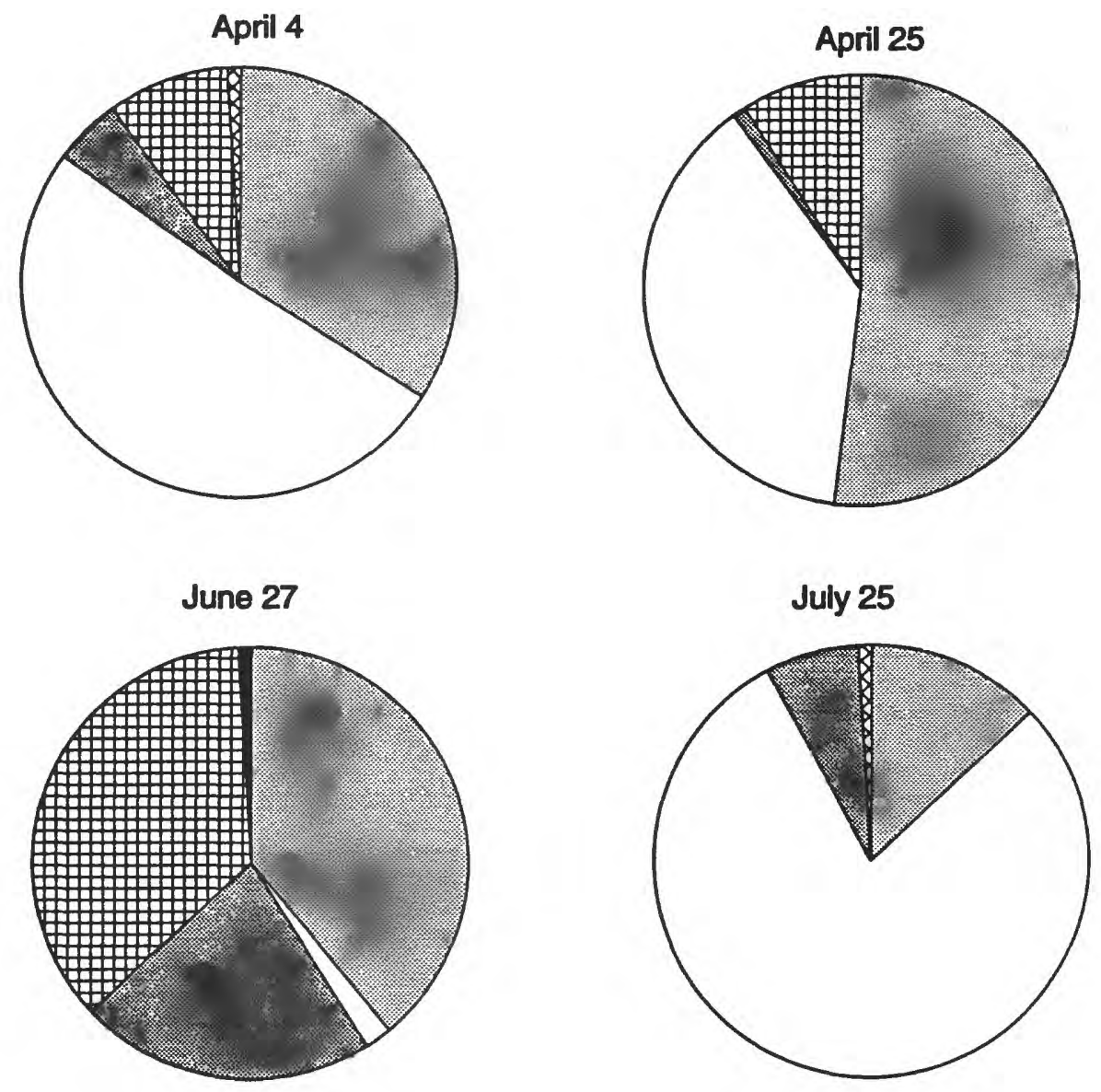

August 29

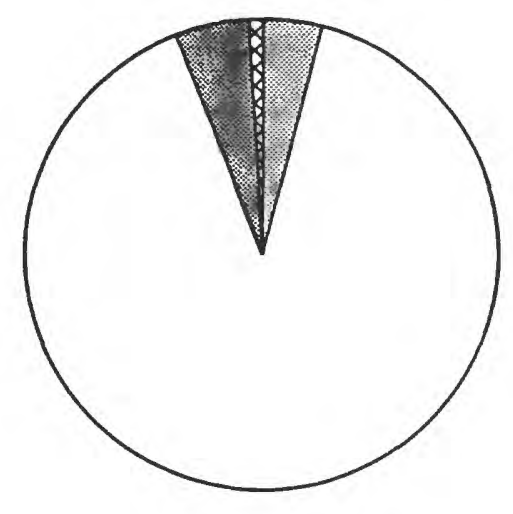

Explanation

Insecta

$\square$ Mollusca

Oligochaeta

田 Turbellaria

- Hirudinea

Sum of classes that individually compose less than 1 percent of the total

Note: Mollusca is a phylum combining the classes Gastropoda and Pelecypoda

Figure 8. Benthic macroinvertebrate classes for site 2, upper San Antonio River, San Antonio, Texas, 1989. 

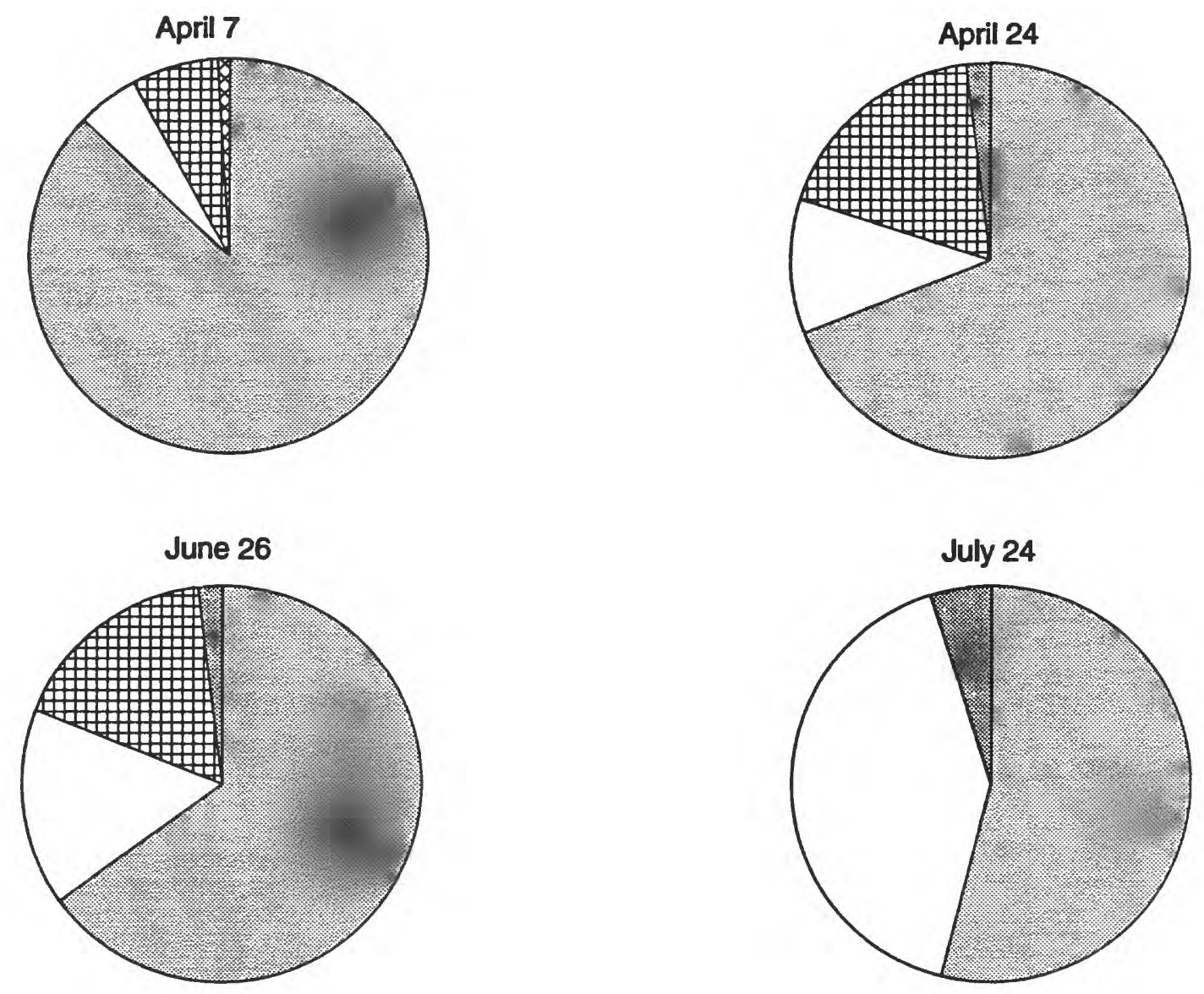

\section{Explanation}

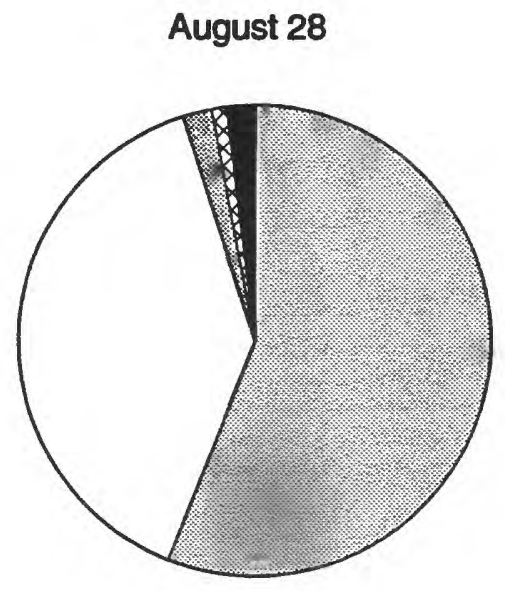
Insecta
$\square$ Mollusca
Oligochaeta
田 Turbellaria
Hirudinea

Sum of classes that individually compose less than 1 percent of the total

Note: Mollusca is a phylum combining the classes Gastropoda and Pelecypoda

Figure 9. Benthic macroinvertebrate classes for site 3, upper San Antonio River, San Antonio, Texas, 1989. 


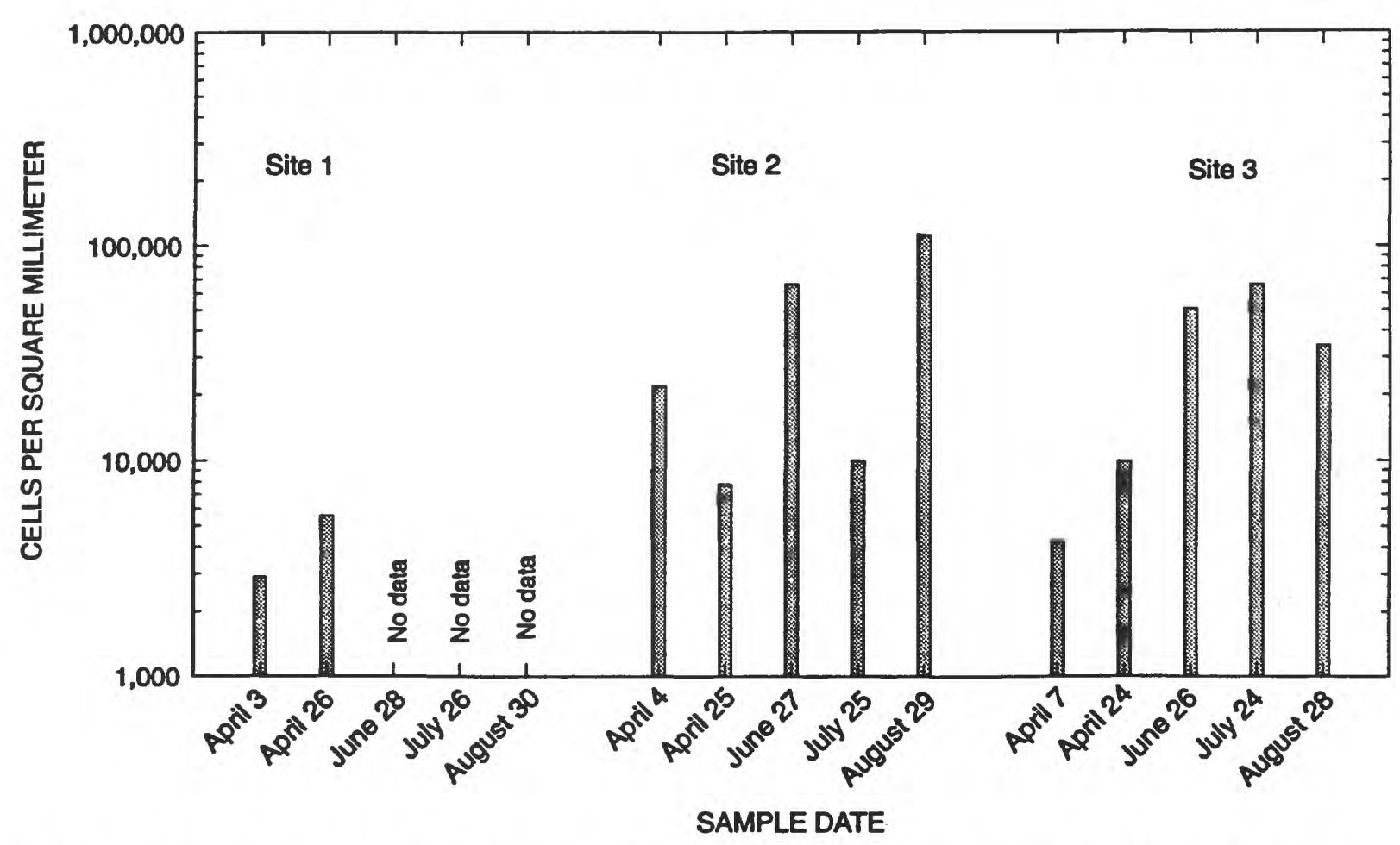

Figure 10. Total density of periphyton for sites 1-3, lower Olmos Creek and upper San Antonio River, San Antonio, Texas, 1989.

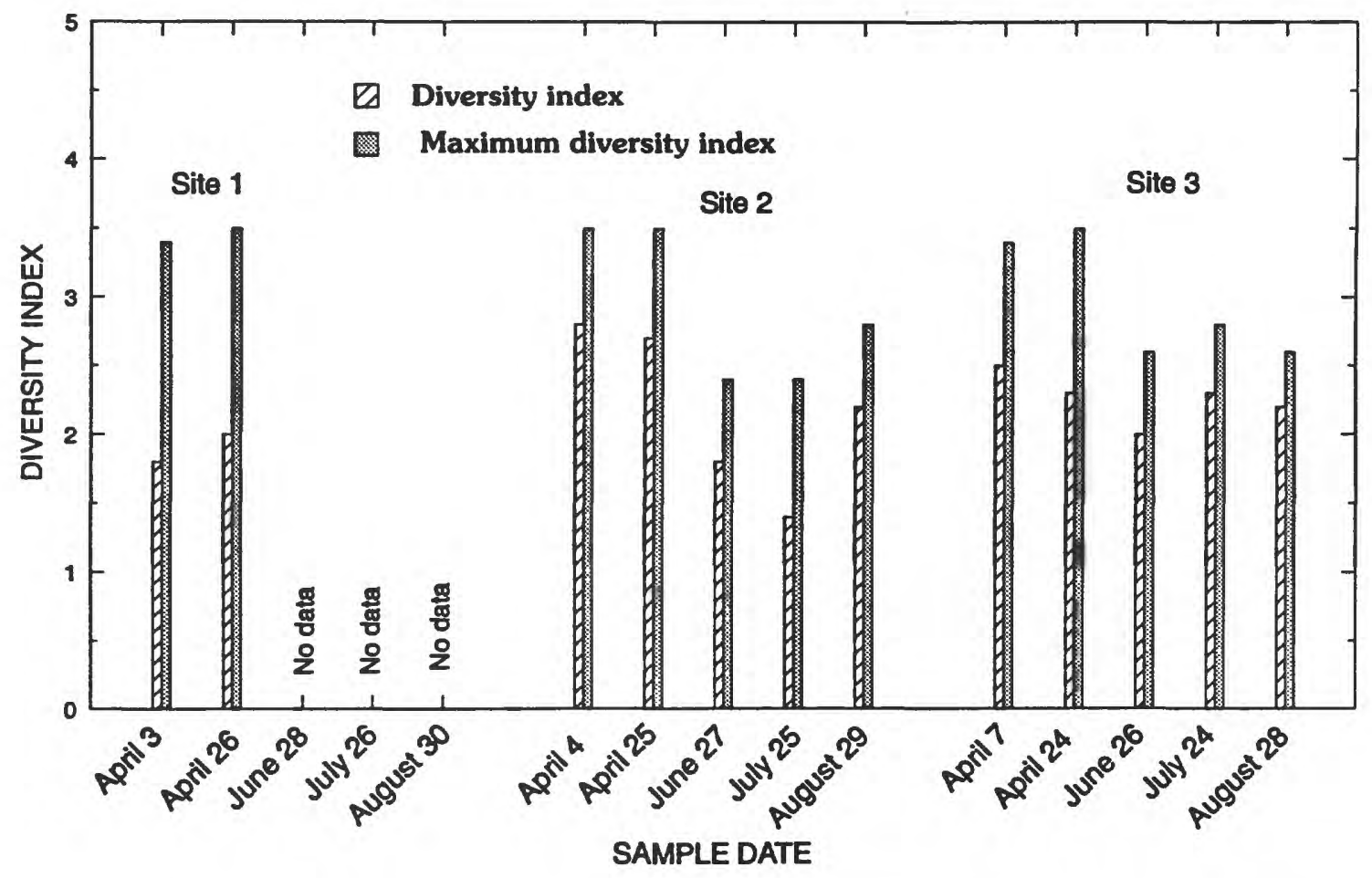

Figure 11. Diversity index and maximum diversity index of periphyton for sites 1-3, lower Olmos Creek and upper San Antonio River, San Antonio, Texas, 1989. 

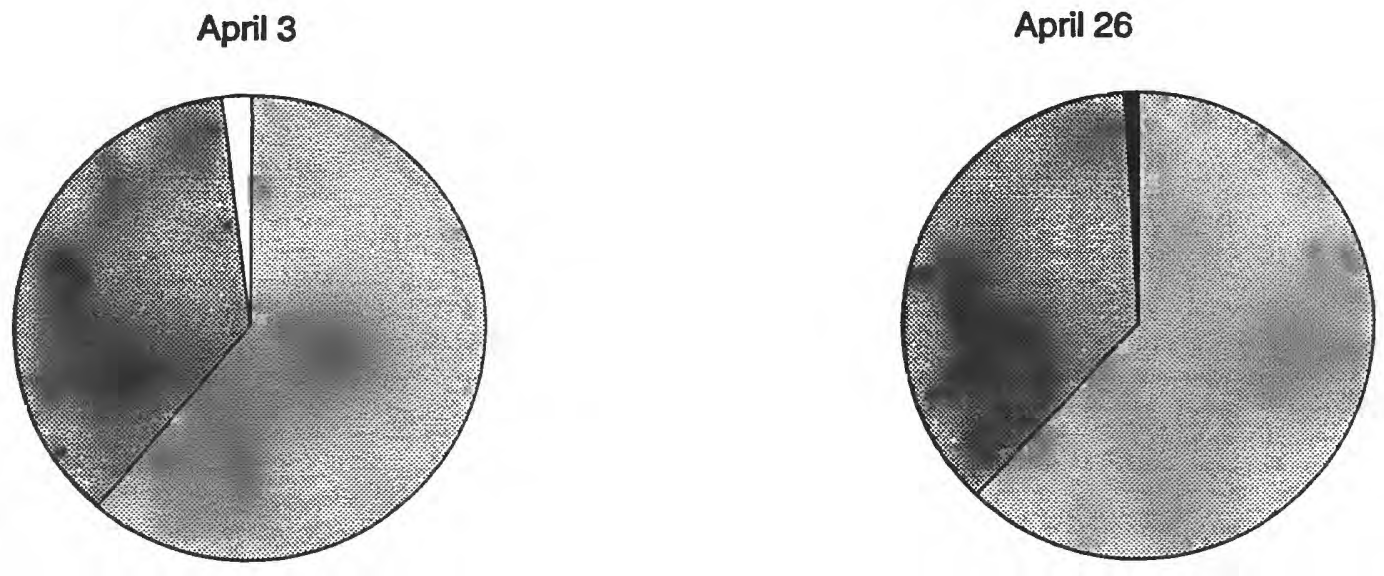

\section{Explanation \\ Cyanophyta \\ Chlorophyta \\ Bacillariophyta \\ Sum of classes that individually compose less than 1 percent of the total}

Figure 12. Periphyton divisions for site 1, lower Olmos Creek, San Antonio, Texas, 1989.

site 3. Sites 1 and 3 had the largest dissolved nitrite concentrations, ranging from 0.027 to $0.038 \mathrm{mg} / \mathrm{L}$. Most of the nitrite plus nitrate nitrogen was in the dissolved state. Dissolved ammonia nitrogen generally was less than $0.100 \mathrm{mg} / \mathrm{L}$; however, site 1 had a concentration of $0.132 \mathrm{mg} / \mathrm{L}$ on April 3. The total phosphorus concentration at site 1 on April 3 was 0.150 $\mathrm{mg} / \mathrm{L}$, more than one-half of which was dissolved orthophosphate. Sites 2 and 3 had total phosphorus concentrations of less than $0.050 \mathrm{mg} / \mathrm{L}$, and in most samples, dissolved orthophosphate was more than onehalf of the phosphorus.

Water samples were analyzed for 14 trace elements, most of which were near or less than reporting thresholds. Total aluminum and total iron concentrations were the exceptions at all three sites. Total aluminum concentrations ranged from 70 to $280 \mu \mathrm{g} /$, and total iron concentrations ranged from 70 to $340 \mu \mathrm{g} / \mathrm{L}$.

Fine bottom-material samples were analyzed for seven trace elements. Most concentrations of trace elements in bottom-material samples were larger than the reporting thresholds. The most prominent was lead, with concentrations ranging from 30 to $70 \mu \mathrm{g} / \mathrm{g}$ at sites 1 and 2 and as much as $230 \mu \mathrm{g} / \mathrm{g}$ at site 3 .
Fine bottom-material samples also were collected to determine particle-size distribution. Particlesize distribution of the fine material collected from pooled areas at sites 1-3 are shown in figure 21. Samples were collected during the first sampling period at site 1 and during the first and last sampling periods at sites 2 and 3.

\section{REFERENCES CITED}

Averett, R.C., 1981, Species diversity and its measurement, in Greeson, P.E., ed., Biota and biological parameters as environmental indicators (Briefing papers on water quality): U.S. Geological Survey Circular 848-B, p. B3-B6.

Britton, L.J., and Greeson, P.E., eds., 1988, Methods for collection and analysis of aquatic biological and microbiological samples: U.S. Geological Survey Techniques of Water-Resources Investigations, book 5, chap. A4, $363 \mathrm{p}$.

Caims, John, Jr., and Dickson, K.L., 1971, A simple method for the biological assessment of the effects of waste discharges on aquatic bottom-dwelling organisms: Journal of the Water Pollution Control Federation, v. 43, no. 5 , p. 755-772.

Colby, B.R., 1963, Fluvial sediments-a summary of source, transportation, deposition, and measurement of 

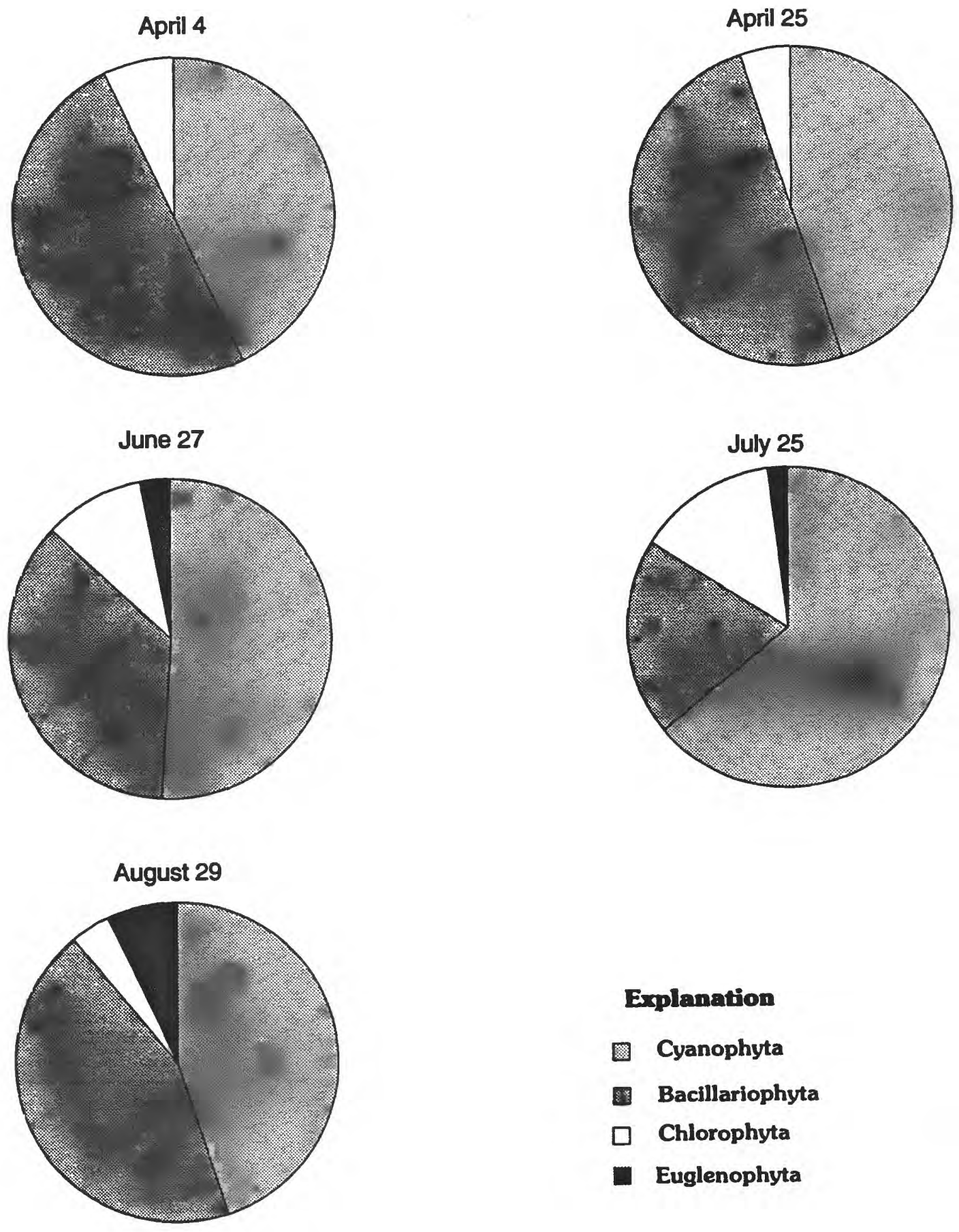

\section{Explanation}

Cyanophyta

Bacillariophyta

$\square$ Chlorophyta

- Euglenophyta

Figure 13. Periphyton divisions for site 2, upper San Antonio River, San Antonio, Texas, 1989. 

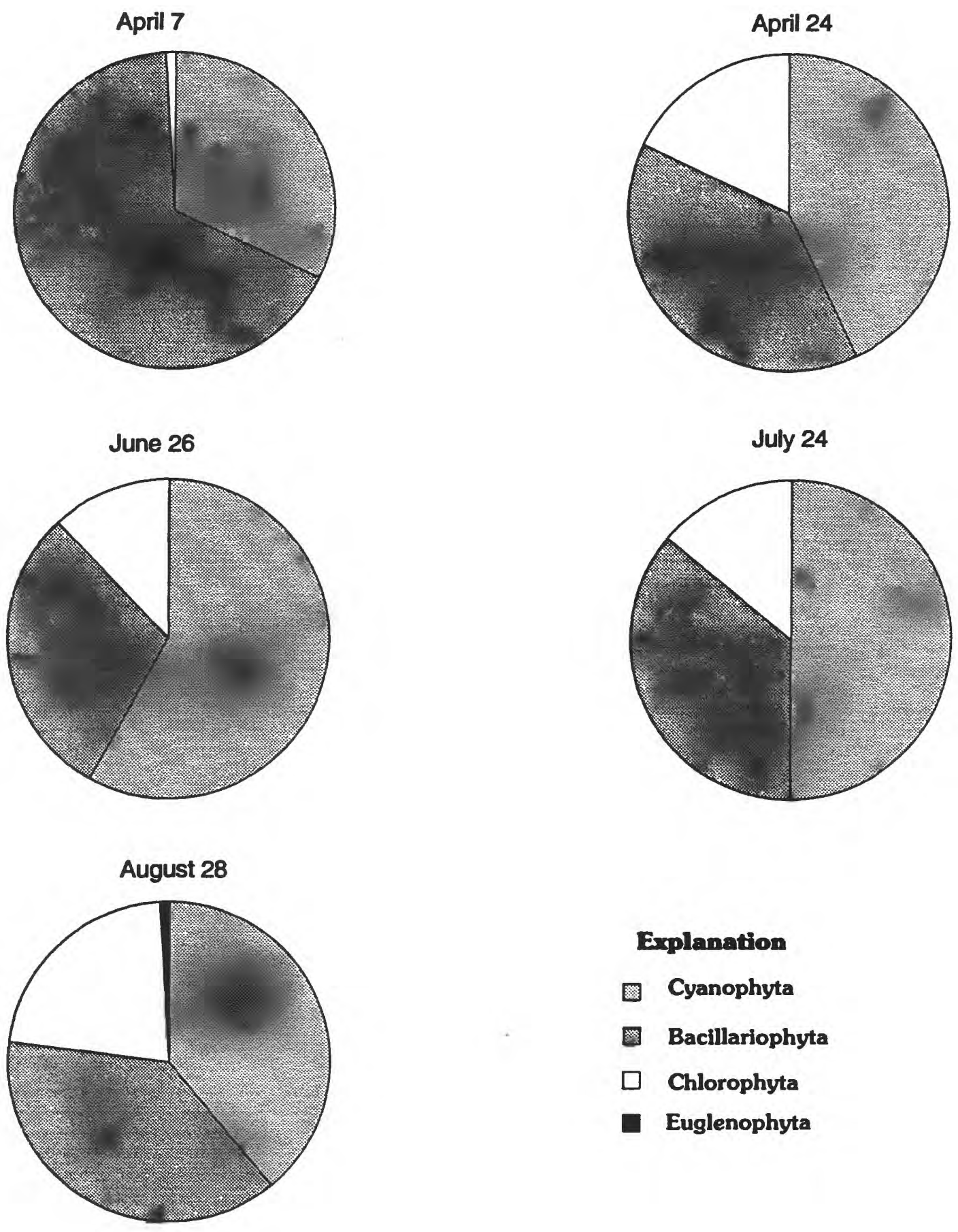

\section{Explanation}

Cyanophyta

Bacillariophyta

$\square$ Chlorophyta

- Euglenophyta

Figure 14. Periphyton divisions for site 3, upper San Antonio River, San Antonio, Texas, 1989. 


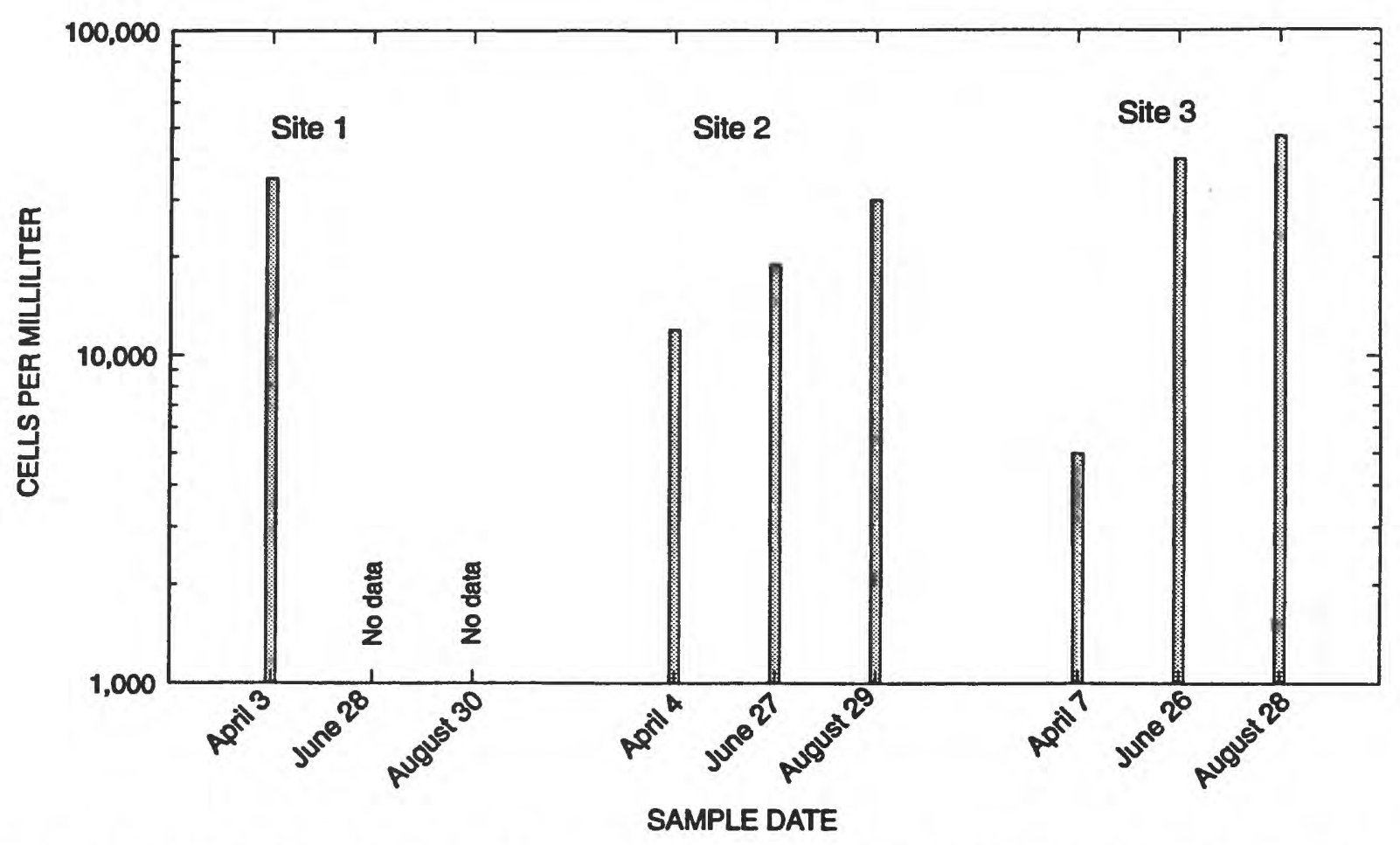

Figure 15. Total density of phytoplankton for sites 1-3, lower Olmos Creek and upper San Antonio River, San Antonio, Texas, 1989.

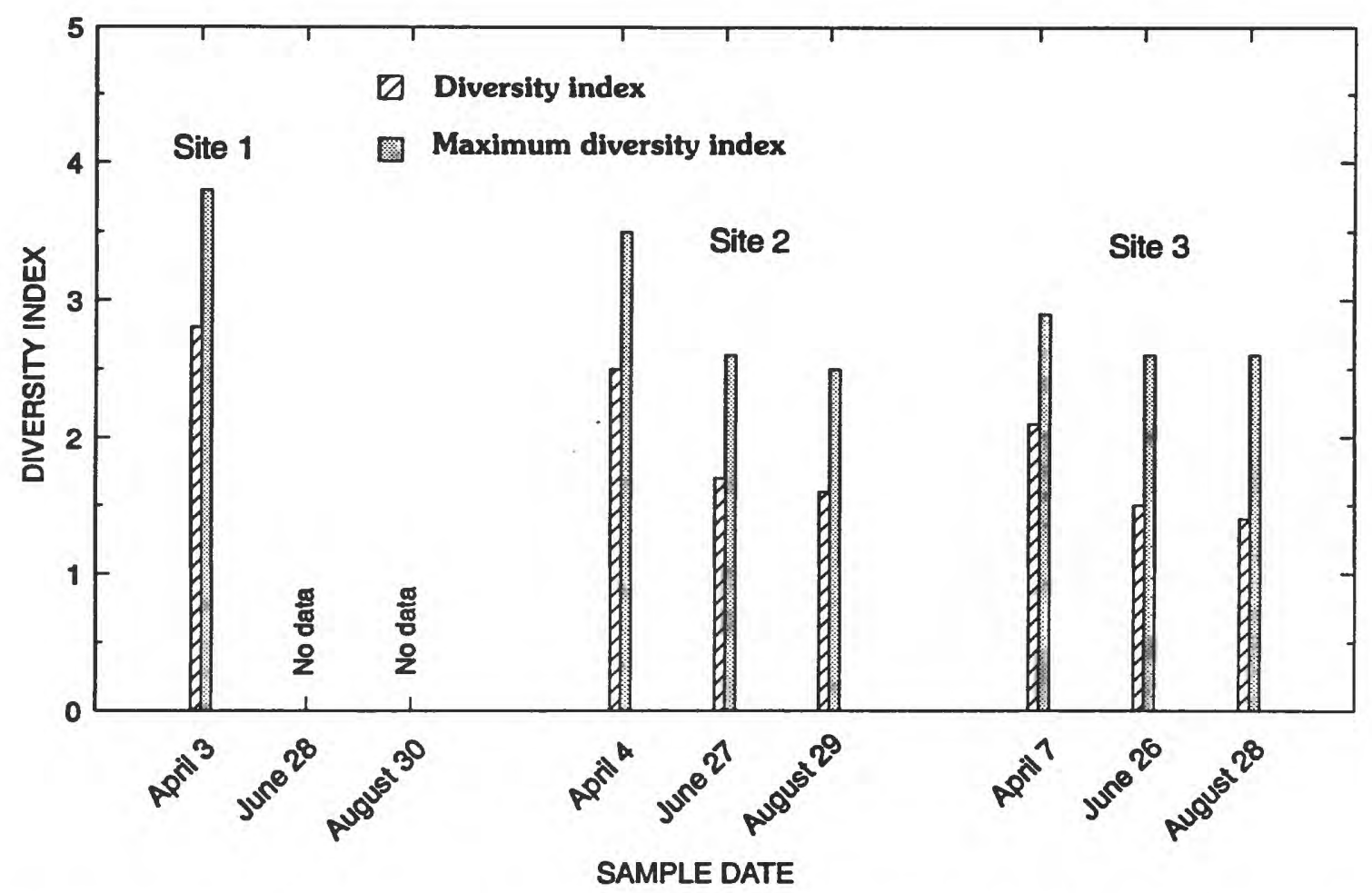

Figure 16. Diversity index and maximum diversity index of phytoplankton for sites 1-3, lower Olmos Creek and upper San Antonio River, San Antonio, Texas, 1989. 


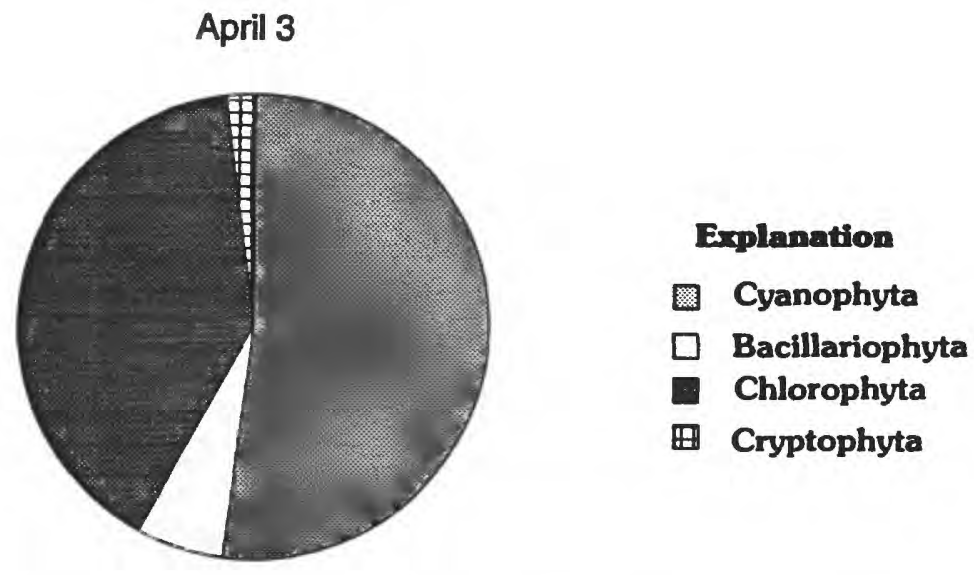

Figure 17. Phytoplankton divisions for site 1, lower Olmos Creek, San Antonio, Texas, 1989.
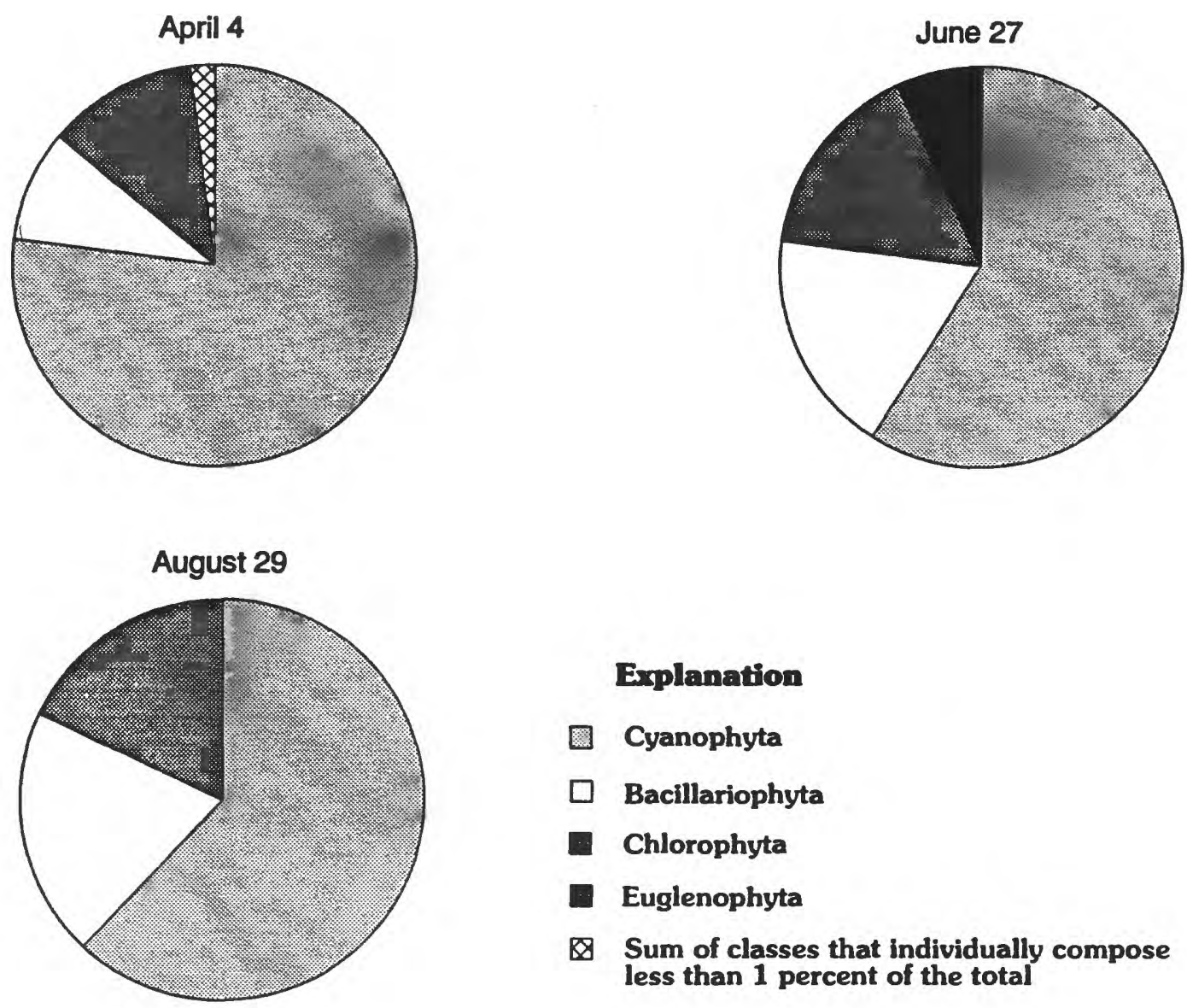

Figure 18. Phytoplankton divisions for site 2, upper San Antonio River, San Antonio, Texas, 1989.

20 Biological and Associated Water-Quality Data for Lower Olmos Creek and Upper San Antonio River, San Antonio, Texas, April-September 1989 


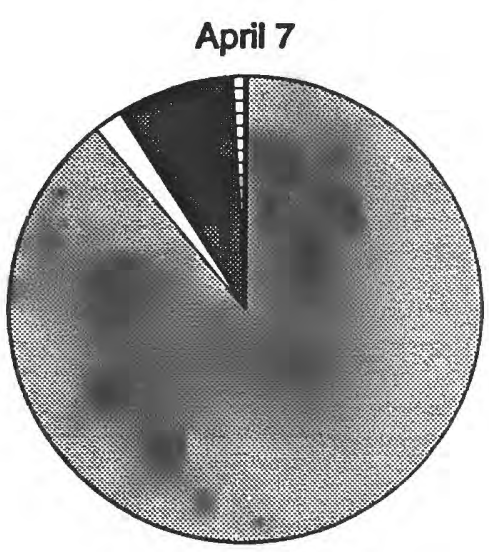

August 28

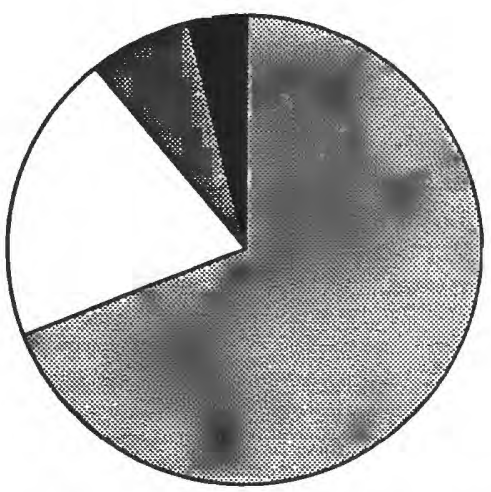

June 26

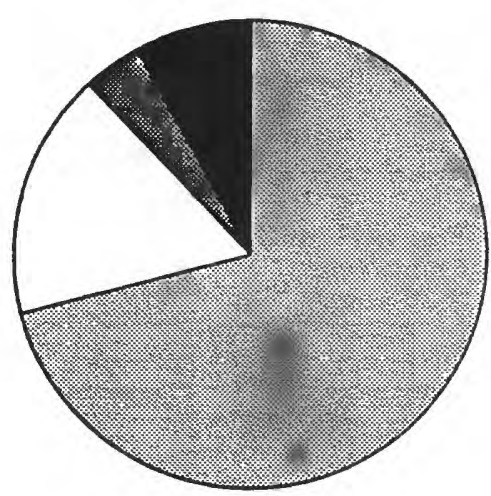

\section{Explanation}

Cyanophyta
$\square$ Bacillariophyta
Chlorophyta
Euglenophyta
Cryptophyta

Figure 19. Phytoplankton divisions for site 3, upper San Antonio River, San Antonio, Texas, 1989.

sediment discharge, in Contributions to general geology: U.S. Geological Survey Bulletin 118-A, p. A1-A47.

Cummins, K.W., 1974, Structure and function of stream ecosystems: Bioscience, v. 24, p. 631-641.

Frenzel, S.A., 1988, Physical, chemical, and biological characteristics of the Boise River from Veterans Memorial Parkway, Boise to Star, Idaho, October 1987 to March 1988: U.S. Geological Survey Water-Resources Investigations Report 88-4206, 48 p.

Goodnight, C.J., 1973, The use of aquatic macroinvertebrates as indicators of stream pollution: Transactions of the American Microscopical Society, v. 92, no. 1, p. 1-13.

Guy, H.P., 1969, Laboratory theory and methods for sediment analysis: U.S. Geological Survey Techniques of Water-Resources Investigations, book 5, chap. C1, $58 \mathrm{p}$.

Guy, H.P., and Norman, V.W., 1970, Field methods for measurement of fluvial sediment: U.S. Geological Survey Techniques of Water-Resources Investigations, book 3 , chap. C2, 59 p.
Horowitz, A.J., 1984, A primer on trace metal-sediment chemistry: U.S. Geological Survey Open-File Report 84-709, 82 p.

Hynes, H.B.N., 1970, The ecology of running waters: Liverpool, Liverpool University Press, 555 p.

Shannon, C.E., and Weaver, Warren, 1949, The mathematical theory of communication: Urbana, Ill., University of Illinois Press, $177 \mathrm{p}$.

Smoot, G.F., and Novak, C.E., 1968, Calibration and maintenance of vertical-axis type current meters: U.S. Geological Survey Techniques of Water-Resources Investigations, book 8, chap. B2, 15 p.

Wells, F.C., Gibbons, W.J., and Dorsey, M.D., 1990, Guidelines for collection and field analysis of water-quality samples from streams in Texas: U.S. Geological Survey Open-File Report 90-127, 92 p.

Wetzel, R.G., 1975, Limnology: Philadelphia, W.B. Saunders Co., 743 p.

Wilhm, J.L., and Dorris, T.C., 1968, Biological parameters for water quality criteria: Bioscience, v. 18, no. 6 , p. $477-481$.

Wolman, G.M., 1954, A method of sampling coarse riverbed material: Transactions, American Geophysical Union, v. 35, no. 6, p. 951-956. 

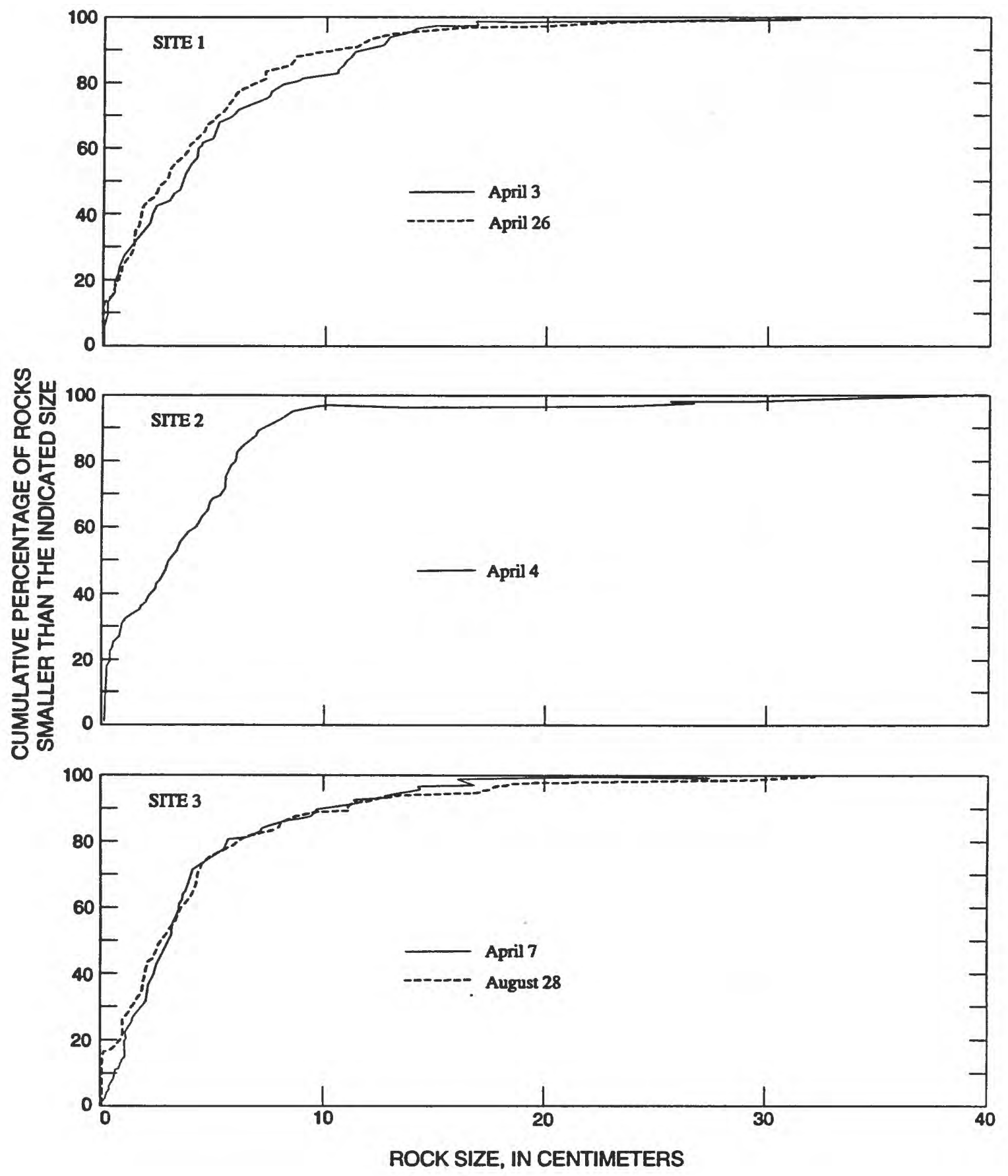

Figure 20. Cumulative-percentage size distribution of bottom material collected from riffles at sites 1-3, lower Olmos Creek and upper San Antonio River, San Antonio, Texas, 1989. 


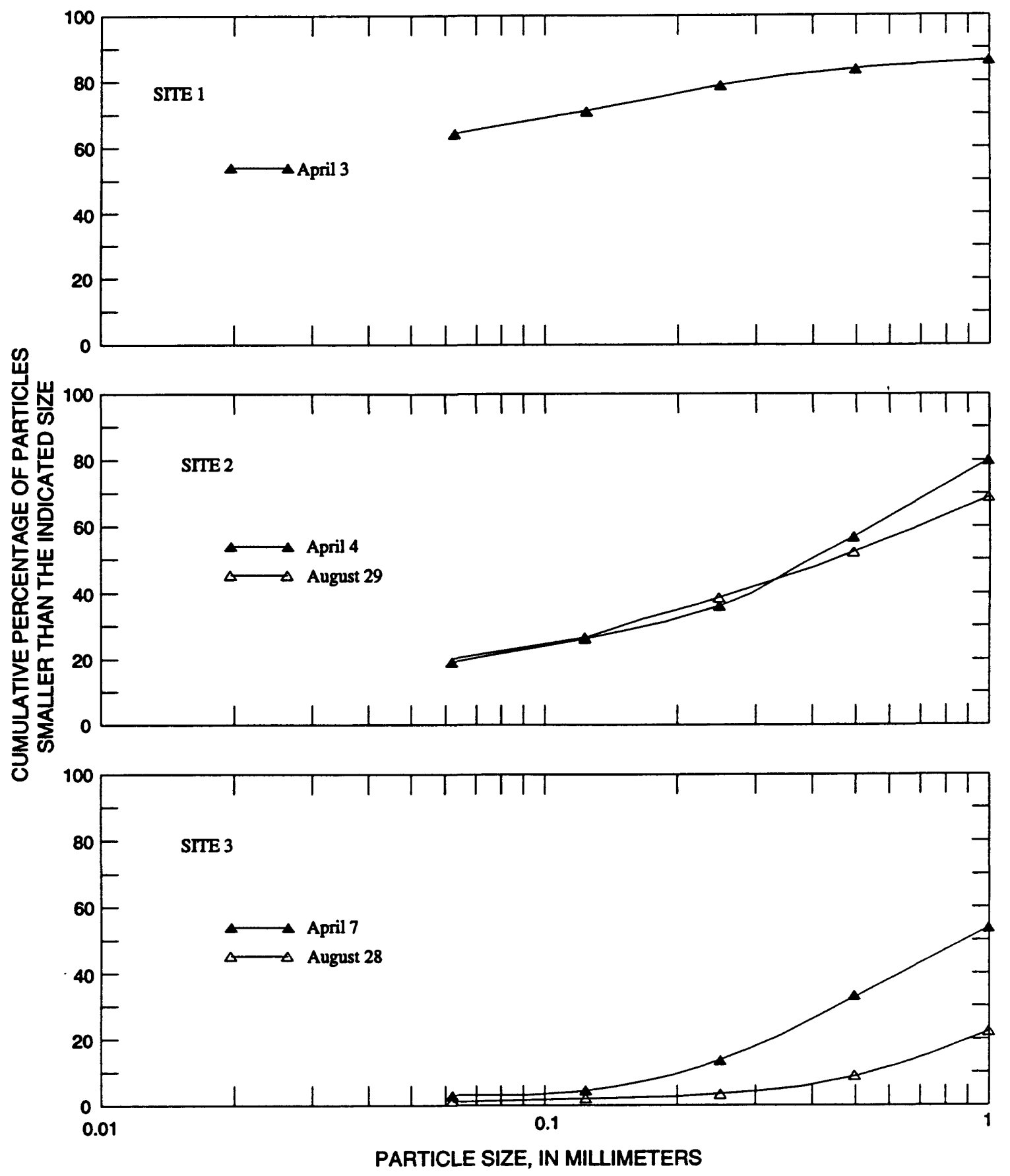

Figure 21. Cumulative-percentage size distribution of bottom material collected from pools at sites 1-3, lower Olmos Creek and upper San Antonio River, San Antonio, Texas, 1989. 


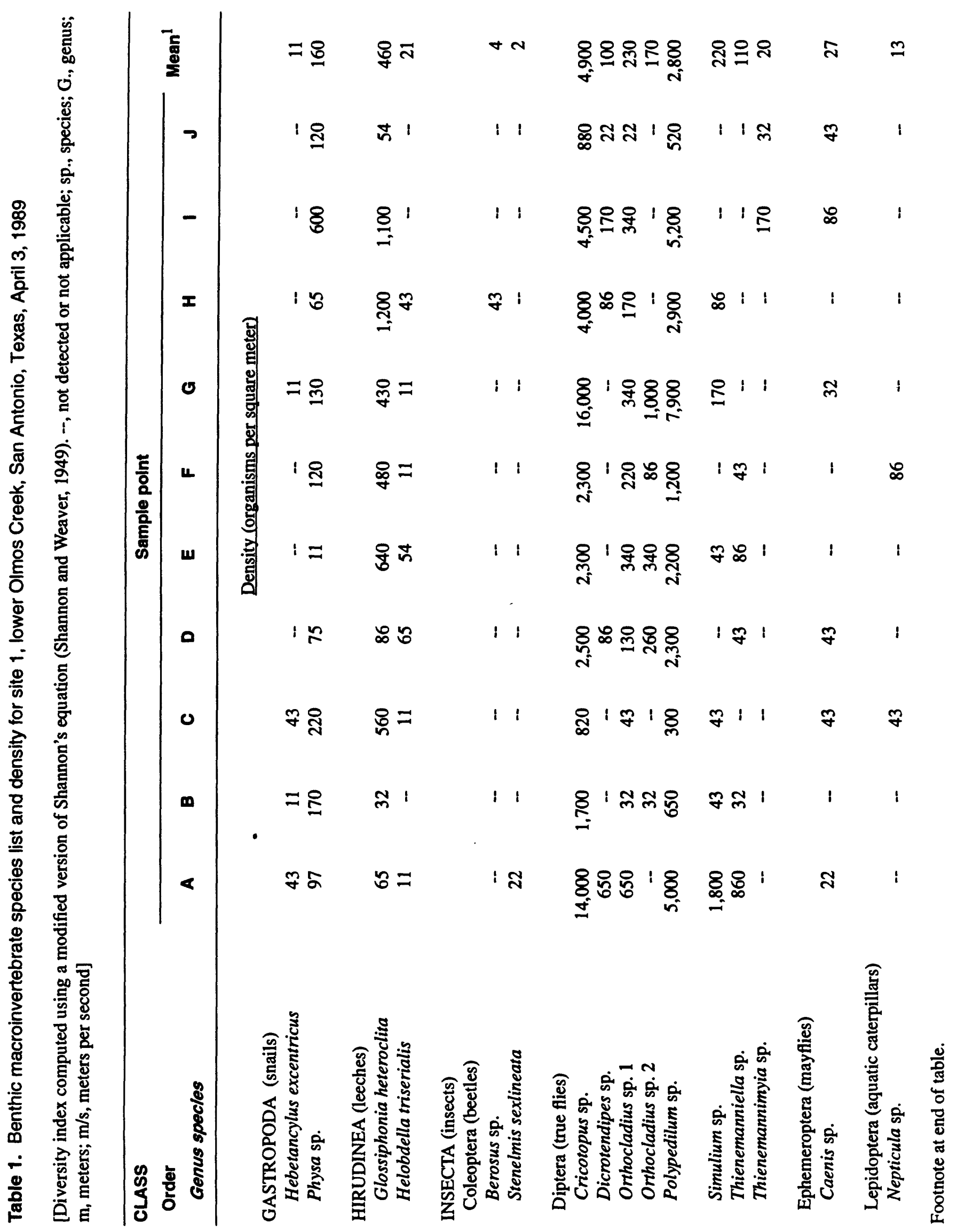

24 Biological and Assoclated Water-Quality Data for Lower Olmos Creek and Upper San Antonio River, San Antonlo, Texas, April-September 1989 


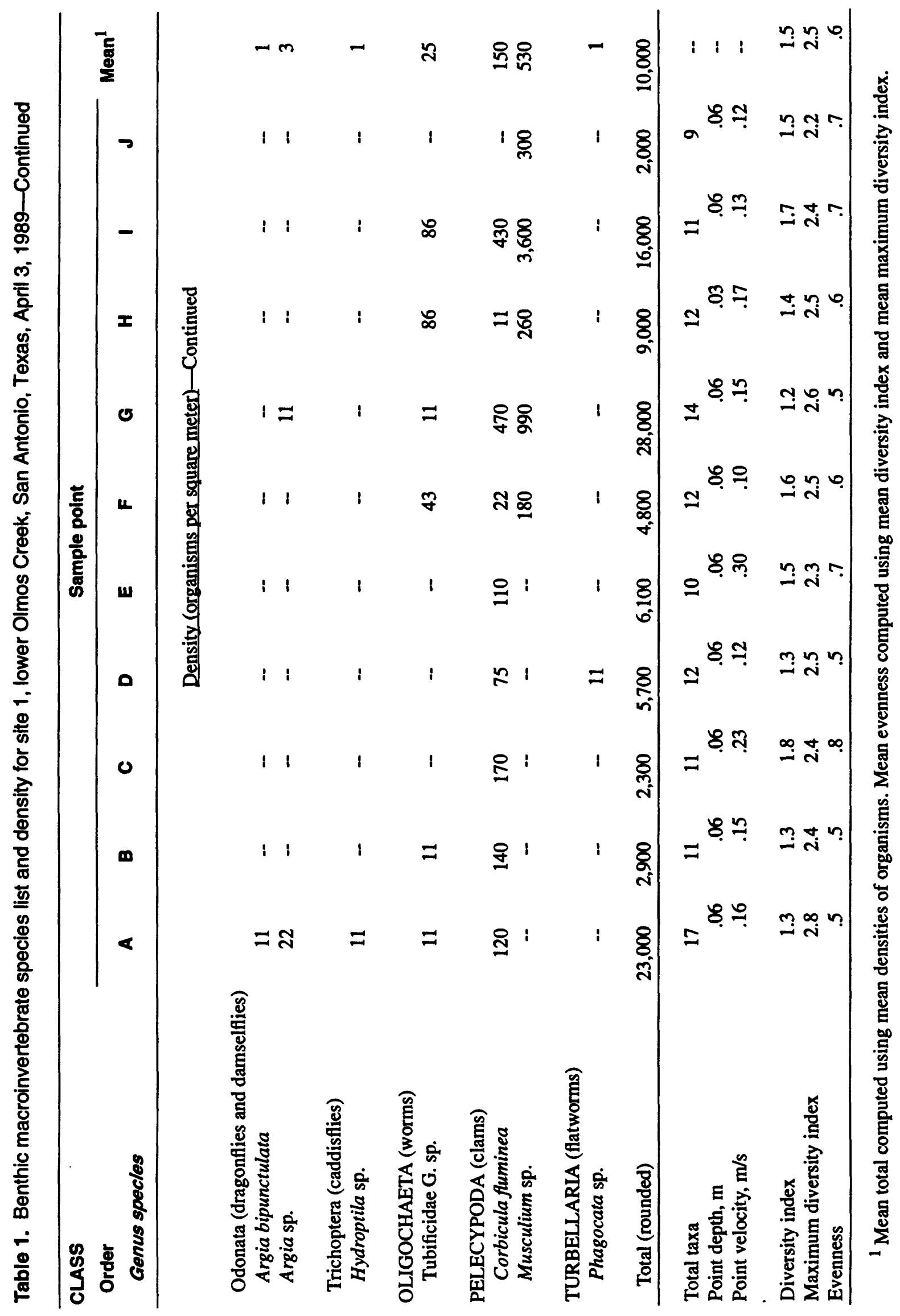




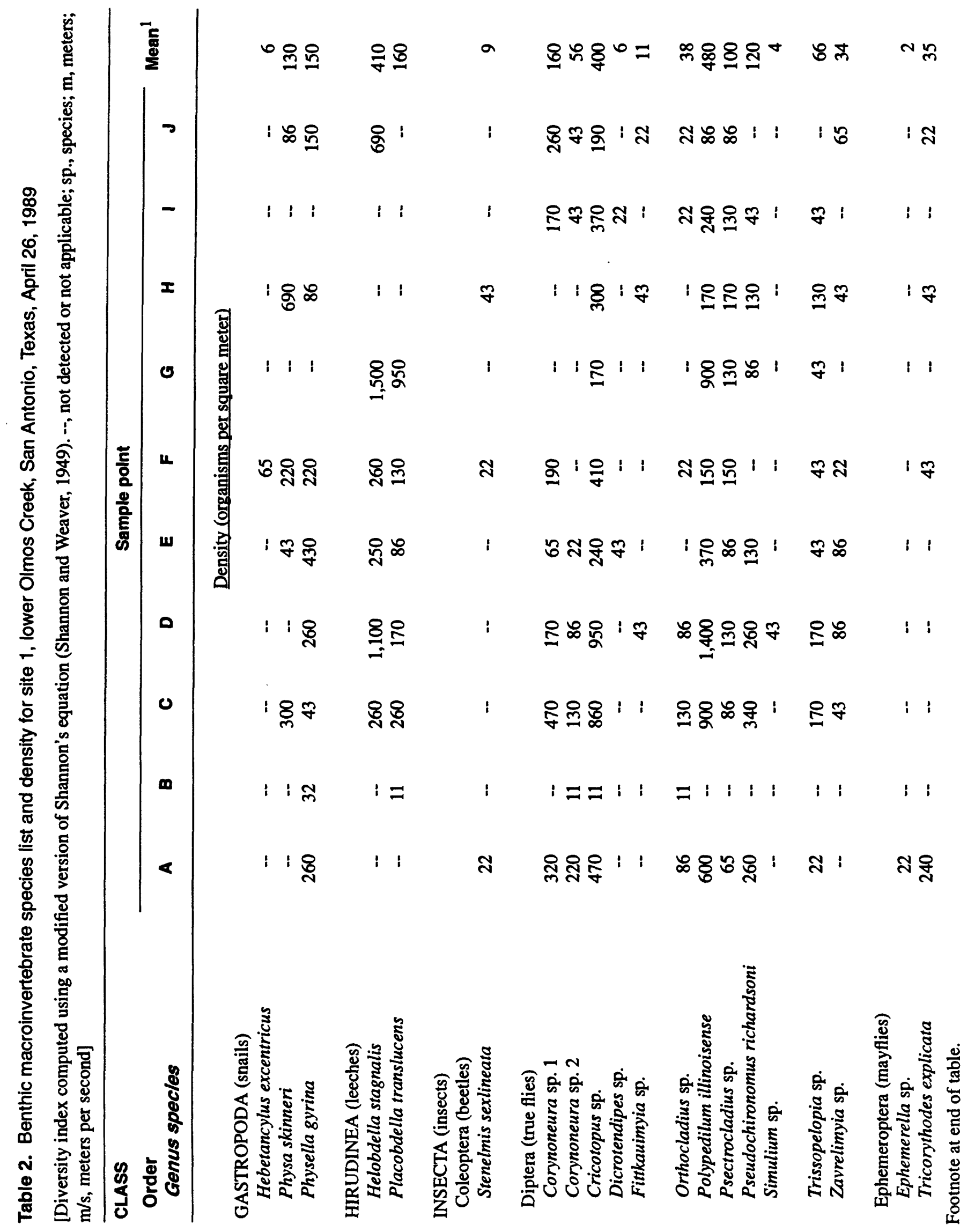

26 Biological and Associated Water-Quality Data for Lower Olmos Creek and Upper San Antonio River, San Antonio, Texas, April-September 1989 


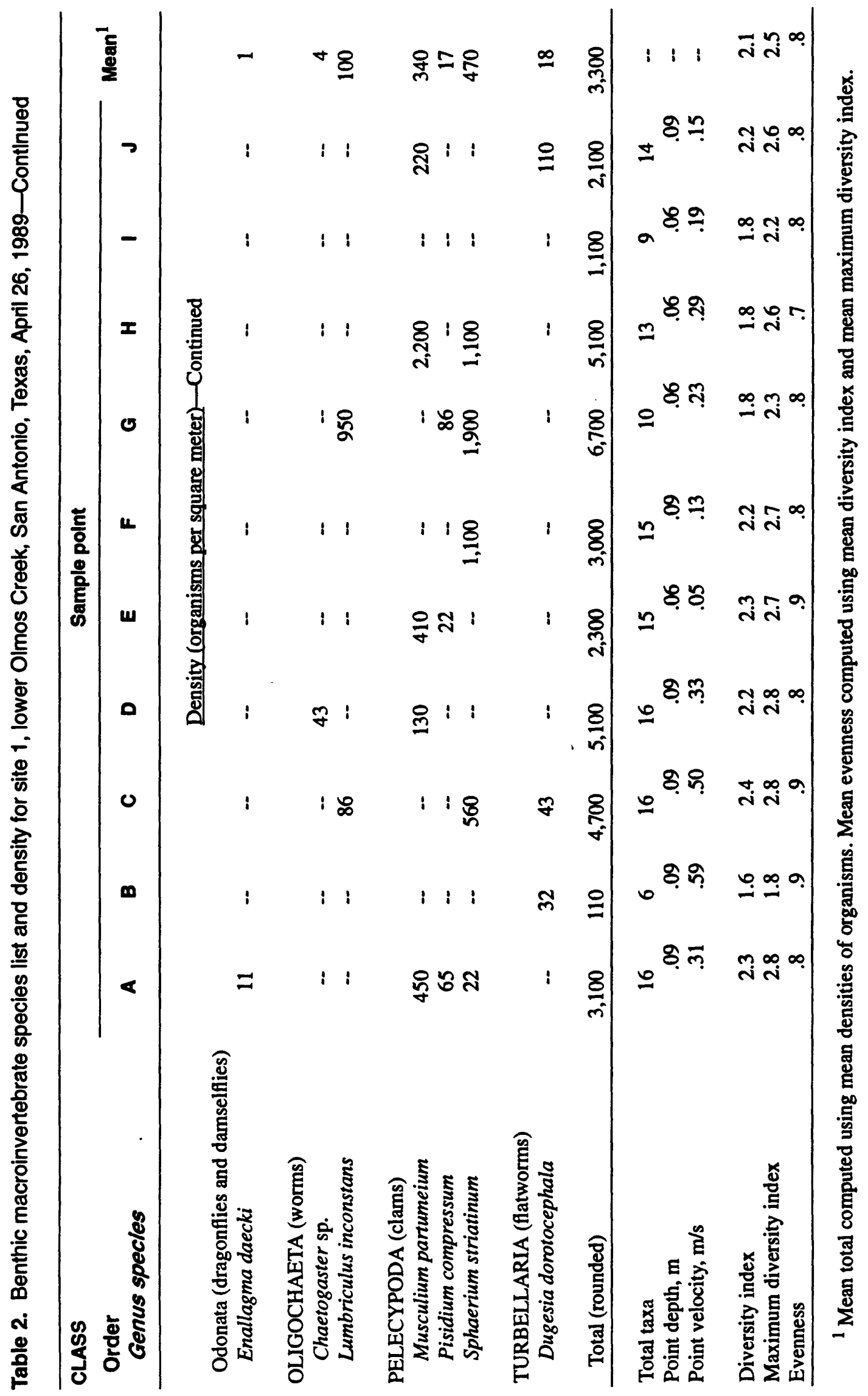




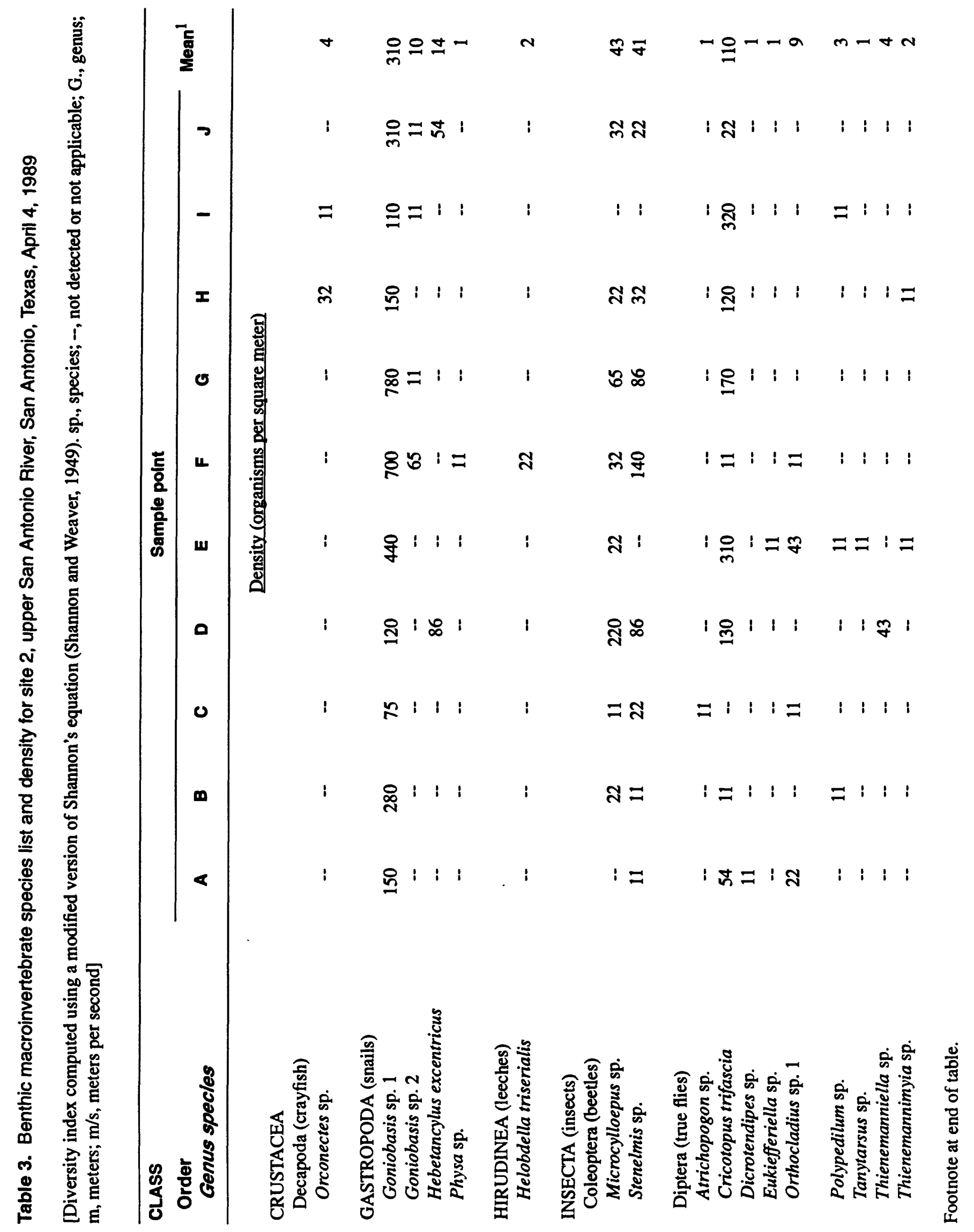

28 Biological and Associated Water-Quality Data for Lower Olmos Creek and Upper San Antonio River, San Antonio, Texas, April-September 1989 


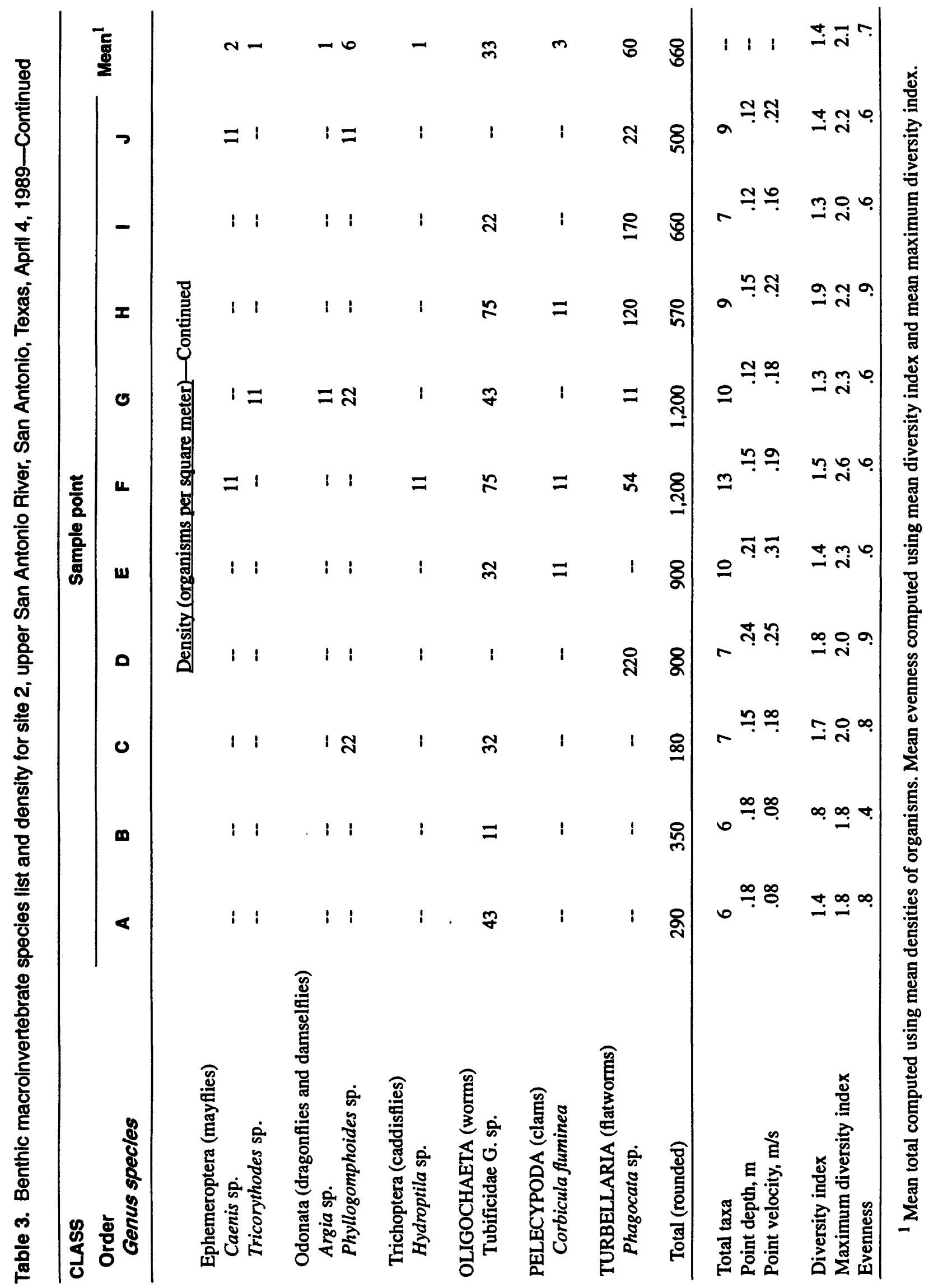




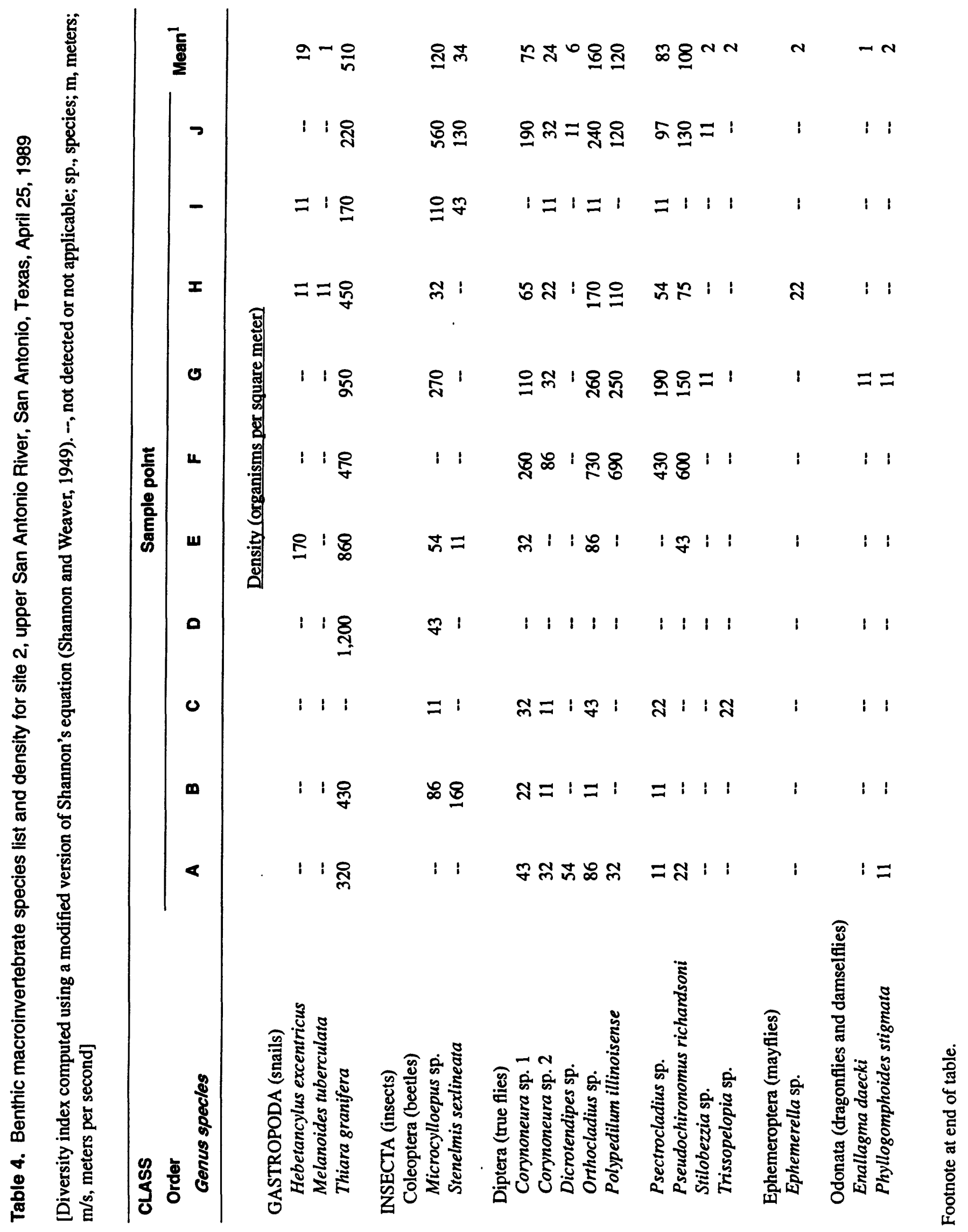

30 Biological and Associated Water-Quality Data for Lower Olmos Creek and Upper San Antonio River, San Antonio, Texas, Apri-September 1989 


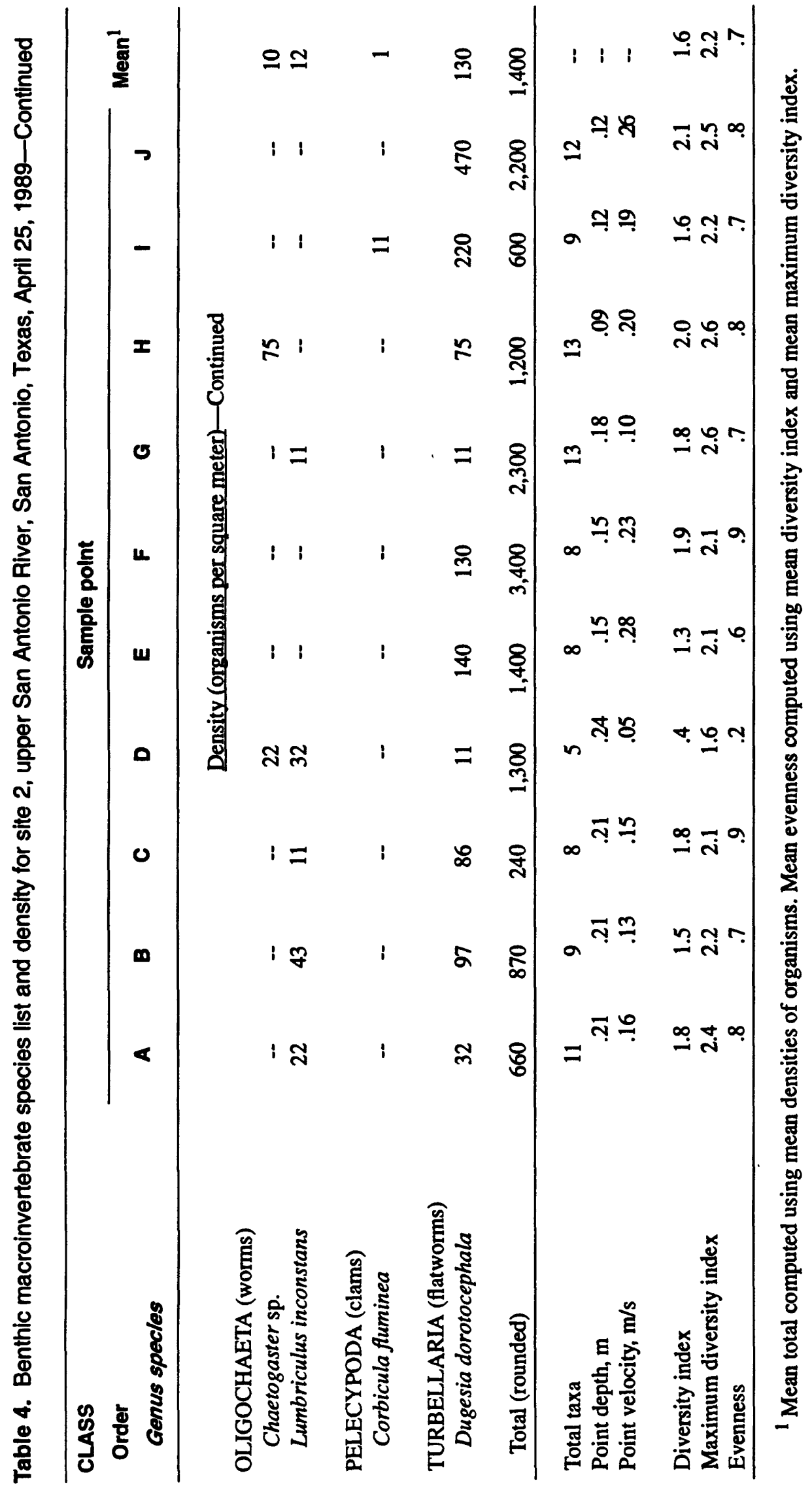




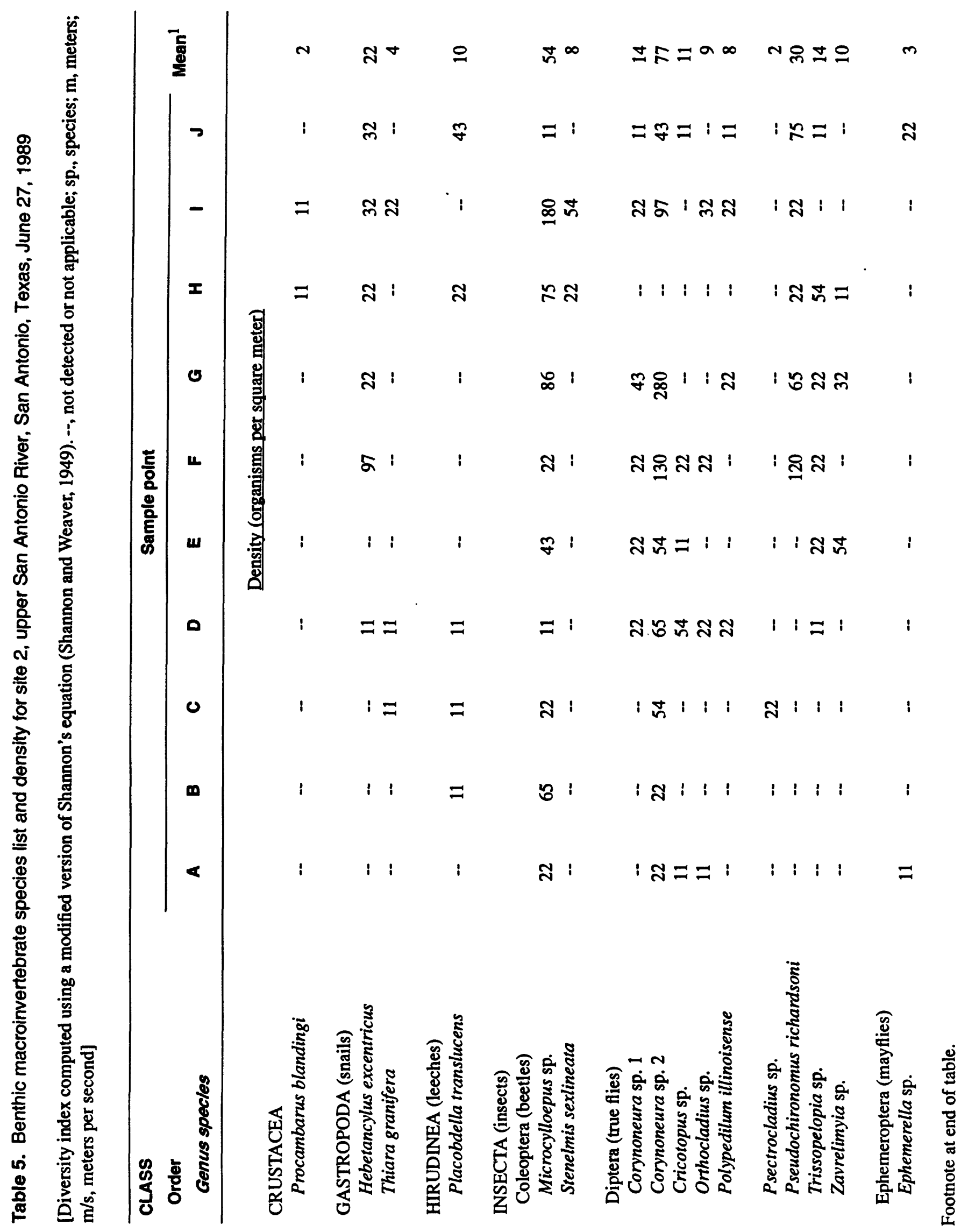




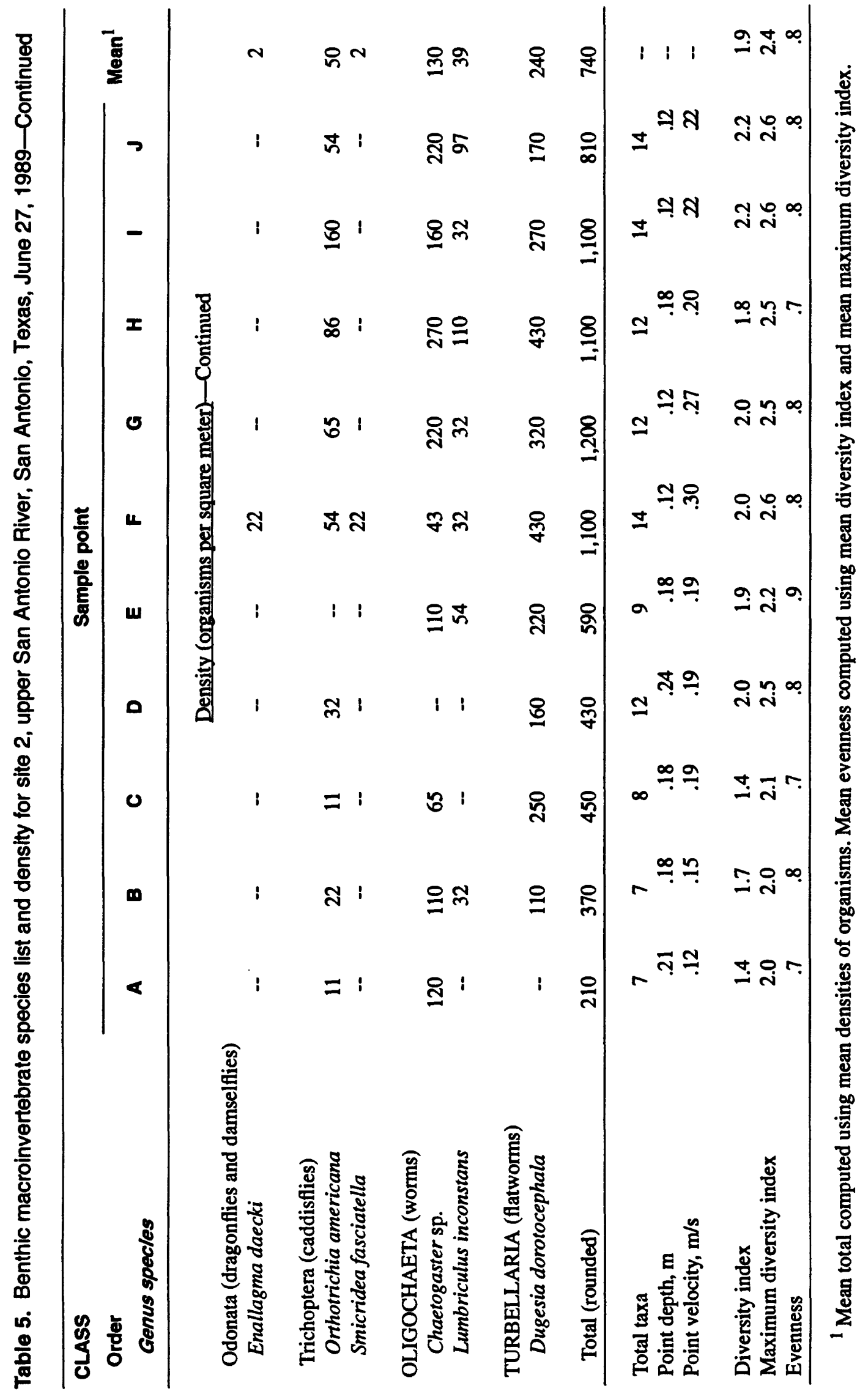




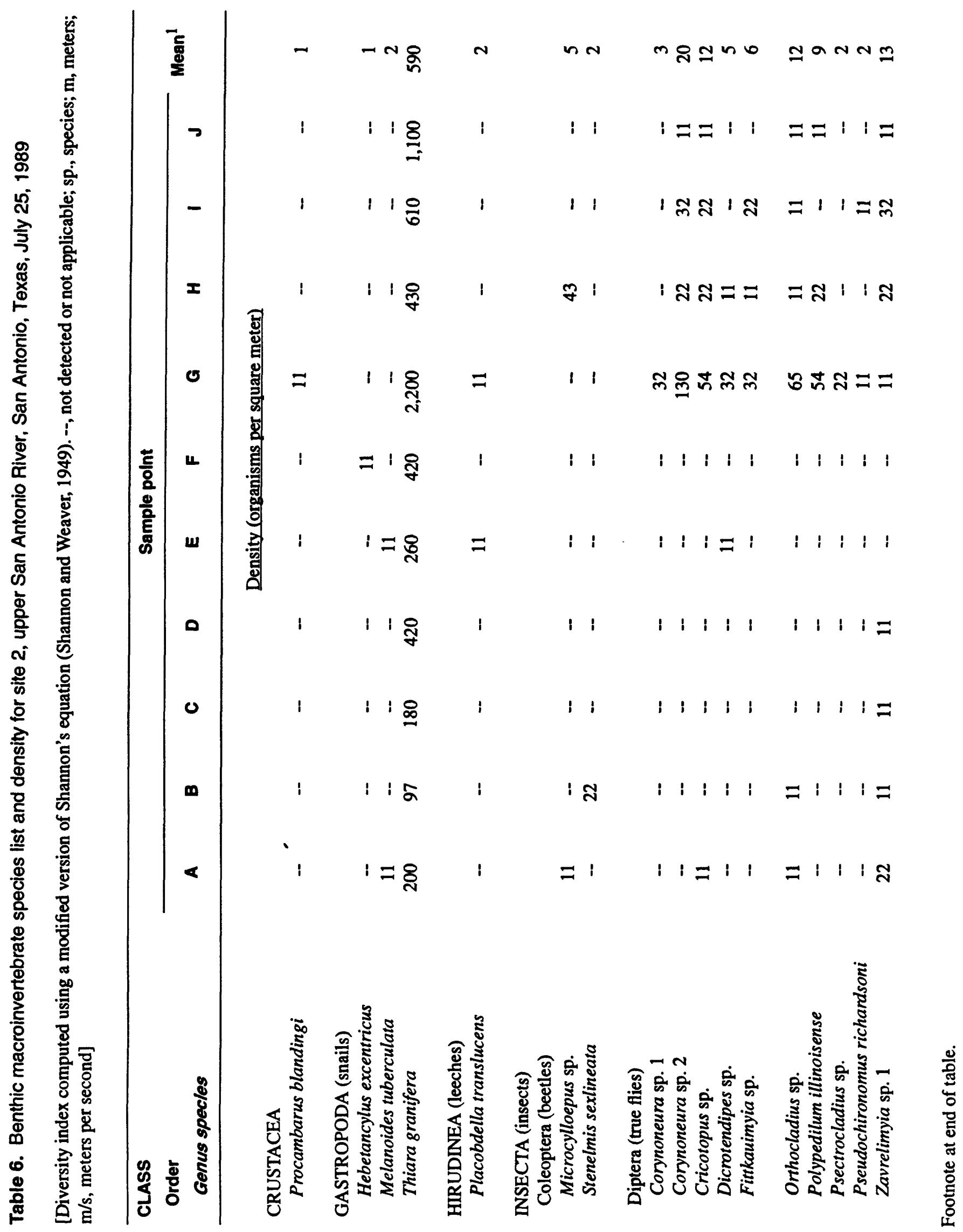

34 Biological and Associated Water-Quaiity Data for Lower Oimos Creek and Upper San Antonio River, San Antonlo, Texas, April-September 1989 


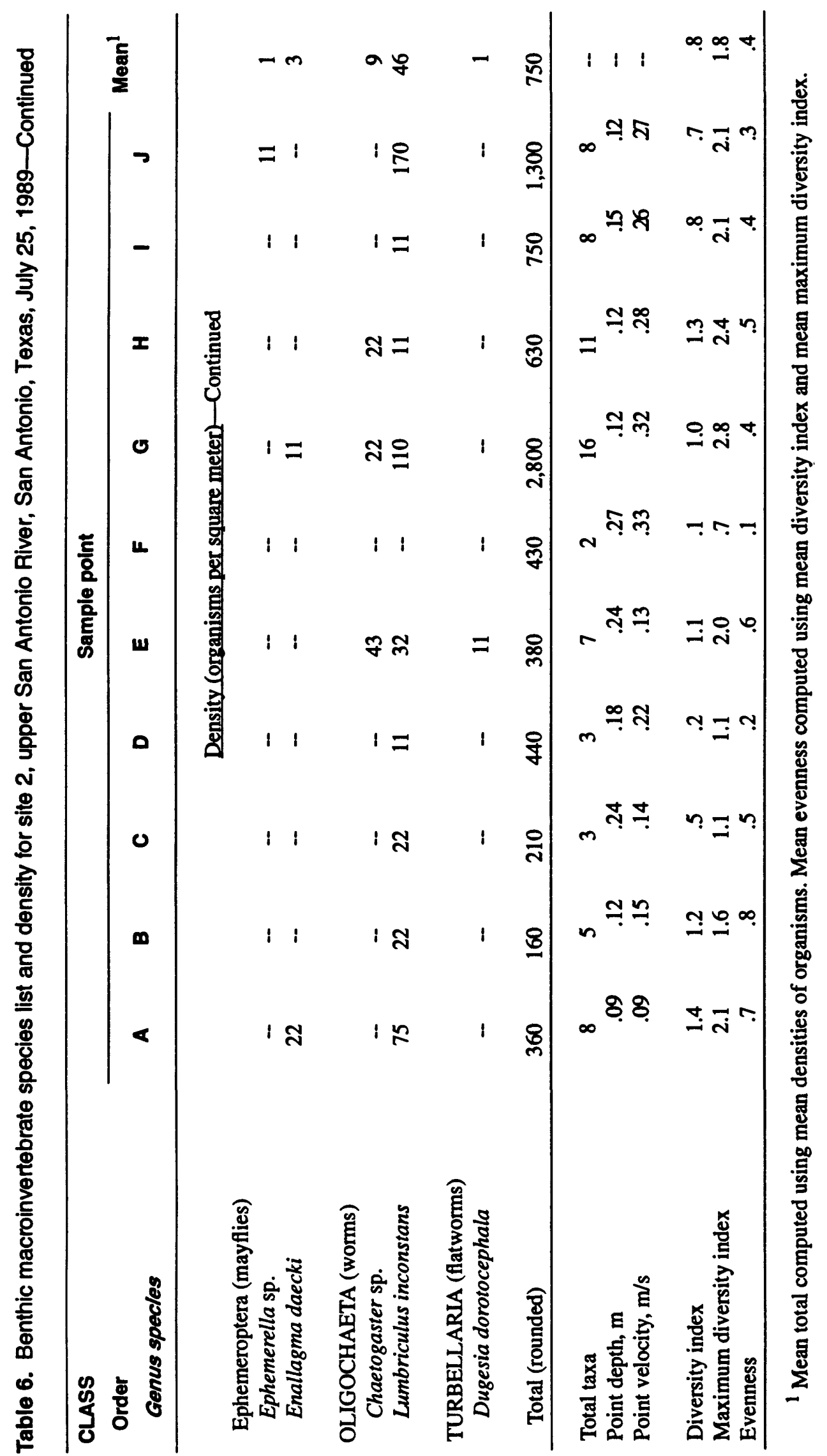




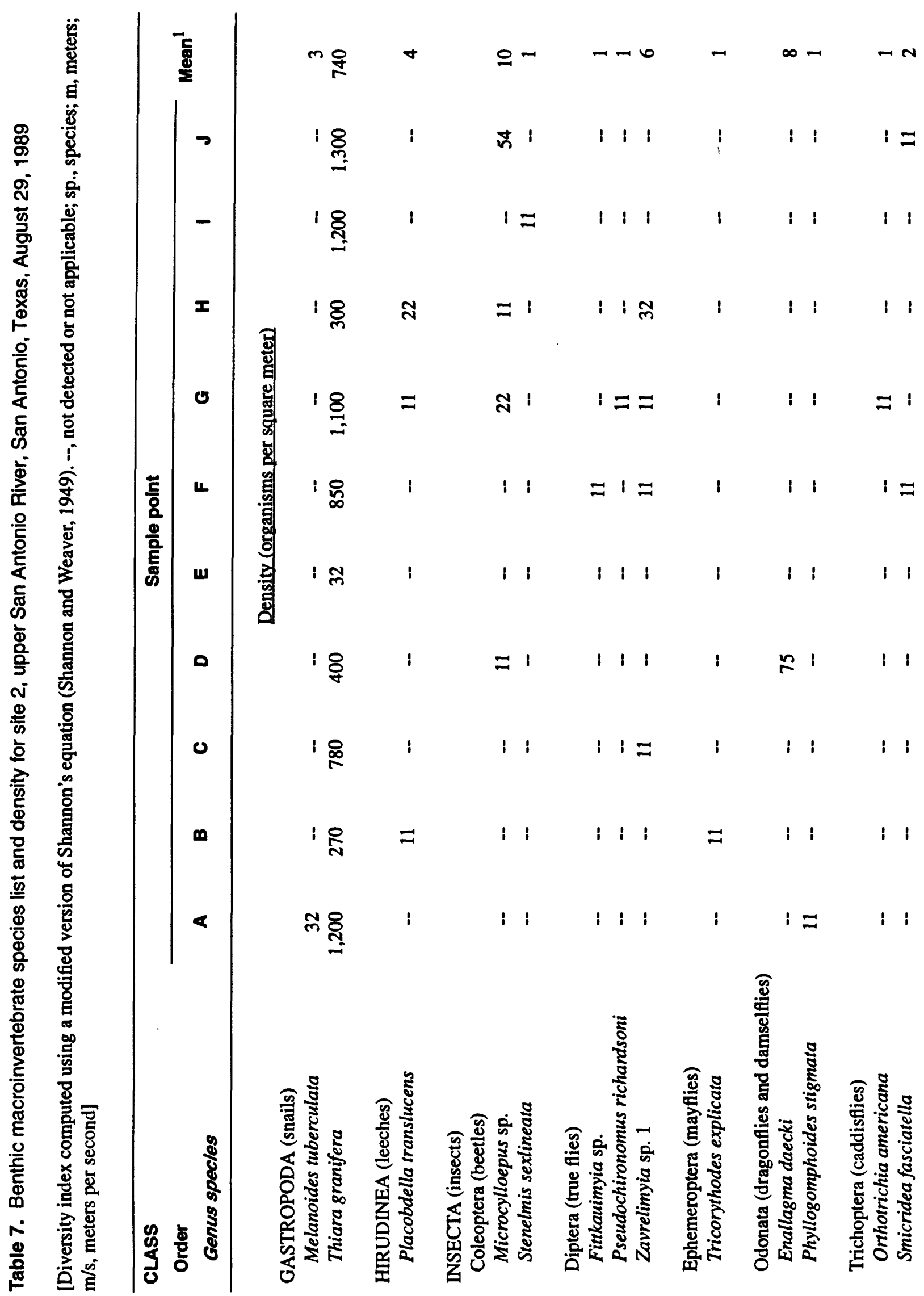

36 Biological and Associated Water-Quality Data for Lower Olmos Creek and Upper San Antonio River, San Antonio, Texas, 


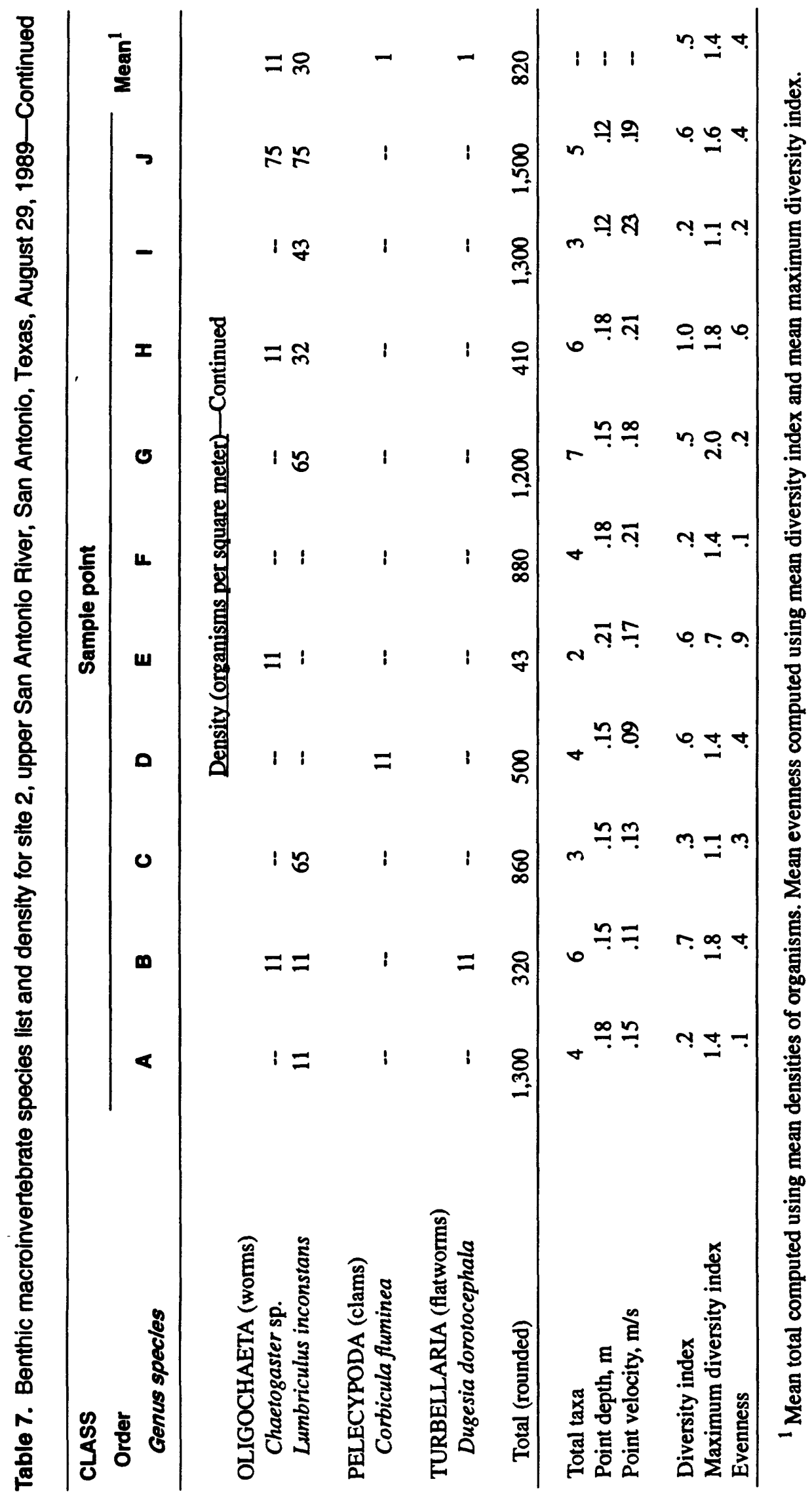




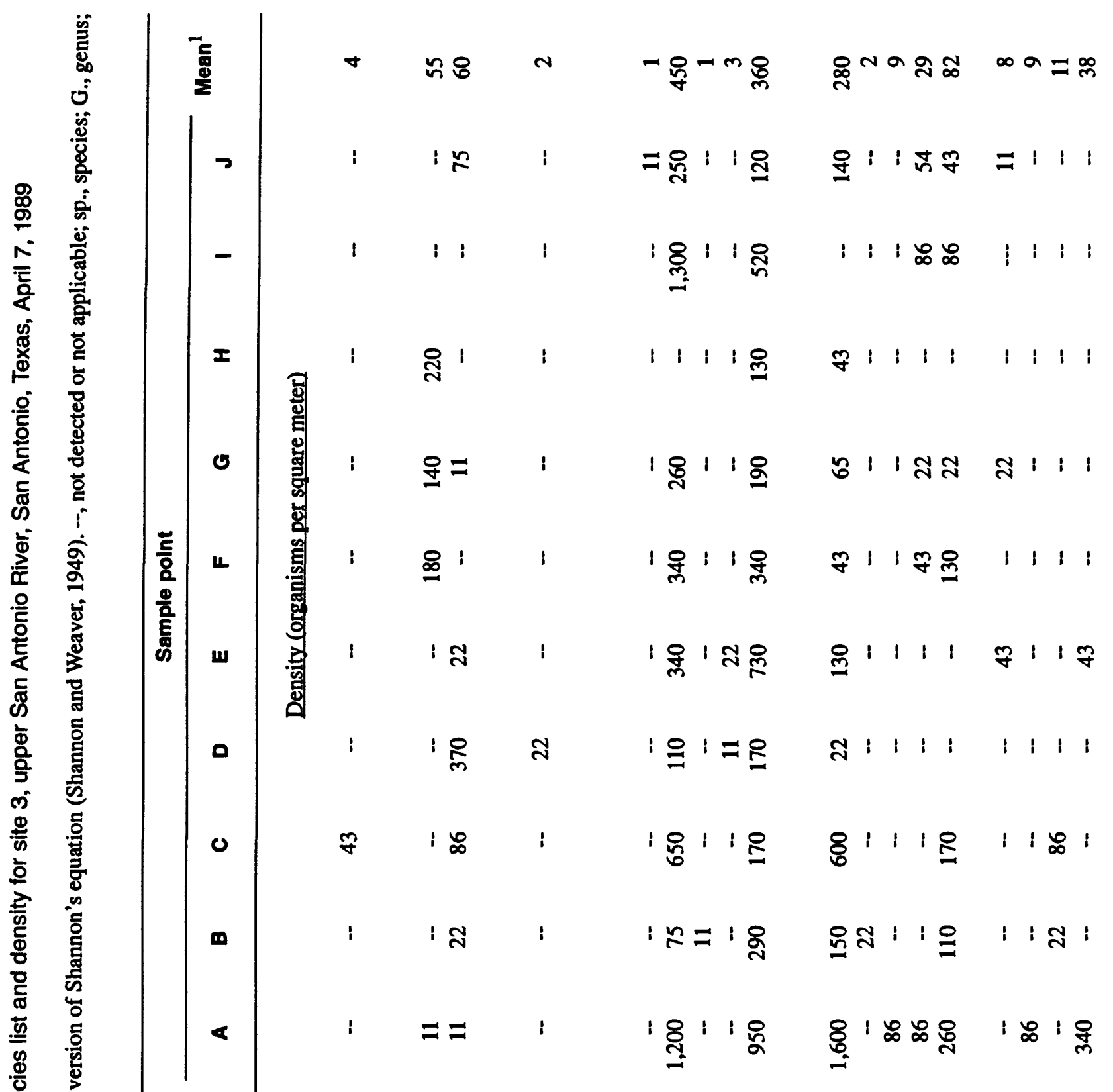
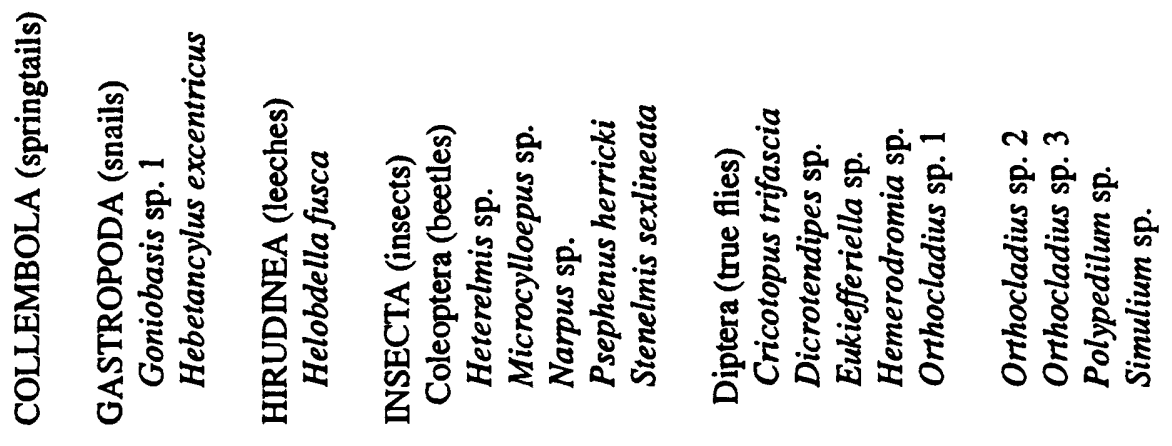


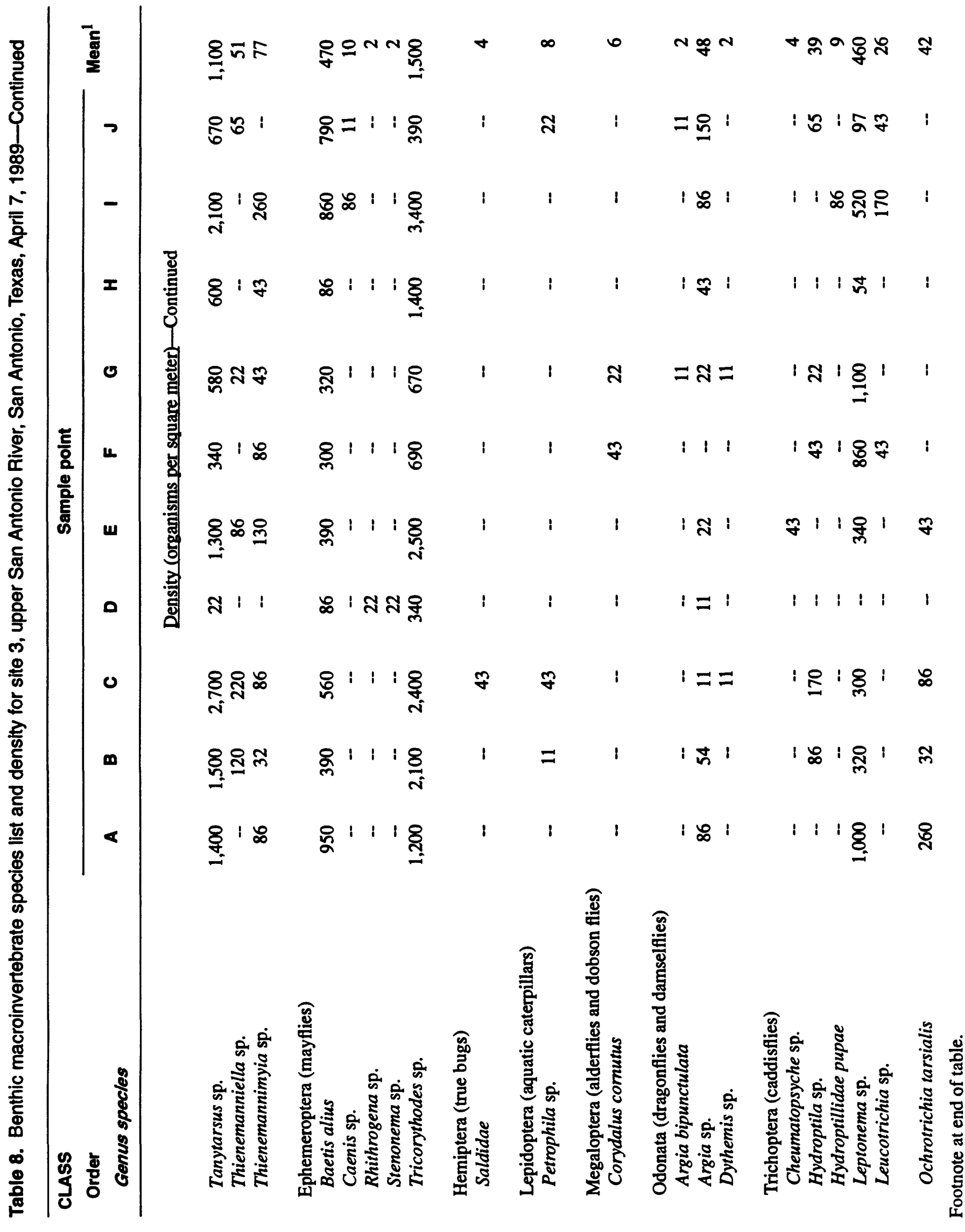




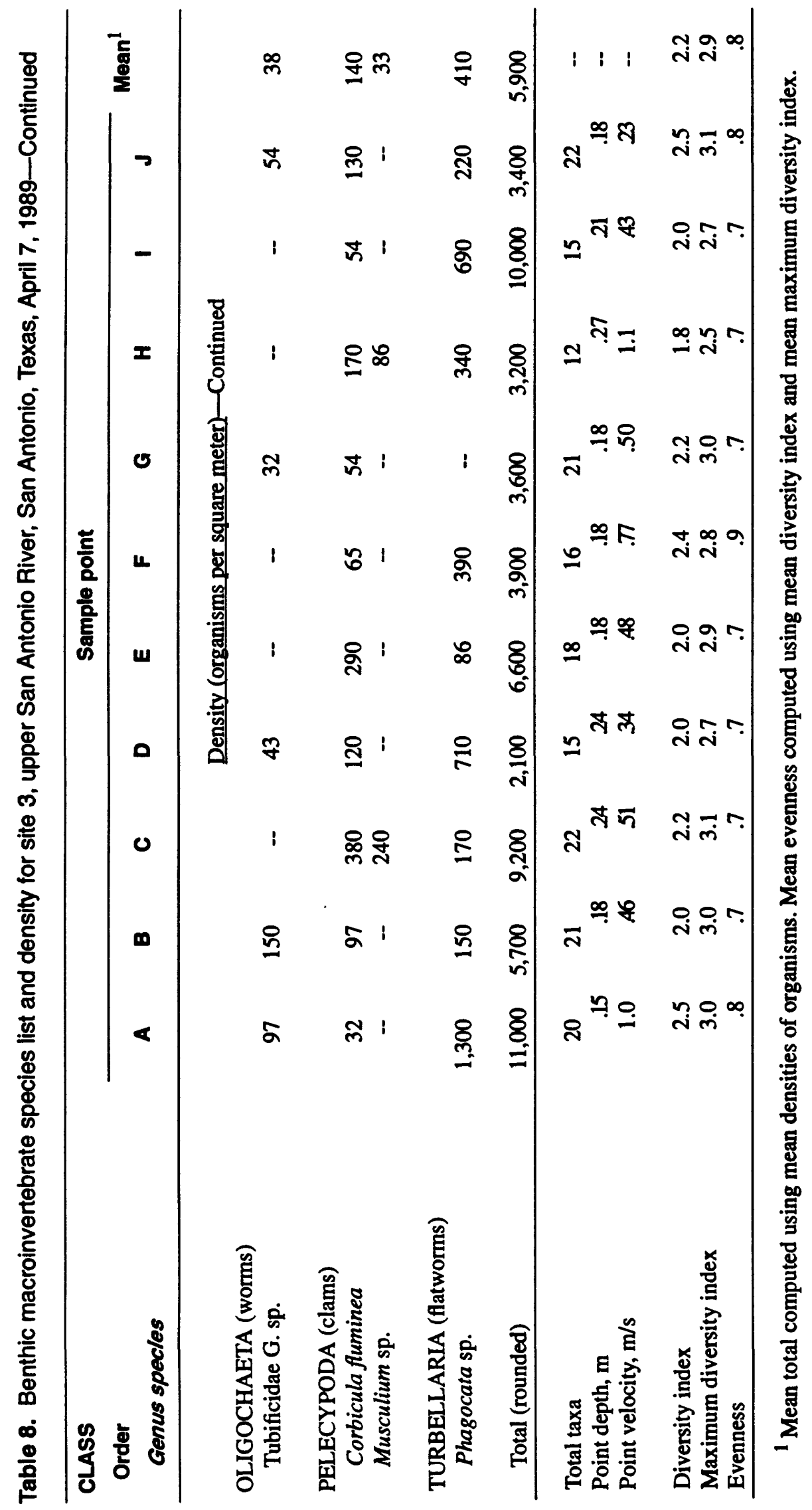

40 Blological and Associated Water-Quality Data for Lower Olmos Creek and Upper San Antonio River, San Antonio, Texas, April-September 1989 


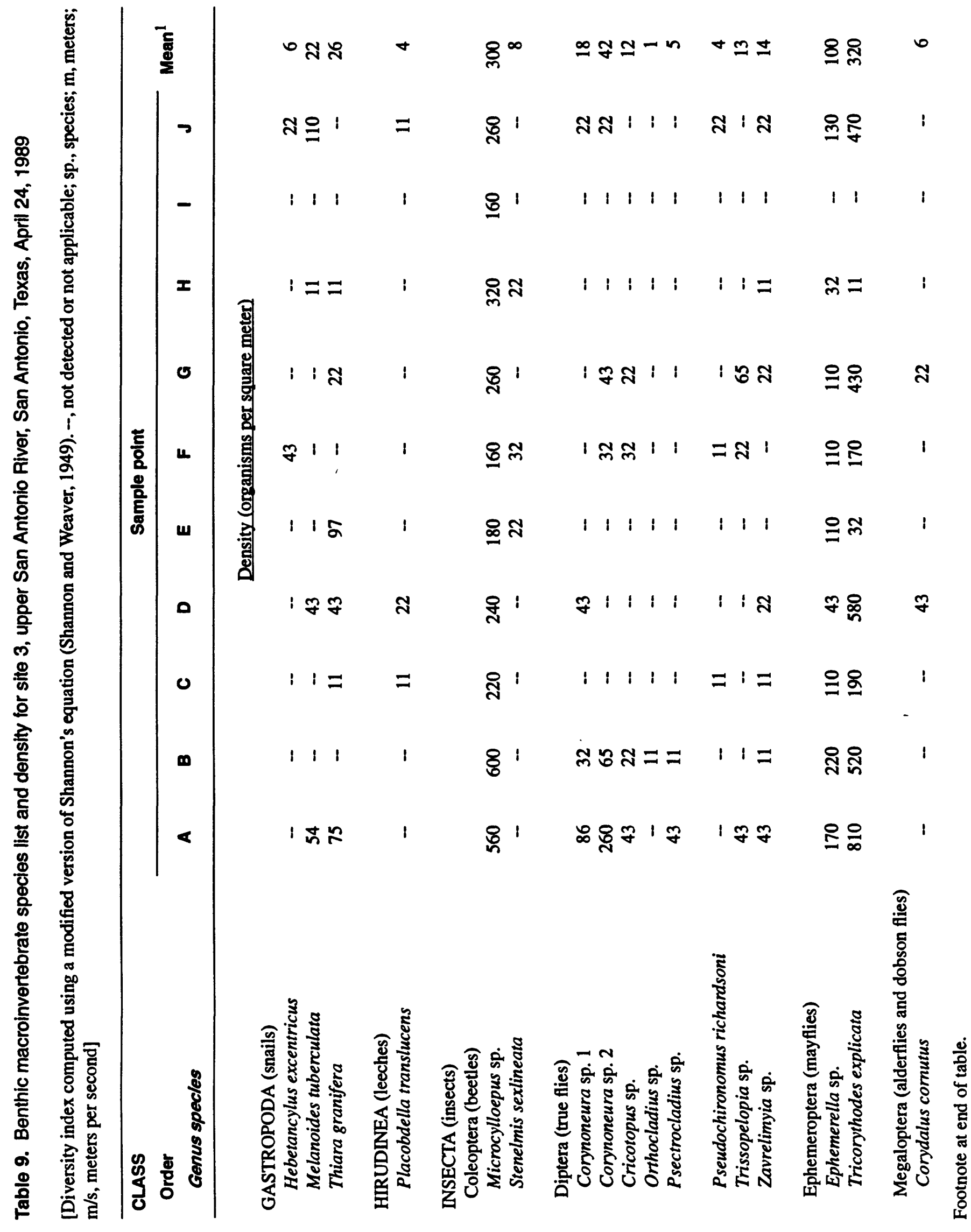




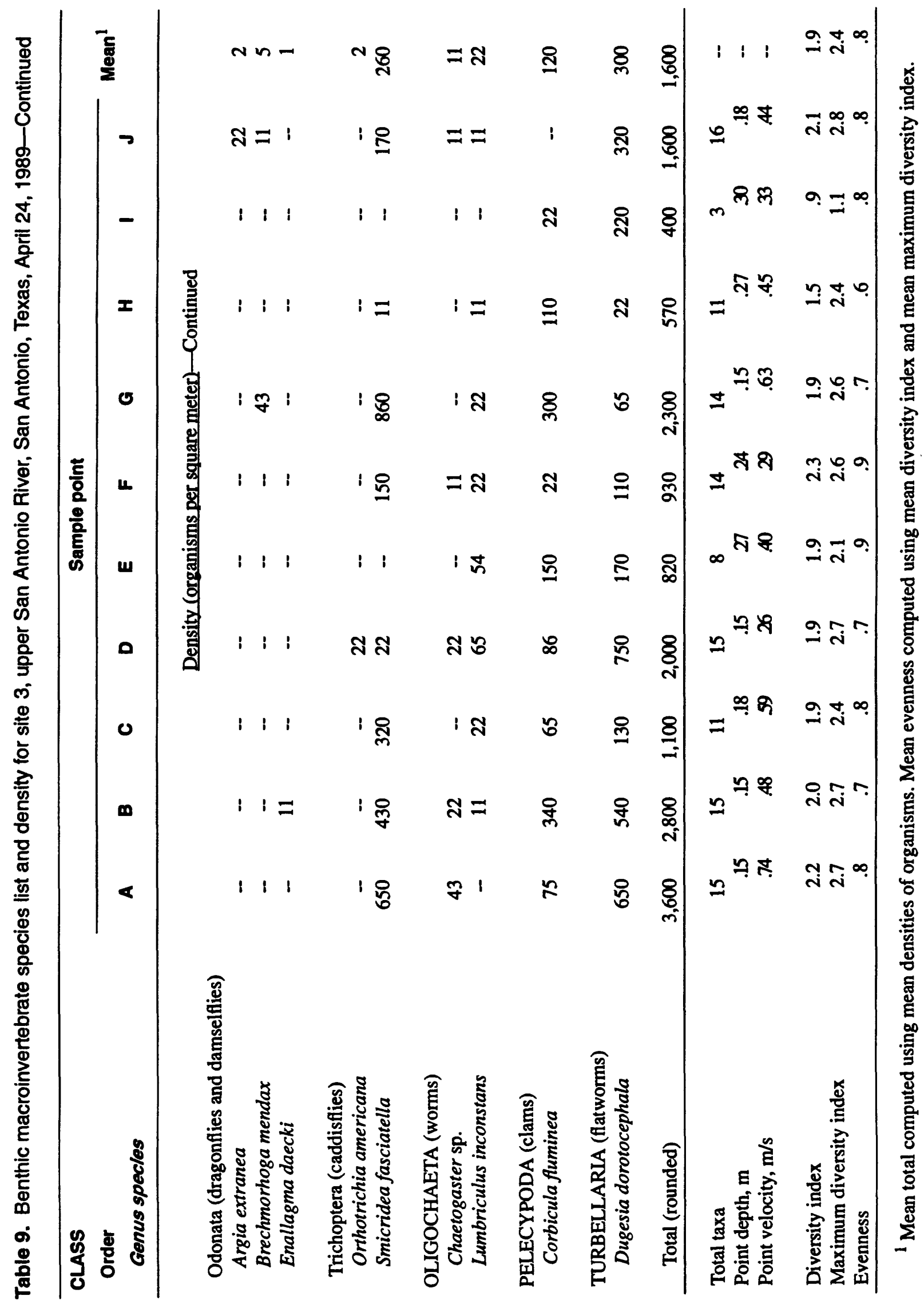

42 Blological and Associated Water-Quality Data for Lower Olmos Creek and Upper San Antonlo River, San Antonio, Texas, April-September 1989 


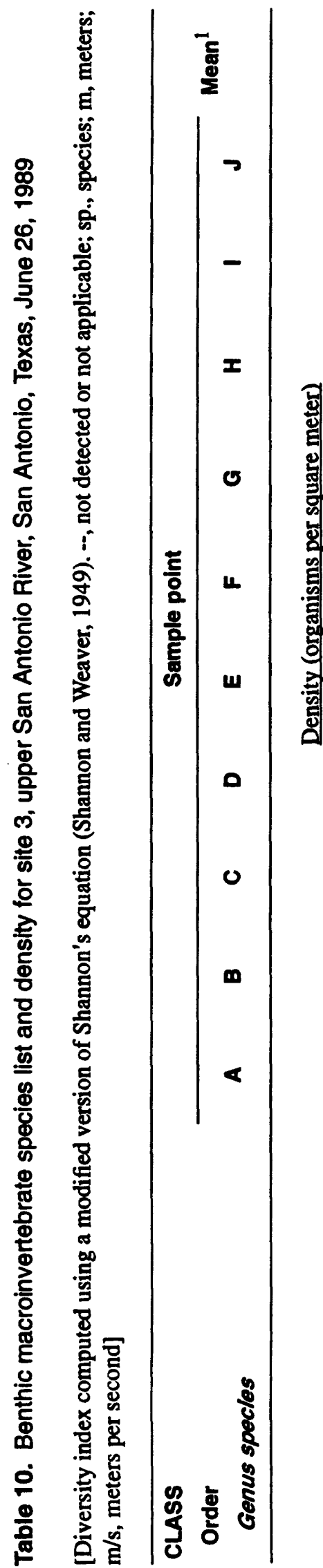

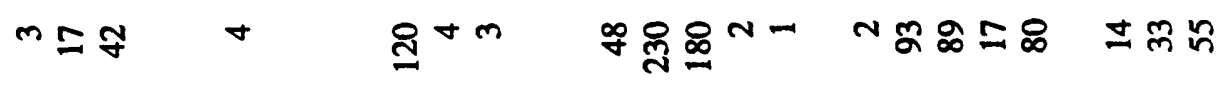

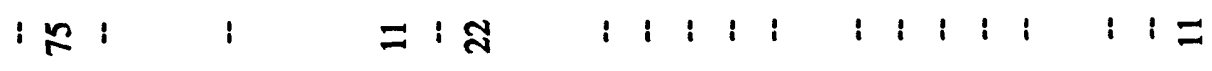

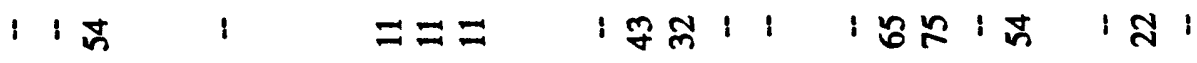

$$
\begin{aligned}
& =:=\quad \text { 8: } \\
& \text { : : } 1 \text { ก: } \\
& \text { I: }
\end{aligned}
$$

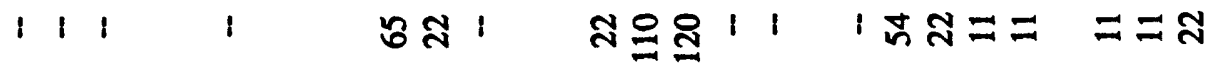

$$
\begin{aligned}
& 1: 1=1 \text { मี } \\
& \text { :ๆๆ } \\
& \text { : } \\
& \text { ส'! }
\end{aligned}
$$
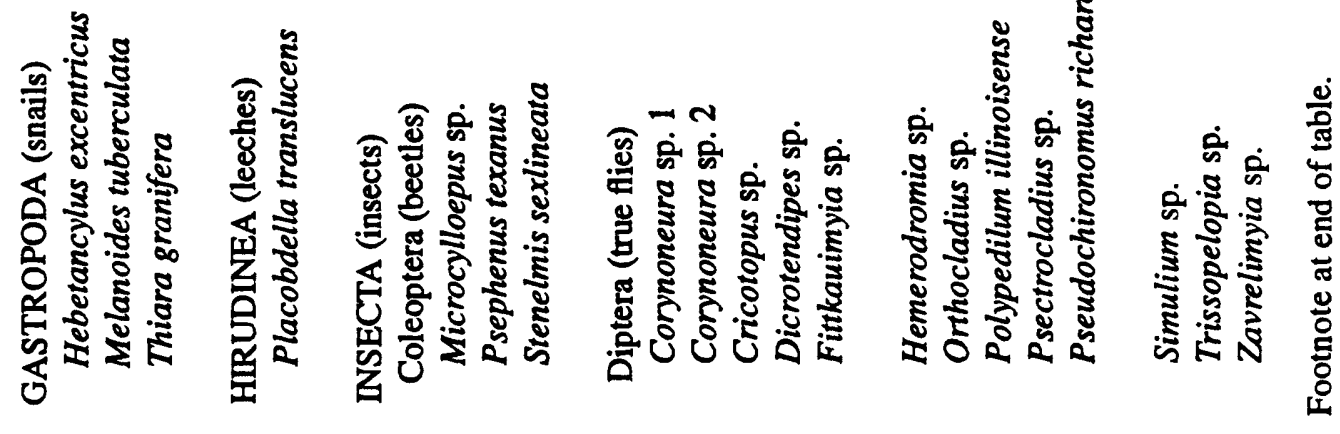


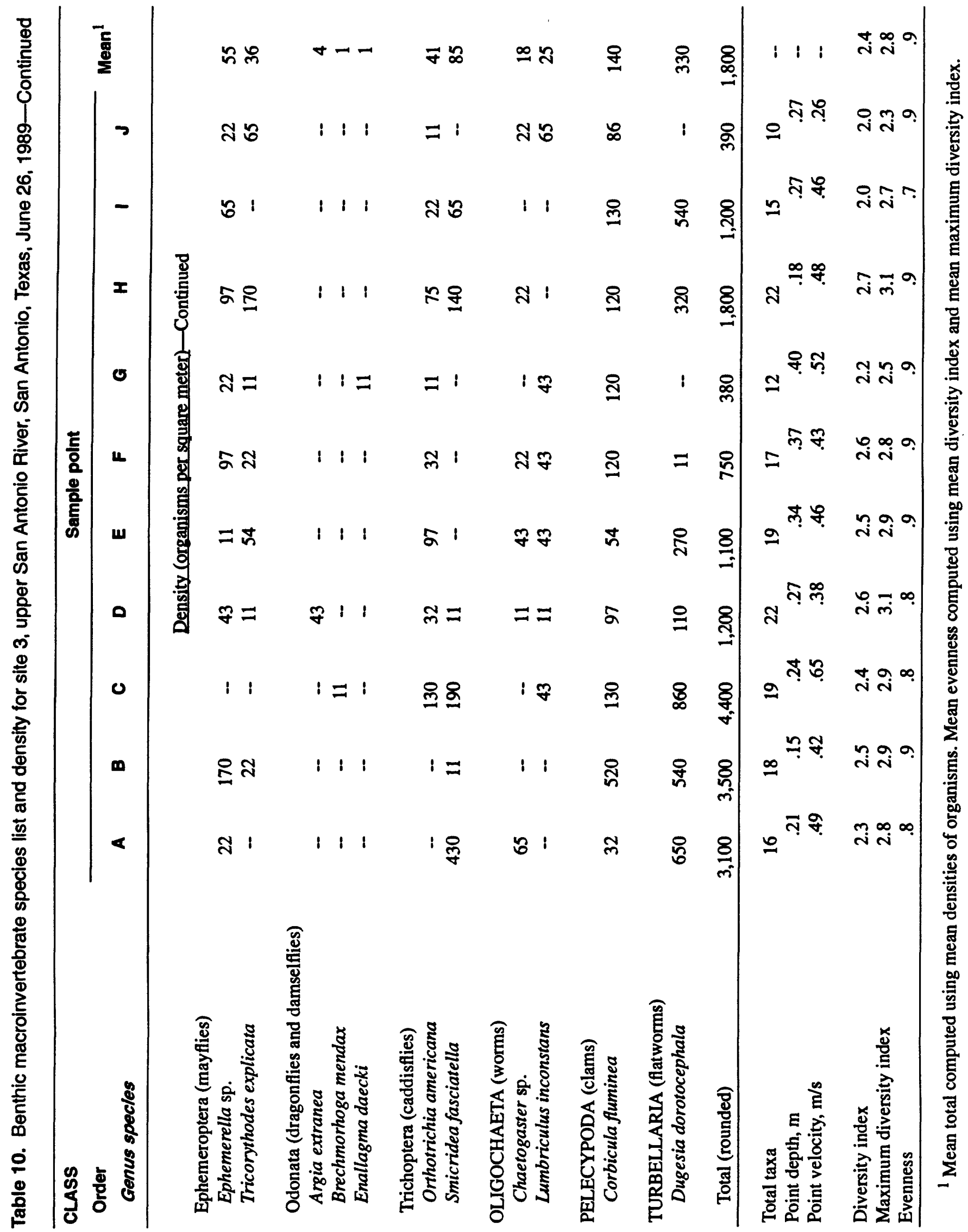

Blologlcal and Assoclated Water-Quality Data for Lower Olmos Croek and Upper San Antonlo Rlver, San Antonlo, Texas, Aprll-September 1989 


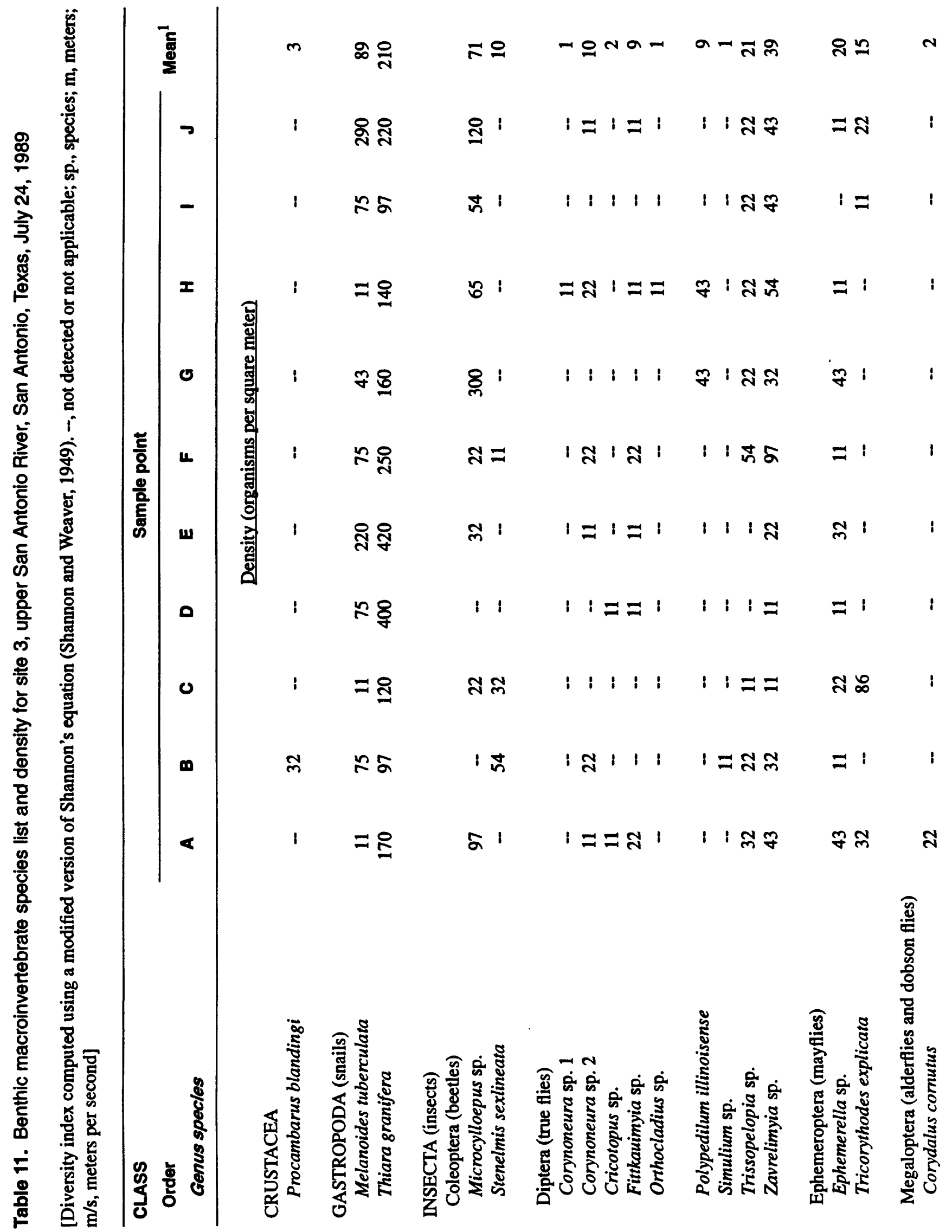

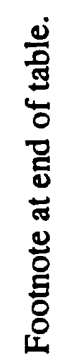




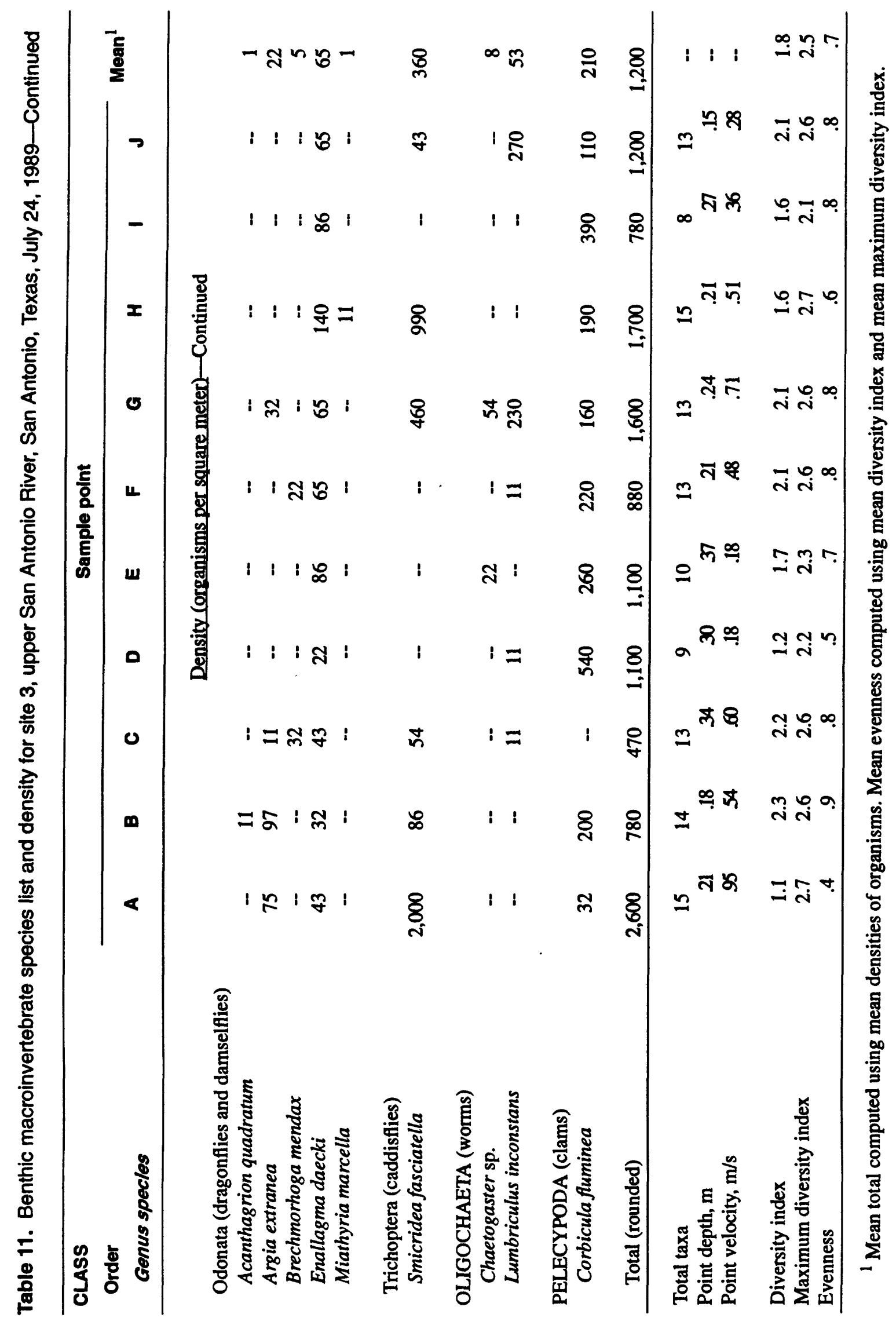

46 Biologlcal and Associated Water-Quality Data for Lower Olmos Creek and Upper San Antonlo River, San Antonio, Texas, April-September 1989 


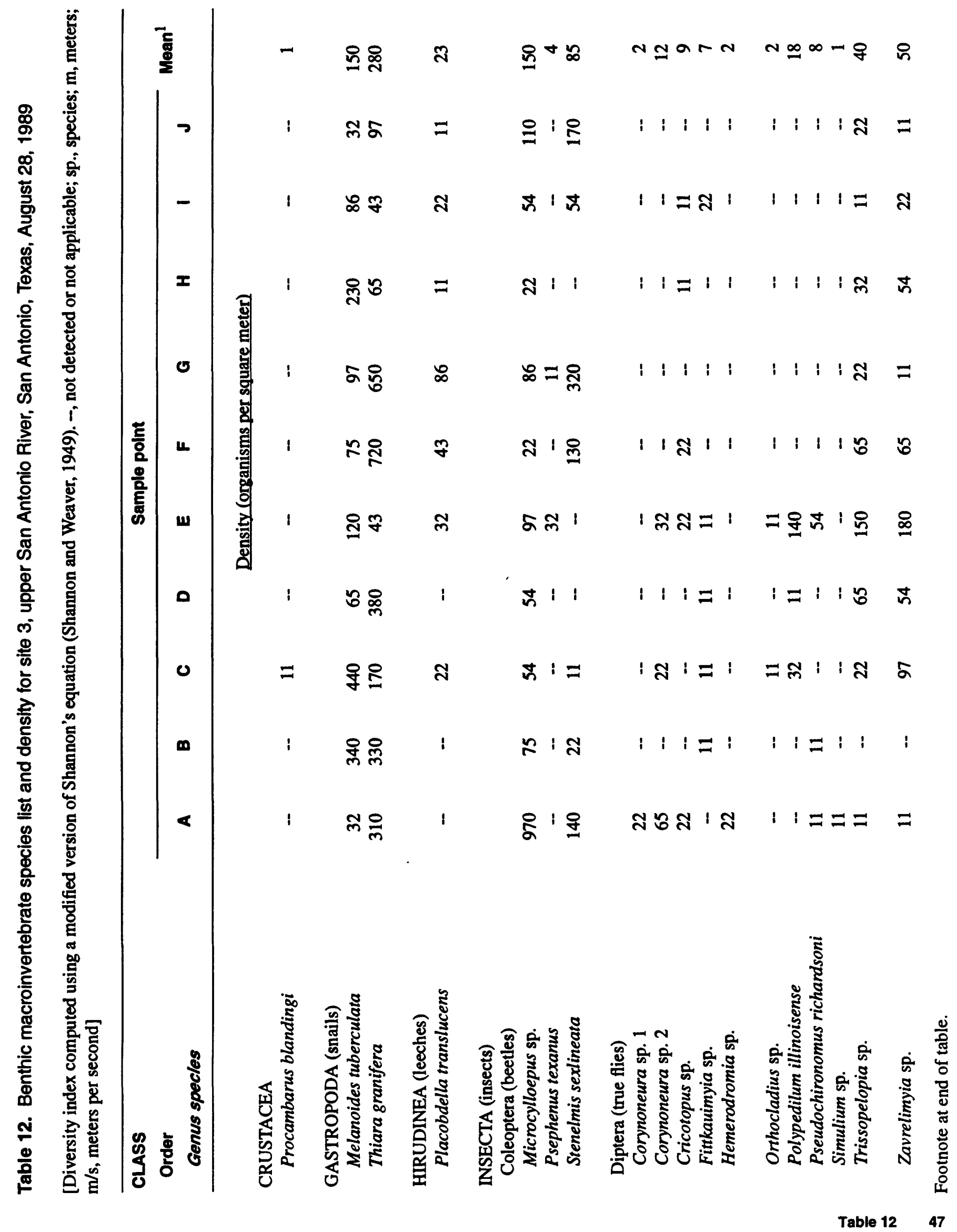




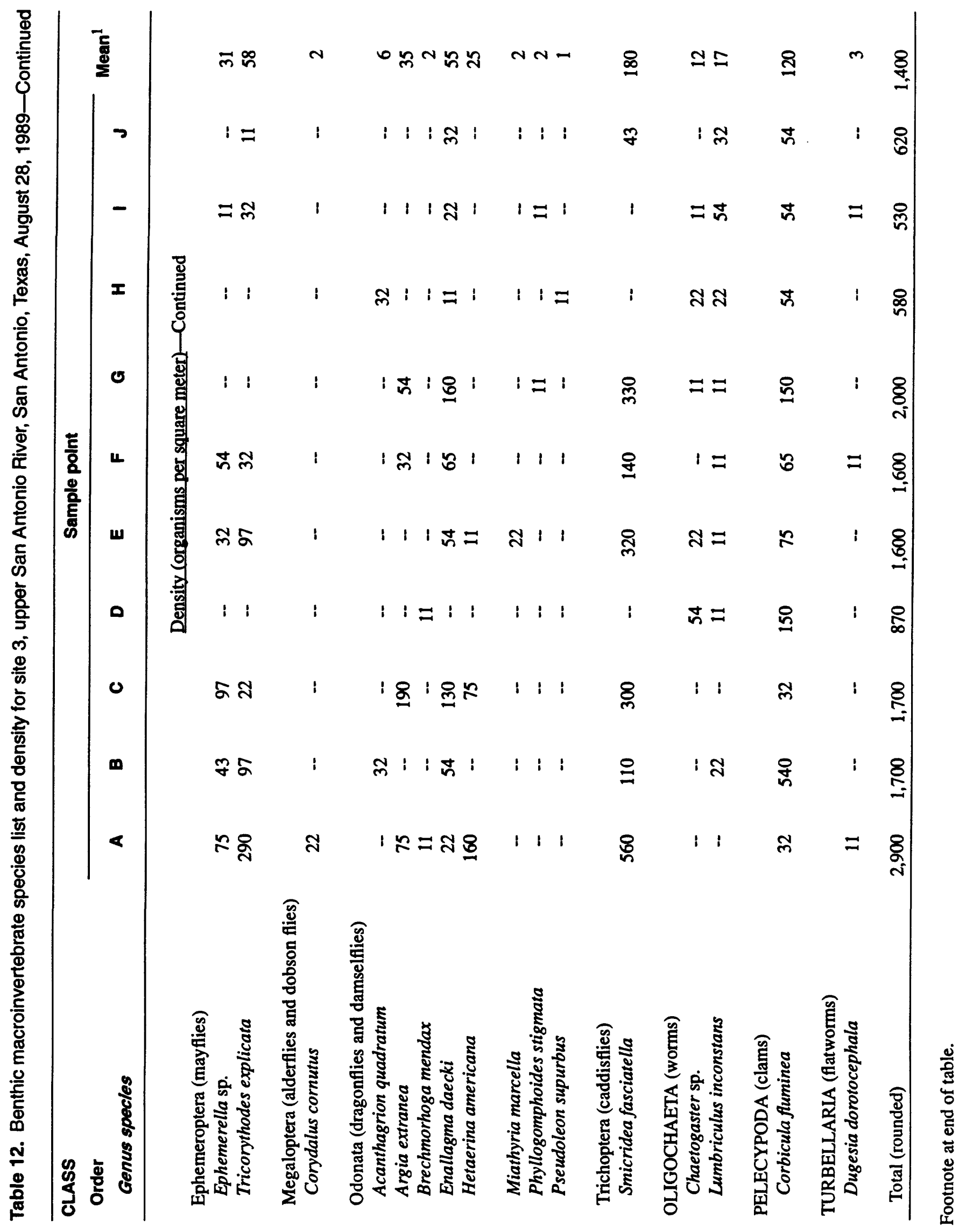

Biological and Associated Water-Quality Data for Lower Olmos Creek and Upper San Antonio River, San Antonio, Texas, April-September 1989 


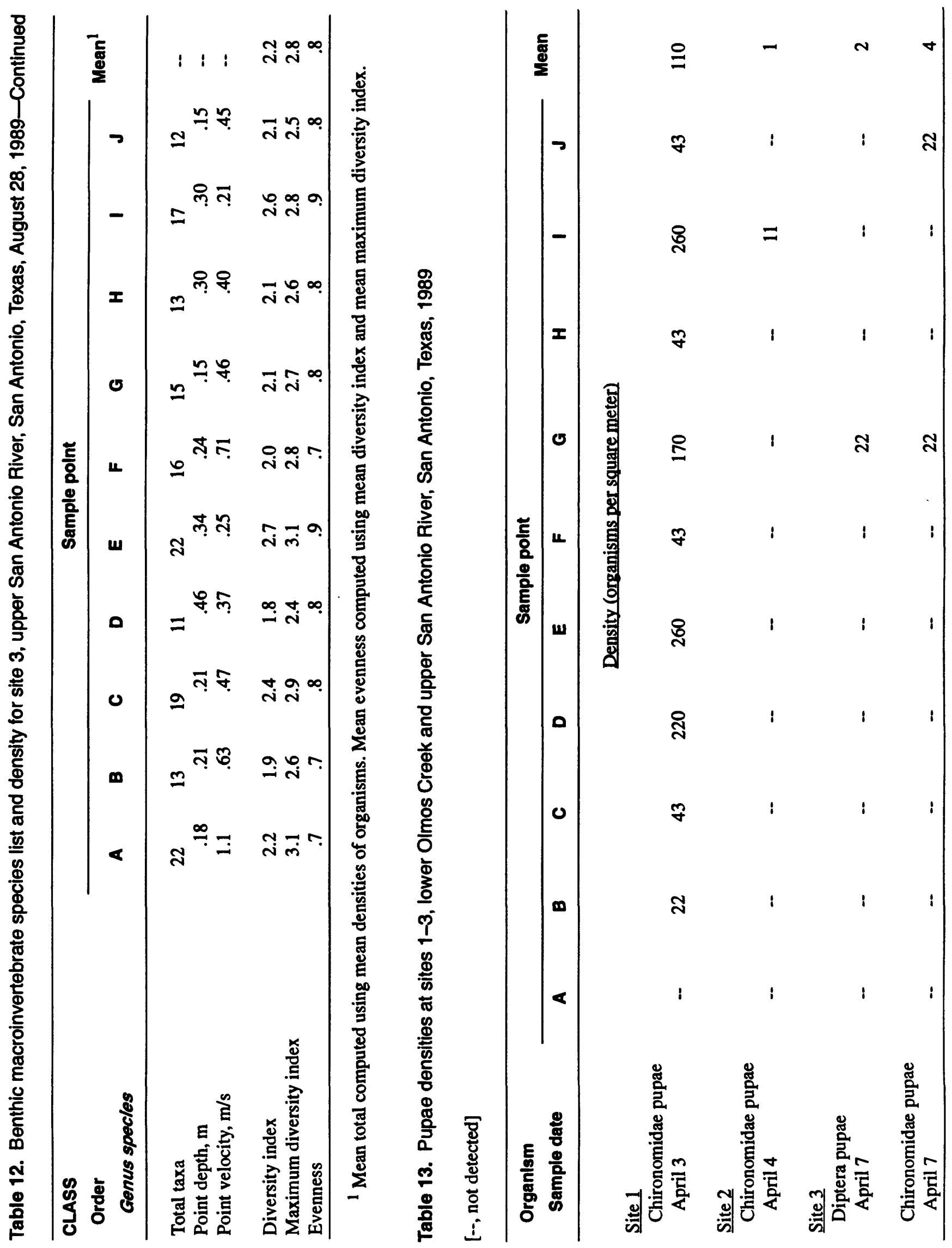


Table 14. Periphyton species list and density for site 1, lower Olmos Creek, San Antonio, Texas, 1989

[Diversity index computed using a modified version of Shannon's equation (Shannon and Weaver, 1949). --, not detected; ND, no data collected because of no-flow conditions; sp., species]

\begin{tabular}{|c|c|c|c|c|c|}
\hline \multirow{2}{*}{$\begin{array}{l}\text { DIVISION } \\
\text { Genus spocles }\end{array}$} & \multicolumn{5}{|c|}{ Sample date } \\
\hline & April 3 & April 26 & June 28 & July 26 & August 30 \\
\hline & \multicolumn{5}{|c|}{ Density (cells per square millimeter) } \\
\hline \multicolumn{6}{|l|}{ BACILLARIOPHYTA (diatoms) } \\
\hline Achnanthes lanceolata & - & 14 & ND & ND & ND \\
\hline Achnanthes minutissima & 200 & 300 & ND & ND & ND \\
\hline Amphora ovalis & - & 29 & ND & ND & ND \\
\hline Cocconeis placentula & 29 & - & ND & ND & ND \\
\hline Cyclotella sp. & - & 320 & ND & ND & ND \\
\hline Cymatopleura solea & 7 & - & ND & ND & ND \\
\hline Cymbella minuta & 14 & 85 & ND & ND & ND \\
\hline Cymbella sp. & - & 14 & ND & ND & ND \\
\hline Fragilaria sp. & 7 & - & ND & ND & ND \\
\hline Gomphonema brasiliense & - & 14 & ND & ND & ND \\
\hline Gomphonema parvulum & 64 & 43 & ND & ND & ND \\
\hline Gomphonema sp. & 7 & - & ND & ND & ND \\
\hline Gomphonema subclavatum & 7 & - & ND & ND & ND \\
\hline Navicula accomoda & - & 29 & ND & ND & ND \\
\hline Navicula capitata & - & 14 & ND & ND & ND \\
\hline Navicula cryptocephala & 36 & 14 & ND & ND & ND \\
\hline Navicula cuspidata & 7 & 14 & ND & ND & ND \\
\hline Navicula lateropunctata & - & 14 & ND & ND & ND \\
\hline Navicula orbiculata & 36 & - & ND & ND & ND \\
\hline Navicula pupula & 7 & - & ND & ND & ND \\
\hline Navicula rhychocephala & -- & 29 & ND & ND & ND \\
\hline Navicula rhyncocephala & 7 & - & ND & ND & ND \\
\hline Navicula sp. & 21 & 71 & ND & ND & ND \\
\hline Navicula texana & - & 14 & ND & ND & ND \\
\hline Navicula tripunctata & 7 & 85 & ND & ND & ND \\
\hline Nitzschia acicularis & 14 & 14 & ND & ND & ND \\
\hline Nitzschia amphibia & 71 & -- & ND & ND & ND \\
\hline Nitzschia dissipata & 110 & 230 & ND & ND & ND \\
\hline Nitzschia filiformis & 29 & - & ND & ND & ND \\
\hline Nitzschia frustulum & 150 & 130 & ND & ND & ND \\
\hline Nitzschia hungarica & - & 130 & ND & ND & ND \\
\hline Nitzschia linearis & - & 14 & ND & ND & ND \\
\hline Nitzschia microcephala & - & 85 & ND & ND & ND \\
\hline Nitzschia palea & 93 & 300 & ND & ND & ND \\
\hline Nitzschia sp. & 36 & - & ND & ND & ND \\
\hline Rhoicosphenia curvata & 29 & 43 & ND & ND & ND \\
\hline Stephanodiscus sp. & 52 & - & ND & ND & ND \\
\hline Surirella ovata & - & 14 & ND & ND & ND \\
\hline Synedra ulna & 7 & 14 & ND & ND & ND \\
\hline
\end{tabular}


Table 14. Periphyton species list and density for site 1, lower Olmos Creek, San Antonio, Texas, 1989-Continued

\begin{tabular}{|c|c|c|c|c|c|}
\hline \multirow{2}{*}{$\begin{array}{l}\text { DIVISION } \\
\text { Cenus specles }\end{array}$} & \multicolumn{5}{|c|}{ Sample date } \\
\hline & April 3 & April 26 & June 28 & July 26 & August 30 \\
\hline & \multicolumn{5}{|c|}{ Density (cells per square millimeter) - Continued } \\
\hline \multicolumn{6}{|c|}{ CHLOROPHYTA (green algae) } \\
\hline Actinastrum hantzschii & 52 & - & ND & ND & ND \\
\hline Chlorococcum sp. & 17 & - & ND & ND & ND \\
\hline Unknown chlorococcum & - & 41 & ND & ND & ND \\
\hline \multicolumn{6}{|c|}{ CYANOPHYTA (blue-green algae) } \\
\hline Gongrosira sp. & - & 82 & ND & ND & ND \\
\hline Lyngbya sp. & 44 & - & ND & ND & ND \\
\hline Lyngbya subtilis & - & 350 & ND & ND & ND \\
\hline Oscillatoria & 1,700 & 3,000 & ND & ND & ND \\
\hline Spirulina sp. & - & 41 & ND & ND & ND \\
\hline \multicolumn{6}{|c|}{ XANTHOPHYTA (yellow-green algae) } \\
\hline Vaucheria sp. & - & 21 & ND & ND & ND \\
\hline Total (rounded) & 2,900 & 5,600 & ND & ND & ND \\
\hline Total taxa & 29 & 33 & ND & ND & ND \\
\hline Diversity index & 1.8 & 2.0 & ND & ND & ND \\
\hline Maximum diversity index & 3.4 & 3.5 & ND & ND & ND \\
\hline Evenness & .5 & .6 & ND & ND & ND \\
\hline
\end{tabular}


Table 15. Periphyton species list and density for site 2, upper San Antonio River, San Antonio, Texas, 1989

[Diversity index computed using a modified version of Shannon's equation (Shannon and Weaver, 1949). --, not detected; sp., species]

\begin{tabular}{lccccc}
\hline DIVISION & \multicolumn{5}{c}{ Sample date } \\
\cline { 2 - 6 } Genus specles & April 4 & April 25 & June 27 & July 25 & August 29 \\
\hline
\end{tabular}

BACILLARIOPHYTA (diatoms)

Achnanthes exigua

Achnanthes microcephala

Achnanthes minutissima

Amphipleura pellucida

Amphora ovalis

Bacillaria paradoxa

Caloneis lewisii

Caloneis ventricosa

Cocconeis diminuta

Cocconeis placentula

Cyclotella sp.

Cymatopleura elliptica

Cymbella affinis

Cymbella cymbiformis

Cymbella sp.

Diploneis sp.

Fragilaria leptostauron

Fragilaria sp.

Gomphonema angustatum

Gomphonema constrictum

Gomphonema olivaceum

Gomphonema parvulum

Gomphonema sp.

Gyrosigma obtusatum

Melosira sp.

Meridion circulare

Navicula amphibia

Navicula capitata

Navicula cryptocephala

Navicula lateropunctata

Navicula minuscula

Navicula orbiculata

Navicula radiosa

Navicula rhynchocephala

Navicula sp.

Navicula texana

Navicula tripunctata

Nitzschia acicularis

Nitzschia amphibia

Nitzschia dissipata
Density (cells per square millimeter)

$\begin{array}{rrrrr}- & 36 & - & - & - \\ 120 & - & - & - & - \\ 1,400 & 640 & - & - & - \\ -- & - & - & 100 & - \\ 120 & - & - & - & -\end{array}$

$-$

120

230

$-$

$-\quad 210$

- 43

-

- $\quad 71$

470

120

350

120

230

$-$

-
$-\quad 460$

230

230

$-$

300

650

-

1,100

$-$

$-$

$-$

10

43

$-$

180

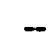

$-$

$-$

$-$

$-$

$-$

6,500

11,000

$-$

$-$

$-$

$-$

$-$

36

$-$

36

86

- $\quad-$

$\begin{array}{ll}- & 140\end{array}$

$\begin{array}{ll}- & 36\end{array}$

-
$-\quad 110$

$\begin{array}{ll}- & 36\end{array}$

120

140

-
$-\quad 36$

-- -

350

470

120

230

120

940

1,200
$-$

140

140

36

$-$ 
Table 15. Periphyton species list and density for site 2, upper San Antonio River, San Antonio, Texas, 1989-Continued

\begin{tabular}{|c|c|c|c|c|c|}
\hline \multirow{2}{*}{$\begin{array}{l}\text { DIVISION } \\
\text { Genus specles }\end{array}$} & \multicolumn{5}{|c|}{ Sample date } \\
\hline & April 4 & April 25 & June 27 & July 25 & August 29 \\
\hline & \multicolumn{5}{|c|}{ Density (cells per square millimeter)-Continued } \\
\hline Nitzschia filiformis & 700 & - & - & - & - \\
\hline Nitzschia flexa & - & 36 & - & - & - \\
\hline Nitzschia frustulum & 120 & 360 & - & - & - \\
\hline Nitzschia microcephala & 350 & - & - & - & - \\
\hline Nitzschia palea & 820 & 360 & - & - & - \\
\hline Nitzschia paradoxa & 350 & - & - & - & - \\
\hline Nitzschia sp. & 820 & 180 & - & - & - \\
\hline Pinnularia biceps & - & - & - & - & 9,000 \\
\hline Pinnularia flexuosa & 120 & - & - & - & - \\
\hline Stephanodiscus sp. & - & 43 & - & - & - \\
\hline Surirella biseriata & - & - & -- & - & 1,100 \\
\hline Surirella patella & - & 36 & - & 100 & 1,100 \\
\hline Synedra fasicula & - & 36 & 650 & 510 & - \\
\hline Synedra ulna & - & - & 2,000 & 100 & 1,100 \\
\hline \multicolumn{6}{|l|}{ CHLOROPHYTA (green algae) } \\
\hline Chlorella & - & - & 6,500 & 1,400 & 4,500 \\
\hline Chlorococcum sp. & 74 & - & - & - & - \\
\hline Cladophora glomerata & - & 260 & - & - & - \\
\hline Cylindrocapsa geminella & 590 & - & - & - & - \\
\hline Rhizoclonium sp. & 740 & - & - & - & - \\
\hline Tetraedron minimum & - & 43 & - & - & - \\
\hline Unknown chlorococcoid & - & 87 & - & - & - \\
\hline \multicolumn{6}{|l|}{ CYANOPHYTA (blue-green algae) } \\
\hline Anabaena & - & - & 4,600 & 100 & 3,400 \\
\hline Lyngbya aeruginea-caerulea & - & 910 & - & - & - \\
\hline Lyngbya digueti & 1,700 & - & - & - & - \\
\hline Microcystis aeruginosa & - & - & 29,000 & 6,300 & 44,000 \\
\hline Oscillatoria & 7,000 & 2,400 & - & 100 & 3,400 \\
\hline Phormidium sp. & 590 & - & - & - & - \\
\hline Spirulina sp. & - & 170 & - & - & - \\
\hline \multicolumn{6}{|l|}{ EUGLENOPHYTA (euglenoids) } \\
\hline Trachelomonas & -- & - & 2,000 & 200 & 7,800 \\
\hline Total (rounded) & 22,000 & 7,800 & 66,000 & 10,000 & 110,000 \\
\hline Total taxa & 34 & 33 & 11 & 11 & 17 \\
\hline Diversity index & 2.8 & 2.7 & 1.8 & 1.4 & 2.2 \\
\hline Maximum diversity index & 3.5 & 3.5 & 2.4 & 2.4 & 2.8 \\
\hline Evenness & 8 & .8 & .8 & .6 & .8 \\
\hline
\end{tabular}


Table 16. Periphyton species list and density for site 3, upper San Antonio River, San Antonio, Texas, 1989

[Diversity index computed using a modified version of Shannon's equation (Shannon and Weaver, 1949). --, not detected; sp., species]

\begin{tabular}{|c|c|c|c|c|c|}
\hline \multirow{2}{*}{$\begin{array}{l}\text { DIVISION } \\
\text { Genus spocles }\end{array}$} & \multicolumn{5}{|c|}{ Sample date } \\
\hline & April 7 & Aprll 24 & June 26 & July 24 & August \\
\hline & \multicolumn{5}{|c|}{ Density (cells per square millimeter) } \\
\hline \multicolumn{6}{|l|}{ BACILLARIOPHYTA (diatoms) } \\
\hline Achnanthes microcephala & - & 19 & - & - & - \\
\hline Achnanthes minutissima & 570 & 600 & - & - & - \\
\hline Achnanthes sp. & - & 57 & - & - & - \\
\hline Amphipleura pellucida & - & 19 & - & - & - \\
\hline Bacillaria paradoxa & - & - & - & 660 & - \\
\hline Biddulphia laevis & - & - & 1,000 & - & - \\
\hline Cocconeis diminuta & - & - & 5,700 & 6,600 & 4,500 \\
\hline Cocconeis pediculus & 30 & - & - & - & - \\
\hline Cocconeis placentula & 600 & 620 & - & - & - \\
\hline Cymbella affinis & - & 19 & - & - & - \\
\hline Cymbella gracilis & - & - & - & 660 & - \\
\hline Cymbella minuta & 15 & - & - & - & - \\
\hline Cymbella sp. & 15 & - & - & - & - \\
\hline Epithema sp. & - & 19 & - & - & - \\
\hline Fragilaria construens & 15 & - & - & - & - \\
\hline Fragilaria sp. & 90 & 130 & - & - & - \\
\hline Gomphonema brasiliense & - & 38 & - & - & - \\
\hline Gomphonema constrictum & -- & - & 2,600 & 2,600 & 690 \\
\hline Gomphonema olivaceum & 230 & 150 & - & - & - \\
\hline Gomphonema parvulum & 90 & 300 & - & - & - \\
\hline Gomphonema subclavatum & 15 & 19 & - & $\overline{-}$ & -- \\
\hline Gyrosigma obtusatum & 30 & - & 2,600 & 3,300 & 1,000 \\
\hline Melosira sp. & 180 & 440 & - & - & - \\
\hline Meridion circulare & - & - & 1,500 & 2,000 & 4,200 \\
\hline Navicula capitata & 60 & - & - & - & - \\
\hline Navicula cryptocephala & 30 & 76 & - & - & - \\
\hline Navicula decussis & - & 38 & - & - & -- \\
\hline Navicula lateropunctata & 60 & 76 & -- & -- & -- \\
\hline Navicula minuscula & 120 & 38 & - & - & - \\
\hline Navicula orbiculata & 120 & 76 & - & - & - \\
\hline Navicula radiosa & - & - & 520 & 1,300 & 690 \\
\hline Navicula rhynchocephala & 75 & 170 & - & - & -- \\
\hline Navicula sp. & 110 & 94 & - & - & - \\
\hline Navicula tripunctata & - & 38 & - & - & - \\
\hline Nitzschia acicularis & - & 19 & - & - & - \\
\hline Nitzschia dissipata & 150 & 360 & - & - & -- \\
\hline Nitzschia fonticola & 15 & - & - & - & -- \\
\hline Nitzschia frustulum & 75 & 76 & - & - & -- \\
\hline
\end{tabular}


Table 16. Periphyton species list and density for site 3, upper San Antonio River, San Antonio, Texas, 1989-Continued

\begin{tabular}{|c|c|c|c|c|c|}
\hline \multirow{2}{*}{$\begin{array}{l}\text { DIVISION } \\
\text { Cenus specles }\end{array}$} & \multicolumn{5}{|c|}{ Sample date } \\
\hline & April 7 & April 24 & June 26 & July 24 & August 28 \\
\hline & \multicolumn{5}{|c|}{ Density (cells per square millimeter)-Continued } \\
\hline Nitzschia linearis & 60 & 38 & -- & -- & -- \\
\hline Nitzschia microcephala & - & 19 & - & - & -- \\
\hline Nitzschia palea & 90 & 150 & - & - & - \\
\hline Nitzschia sp. & 30 & 38 & - & - & - \\
\hline Pinnularia biceps & - & - & 520 & 2,000 & 690 \\
\hline Rhoicosphenia curvata & - & 38 & - & -- & - \\
\hline Surirella angustata & - & - & - & 2,000 & - \\
\hline Surirella ovata & - & 38 & - & - & - \\
\hline Surirella patella & - & - & - & - & 1,000 \\
\hline Surirella tenera & - & - & - & -- & 350 \\
\hline Synedra ulna & - & 76 & 1,000 & 2,600 & - \\
\hline \multicolumn{6}{|c|}{ CHLOROPHYTA (green algae) } \\
\hline Chaetophora elegans & - & 1,800 & - & - & - \\
\hline Chlamydomonas & - & - & 2,100 & 3,300 & 3,800 \\
\hline Chlorella & - & - & 4,100 & 4,600 & 3,800 \\
\hline Rhizoclonium & - & - & - & 1,300 & - \\
\hline Unknown chlorococcoid & 23 & - & - & - & - \\
\hline \multicolumn{6}{|c|}{ CYANOPHYTA (blue-green algae) } \\
\hline Anabaena & 45 & 560 & 3,600 & 4,000 & 2,800 \\
\hline Microcystis aeruginosa & - & - & 20,000 & 22,000 & 10,000 \\
\hline Oscillatoria & 1,300 & 3,800 & 6,200 & 6,600 & 350 \\
\hline Synechococcus sp. & 68 & - & - & - & - \\
\hline \multicolumn{6}{|c|}{ EUGLENOPHYTA (euglenoids) } \\
\hline Trachelomonas & - & - & - & - & 350 \\
\hline Total (rounded) & 4,300 & 10,000 & 51,000 & 66,000 & 34,000 \\
\hline Total taxa & 29 & 34 & 13 & 16 & 14 \\
\hline Diversity index & 2.5 & 2.3 & 2.0 & 2.3 & 2.2 \\
\hline Maximum diversity index & 3.4 & 3.5 & 2.6 & 2.8 & 2.6 \\
\hline Evenness & .7 & .7 & .8 & .8 & .8 \\
\hline
\end{tabular}


Table 17. Phytoplankton species list and density for site 1, lower Olmos Creek, San Antonio, Texas, 1989

[Diversity index computed using a modified version of Shannon's equation (Shannon and Weaver, 1949). ND, no data collected because of no-flow conditions; sp., species]

\begin{tabular}{|c|c|c|c|}
\hline \multirow{2}{*}{$\begin{array}{l}\text { DIVISION } \\
\text { Genus specles }\end{array}$} & \multicolumn{3}{|c|}{ Sample date } \\
\hline & April 3 & June 28 & August 30 \\
\hline & \multicolumn{3}{|c|}{ Density (cells per milliliter) } \\
\hline \multicolumn{4}{|c|}{ BACILLARIOPHYTA (diatoms) } \\
\hline Achnanthes deflexa & 60 & ND & ND \\
\hline Achnanthes minutissima & 220 & ND & ND \\
\hline Cocconeis placentula & 20 & ND & ND \\
\hline Cyclotella ocellata & 620 & ND & ND \\
\hline Gomphonema sp. & 60 & ND & ND \\
\hline Navicula cryptocephala & 20 & ND & ND \\
\hline Navicula cuspidata & 20 & ND & ND \\
\hline Navicula jaernefeltii & 40 & ND & ND \\
\hline Navicula minima & 40 & ND & ND \\
\hline Navicula radiosa & 40 & ND & ND \\
\hline Navicula texana & 40 & ND & ND \\
\hline Navicula sp. & 60 & ND & ND \\
\hline Nitzschia amphibia & 20 & ND & ND \\
\hline Nitzschia angustata & 40 & ND & ND \\
\hline Nitzschia dissipata & 60 & ND & ND \\
\hline Nitzschia hungarica & 80 & ND & ND \\
\hline Nitzschia linearis & 20 & ND & ND \\
\hline Nitzschia microcephala & 20 & ND & ND \\
\hline Nitzschia palea & 120 & ND & ND \\
\hline Nitzschia sp. & 100 & ND & ND \\
\hline Stephanodiscus sp. & 310 & ND & ND \\
\hline Synedra ulna & 40 & ND & ND \\
\hline \multicolumn{4}{|l|}{ CHLOROPHYTA (green algae) } \\
\hline Ankistrodesmus falcatus & 190 & ND & ND \\
\hline Chlamydomonas sp. & 2,400 & ND & ND \\
\hline Chodatella quadriseta & 940 & ND & ND \\
\hline Elakatothrix viridis & 380 & ND & ND \\
\hline Franceia droescheri & 2,100 & ND & ND \\
\hline Gloeocystis ampla & 4,100 & ND & ND \\
\hline Kirchneriella subsolitaria & 380 & ND & ND \\
\hline Nannochloris sp. & 190 & ND & ND \\
\hline Oocystis sp. & 750 & ND & ND \\
\hline Tetraedron trigonum & 190 & ND & ND \\
\hline Tetraspora lacustris & 190 & ND & ND \\
\hline Treubaria setigerum & 190 & ND & ND \\
\hline Unknown coccoid & 2,100 & ND & ND \\
\hline
\end{tabular}


Table 17. Phytoplankton species list and density for site 1, lower Olmos Creek, San Antonio, Texas, 1989-Continued

\begin{tabular}{lccc}
\hline DIVISION & & Sample date & \\
Genus spocles & April 3 & June 28 & August 30 \\
\cline { 2 - 4 } & & Density (cells per milliliter)-Continued \\
CHRYSOPHYTA (golden-brown algae) & & & ND \\
Kephyrion sp. & 190 & ND & \\
CRYPTOPHYTA (cryptophytes) & & & ND \\
Cryptomonas erosa & 190 & ND & ND \\
Rhodomonas minuta & 380 & ND & \\
CYANOPHYTA (blue-green algae) & & & ND \\
Aphanocapsa delicatissima & 2,400 & ND & ND \\
Chroococcus dispersus & 7,100 & ND & ND \\
Chroococcus limneticus & 1,100 & ND & ND \\
Chroococcus minutus & 4,900 & ND & ND \\
Dactylococcopsis fascicularis & 1,500 & ND & ND \\
Gloeothece linearis & 190 & ND & ND \\
Oscillatoria & 940 & ND & ND \\
Total (rounded) & 35,000 & ND & ND \\
\hline Total taxa & 45 & ND & ND \\
Diversity index & 2.8 & ND & ND \\
Maximum diversity index & 3.8 & & ND \\
Evenness & .7 & & \\
\hline
\end{tabular}


Table 18. Phytoplankton species list and density for site 2, upper San Antonio River, San Antonio, Texas, 1989

[Diversity index computed using a modified version of Shannon's equation (Shannon and Weaver, 1949). --, not detected; sp., species]

\begin{tabular}{|c|c|c|c|}
\hline \multirow{2}{*}{$\begin{array}{l}\text { DIVISION } \\
\text { Genus specles }\end{array}$} & \multicolumn{3}{|c|}{ Sample date } \\
\hline & April 4 & June 27 & August 29 \\
\hline & \multicolumn{3}{|c|}{ Density (cells per milliliter) } \\
\hline \multicolumn{4}{|c|}{ BACILLARIOPHYTA (diatoms) } \\
\hline Achnanthes minutissima & 82 & - & - \\
\hline Achnanthes sp. & 21 & - & - \\
\hline Asterionella formosa & 21 & - & - \\
\hline Cocconeis placentula & 41 & - & - \\
\hline Cyclotella ocellata & 110 & - & - \\
\hline Cyclotella stelligera & - & - & 300 \\
\hline Cymbella affinis & 21 & 190 & - \\
\hline Cymbella turgidula & 120 & - & - \\
\hline Navicula cryptocephala & 42 & - & - \\
\hline Navicula hambergii & 41 & - & - \\
\hline Navicula minima & 21 & - & - \\
\hline Navicula pupula & - & 380 & - \\
\hline Navicula radiosa & - & 570 & 2,700 \\
\hline Navicula sp. & 61 & - & - \\
\hline Navicula tripunctata & 82 & - & - \\
\hline Nitzschia acicularis & 21 & - & - \\
\hline Nitzschia filiformis & 21 & - & - \\
\hline Nitzschia fonticola & 21 & - & - \\
\hline Nitzschia palea & 270 & - & - \\
\hline Pinnularia biceps & - & 1,100 & 600 \\
\hline Surirella ovata & 21 & - & - \\
\hline Surirella patella & - & 190 & -- \\
\hline Surirella robusta & - & - & 900 \\
\hline Synedra ulna & - & 950 & 1,800 \\
\hline \multicolumn{4}{|l|}{ CHLOROPHYTA (green algae) } \\
\hline Chlamydomonas sp. & 560 & - & 1,200 \\
\hline Chlorella sp. & - & 2,300 & 2,700 \\
\hline Closterium sp. & - & 380 & - \\
\hline Cosmarium denticulatum & - & - & 900 \\
\hline Cosmarium ovale & - & 190 & - \\
\hline Oocystis pusilla & 450 & - & -- \\
\hline Tetraedron gracile & - & - & 600 \\
\hline Tetraedron muticum & 110 & - & - \\
\hline Unknown coccoid & 340 & - & - \\
\hline \multicolumn{4}{|c|}{ CRYPTOPHYTA (cryptophytes) } \\
\hline Cryptomonas erosa & 110 & - & - \\
\hline
\end{tabular}


Table 18. Phytoplankton species list and density for site 2, upper San Antonio River, San Antonio, Texas, 1989-Continued

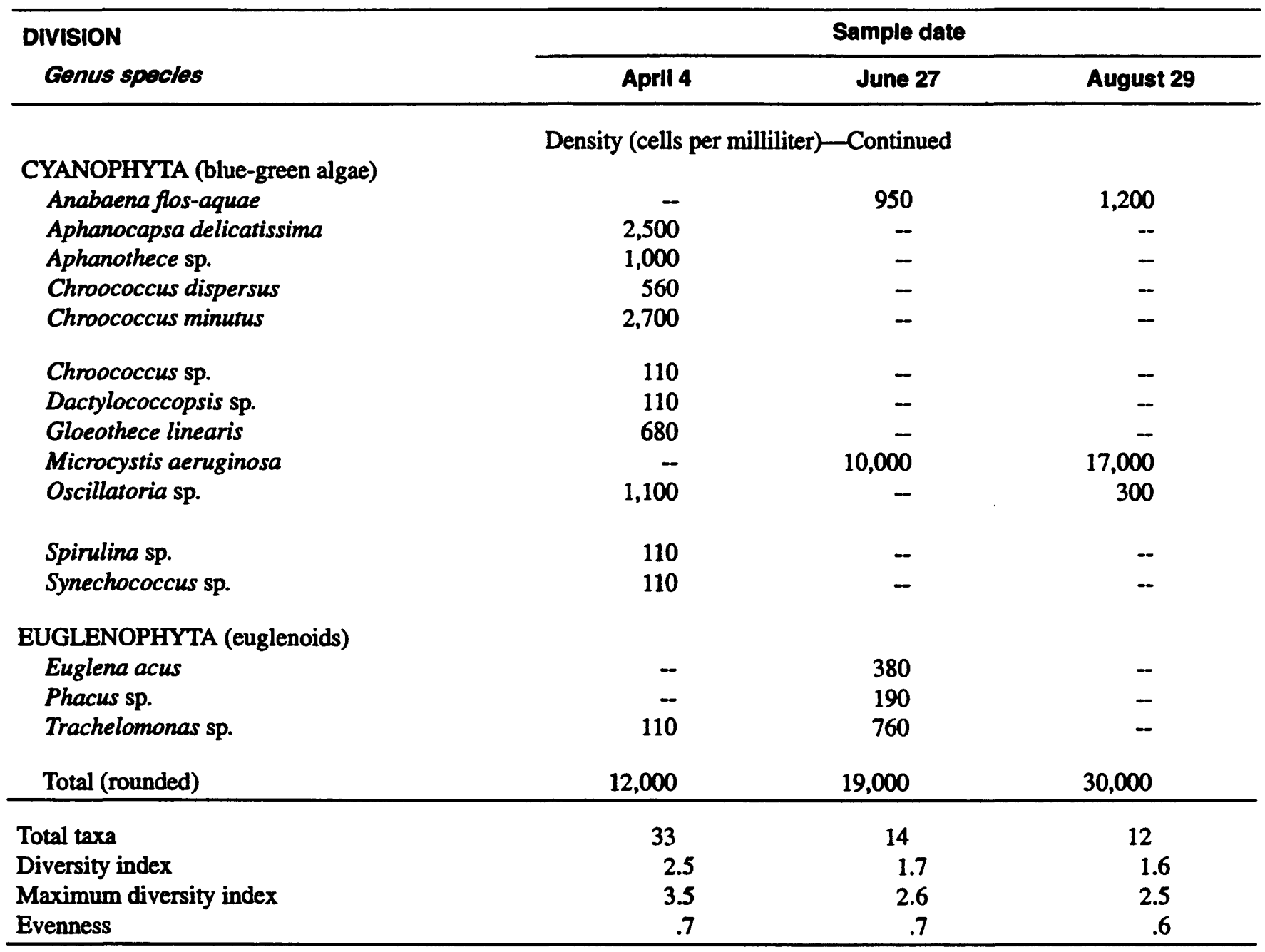


Table 19. Phytoplankton species list and density for site 3, upper San Antonio River, San Antonio, Texas, 1989

[Diversity index computed using a modified version of Shannon's equation (Shannon and Weaver, 1949). -, not detected; sp., species]

\begin{tabular}{|c|c|c|c|}
\hline \multirow{2}{*}{$\begin{array}{l}\text { DIVISION } \\
\text { Genus spocles }\end{array}$} & \multicolumn{3}{|c|}{ Sample date } \\
\hline & April 7 & June 26 & August \\
\hline & \multicolumn{3}{|c|}{ Density (cells per milliliter) } \\
\hline \multicolumn{4}{|l|}{ BACILLARIOPHYTA (diatoms) } \\
\hline Bacillaria paradoxa & - & - & 940 \\
\hline Cocconeis diminuta & -- & 1,200 & 940 \\
\hline Cocconeis placentula & 19 & - & - \\
\hline Cyclotella stelligera & - & - & 1,400 \\
\hline Cymatopleura solea & 9 & 400 & - \\
\hline Gomphonema constrictum & - & 1,600 & - \\
\hline Gomphonema subclavatum & 9 & - & - \\
\hline Melosira ambigua & - & - & 470 \\
\hline Meridion circulare & - & 400 & - \\
\hline Navicula grimmei & 9 & - & - \\
\hline Navicula radiosa & - & 800 & 1,400 \\
\hline Navicula sp. & 19 & - & - \\
\hline Nitzschia dissipata & 28 & - & - \\
\hline Nitzschia fonticola & - & - & 940 \\
\hline Nitzschia palea & 19 & 400 & - \\
\hline Pinnularia biceps & - & - & 2,800 \\
\hline Pinnularia latevittata & - & - & 470 \\
\hline Surirella angustata & - & 800 & - \\
\hline Surirella robusta & - & 400 & - \\
\hline Synedra ulna & - & 800 & - \\
\hline \multicolumn{4}{|l|}{ CHLOROPHYTA (green algae) } \\
\hline Chlamydomonas sp. & 220 & - & - \\
\hline Chlorella sp. & - & 1,600 & 3,300 \\
\hline Franceia ovalis & 56 & - & - \\
\hline Unknown coccoid & 110 & - & - \\
\hline \multicolumn{4}{|l|}{ CRYPTOPHYTA (cryptophytes) } \\
\hline Cryptomonas sp. & 56 & - & - \\
\hline \multicolumn{4}{|c|}{ CYANOPHYTA (blue-green algae) } \\
\hline Anabaena flos-aquae & -- & 2,000 & 470 \\
\hline Aphanocapsa delicatissima & 1,400 & - & - \\
\hline Aphanothece sp. & 390 & - & -- \\
\hline Chroococcus minutus & 1,200 & - & - \\
\hline Chroococcus sp. & 680 & - & - \\
\hline Gloeothece linearis & 56 & - & - \\
\hline Lyngbya sp. & 280 & - & - \\
\hline Microcystis aeruginosa & - & 26,000 & 32,000 \\
\hline Oscillatoria sp. & 220 & - & - \\
\hline
\end{tabular}


Table 19. Phytoplankton species list and density for site 3, upper San Antonio River, San Antonio, Texas, 1989-Continued

\begin{tabular}{lccc}
\hline DIVISION & \multicolumn{3}{c}{ Sample date } \\
\cline { 2 - 4 } Genus specles & April 7 & June 26 & August 28 \\
\hline & Density (cells per milliliter) & Continued & \\
Synechococcus sp. & 170 & - & - \\
EUGLENOPHYTA (euglenoids) & & & \\
$\quad$ Euglena sp. & - & - & - \\
$\quad$ Euglena acus & - & 1,200 & 940 \\
Trachelomonas sp. & - & 2,000 & 47,000 \\
$\quad$ Total (rounded) & 5,000 & 40,000 & 13 \\
\hline Total taxa & 19 & 14 & 1.4 \\
Diversity index & 2.1 & 1.5 & 2.6 \\
Maximum diversity index & 2.9 & 2.6 & .5 \\
Evenness & .7 & .6 & \\
\hline
\end{tabular}

Table 20. Water-quality data for site 1, lower Olmos Creek, San Antonio, Texas, 1989

$\left[\mathrm{m}^{3} / \mathrm{s}\right.$, cubic meters per second; $\mu \mathrm{S} / \mathrm{cm}$, microsiemens per centimeter at $25^{\circ} \mathrm{C} ;{ }^{\circ} \mathrm{C}$, degrees Celsius; NTU, nephelometric turbidity unit; $\mathrm{mg} / \mathrm{L}$, milligrams per liter; $\mathrm{mm}$, millimeters; $\mathrm{Hg}$, mercury; $\mathrm{CaCO}_{3}$, calcium carbonate; - , not determined; $\mathrm{N}$, nitrogen; $\mathrm{NO}_{2}+\mathrm{NO}_{3}$, nitrite plus nitrate; $\mathrm{P}$, phosphorus; $\mu \mathrm{g} / \mathrm{L}$, micrograms per liter; $\mu \mathrm{g} / \mathrm{g}$ micrograms per gram; $<$, less than]

\begin{tabular}{|c|c|c|c|c|c|c|c|c|c|c|c|c|}
\hline Date & Time & $\begin{array}{l}\text { Dis- } \\
\text { charge, } \\
\text { instan- } \\
\text { taneous } \\
\left(\mathrm{m}^{3} / \mathrm{s}\right)\end{array}$ & $\begin{array}{c}\text { Specific } \\
\text { conduct- } \\
\text { ance } \\
(\mu S / \mathrm{cm})\end{array}$ & $\begin{array}{l}\text { PH } \\
\text { (stand- } \\
\text { ard } \\
\text { units) }\end{array}$ & $\begin{array}{l}\text { Temper- } \\
\text { ature } \\
\left({ }^{\circ} \mathrm{C}\right)\end{array}$ & $\begin{array}{l}\text { Color } \\
\text { (plat- } \\
\text { inum- } \\
\text { cobalt } \\
\text { units) }\end{array}$ & $\begin{array}{l}\text { Tur- } \\
\text { bidity } \\
\text { (NTU) }\end{array}$ & $\begin{array}{l}\text { Oxygen, } \\
\text { dis- } \\
\text { solved } \\
\text { (mgh) }\end{array}$ & $\begin{array}{c}\text { Baro- } \\
\text { metric } \\
\text { pressure } \\
\text { (mm of } \\
\mathrm{Hg} \text { ) }\end{array}$ & $\begin{array}{c}\text { Oxygen, } \\
\text { dissolved } \\
\text { (percent } \\
\text { satu- } \\
\text { ration) }\end{array}$ & $\begin{array}{l}\text { Oxygen } \\
\text { demand, } \\
\text { blochem- } \\
\text { ical, } 5 \text { day } \\
\text { (mg/) }\end{array}$ & $\begin{array}{l}\text { Hard- } \\
\text { ness, } \\
\text { total } \\
\left(\mathrm{mghl}^{2} \mathrm{as}\right. \\
\left.\mathrm{CaCO}_{3}\right)\end{array}$ \\
\hline \multicolumn{13}{|l|}{ Apr } \\
\hline $03 \ldots$ & 1310 & 0.01 & 404 & 7.7 & 26.0 & 30 & 12 & 7.1 & 741 & 90 & 4.2 & 160 \\
\hline $26 \ldots$ & 1120 & .01 & 545 & 7.4 & 23.0 & - & - & 3.2 & 747 & 38 & -- & -- \\
\hline
\end{tabular}

\begin{tabular}{|c|c|c|c|c|c|c|c|c|c|c|c|}
\hline Date & $\begin{array}{l}\text { Caicium, } \\
\text { dis- } \\
\text { solved } \\
\text { (mg/L) }\end{array}$ & $\begin{array}{l}\text { Magne- } \\
\text { sium, } \\
\text { dis- } \\
\text { solved } \\
\text { (mg/L) }\end{array}$ & $\begin{array}{l}\text { Sodium, } \\
\text { dis- } \\
\text { solved } \\
\text { (mg/L) }\end{array}$ & $\begin{array}{c}\text { Sodium } \\
\text { (percent) }\end{array}$ & $\begin{array}{l}\text { Sodium } \\
\text { adsorp- } \\
\text { tion } \\
\text { ratio }\end{array}$ & $\begin{array}{l}\text { Potas- } \\
\text { sium, } \\
\text { dis- } \\
\text { solved } \\
\text { (mg/l) }\end{array}$ & $\begin{array}{l}\text { Alka- } \\
\text { linity, } \\
\text { fleld } \\
\text { (mgl as } \\
\mathrm{CaCO}_{3} \text { ) }\end{array}$ & $\begin{array}{l}\text { Sulfate, } \\
\text { dis- } \\
\text { solved } \\
\text { (mghl) }\end{array}$ & $\begin{array}{l}\text { Chio- } \\
\text { ride, } \\
\text { dis- } \\
\text { solved } \\
\text { (mghl) }\end{array}$ & $\begin{array}{l}\text { Fluo- } \\
\text { ride, } \\
\text { dis- } \\
\text { solved } \\
\text { (mgll) }\end{array}$ & $\begin{array}{l}\text { Silica, } \\
\text { dls- } \\
\text { solved } \\
\text { (mgh) }\end{array}$ \\
\hline \multicolumn{12}{|l|}{ Apr } \\
\hline $03 \ldots$ & 56 & 6.0 & 16 & 17 & 0.5 & 5.6 & 130 & 44 & 15 & 0.30 & 7.9 \\
\hline $26 \ldots$ & - & - & -- & -- & - & -- & - & - & - & -- & -- \\
\hline
\end{tabular}


Table 20. Water-quality data for site 1, lower Olmos Creek, San Antonio, Texas, 1989-Continued

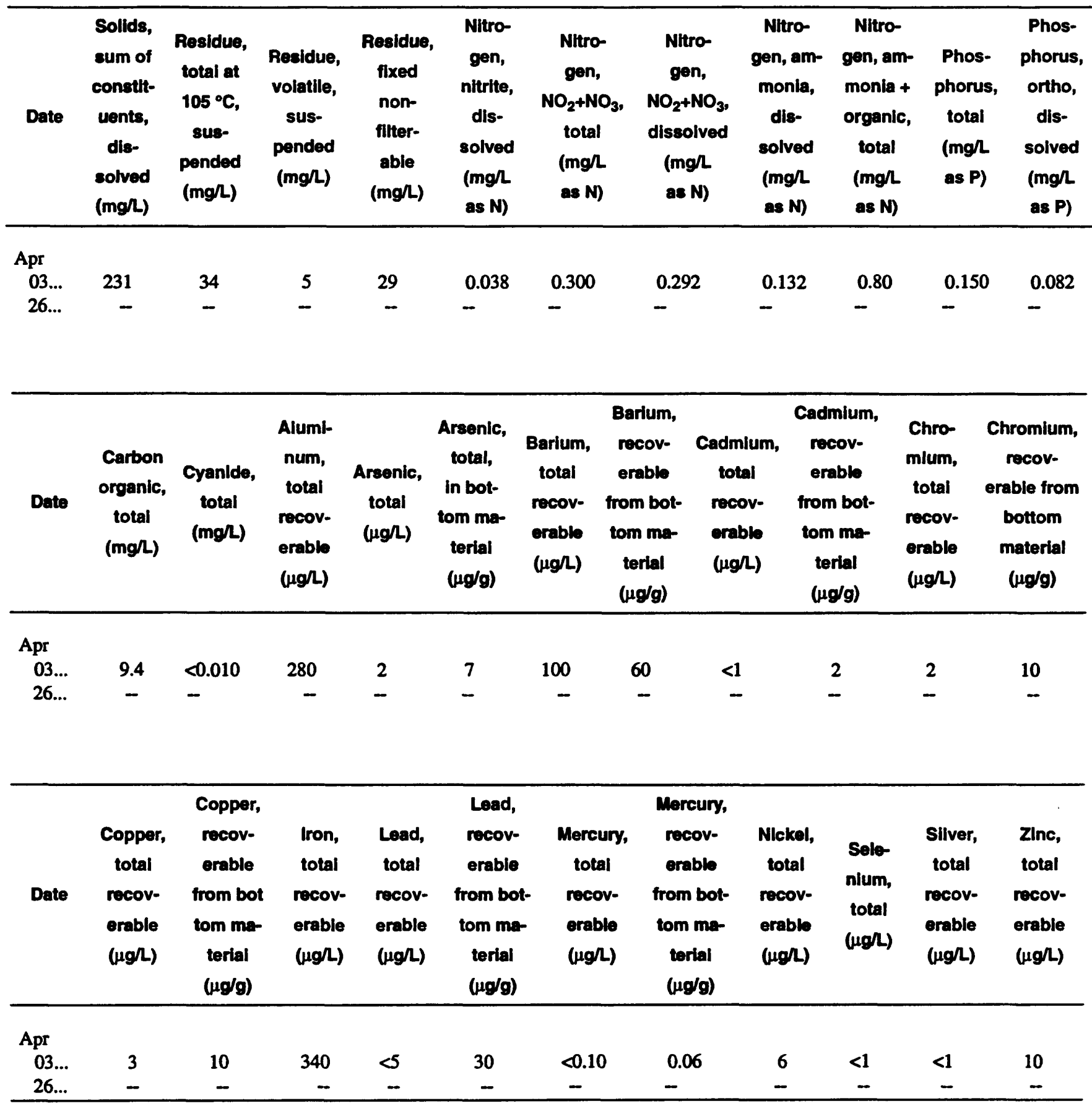


Table 21. Water-quality data for site 2, upper San Antonio River, San Antonio, Texas, 1989

$\left[\mathrm{m}^{3} / \mathrm{s}\right.$, cubic meters per second; $\mu \mathrm{S} / \mathrm{cm}$, microsiemens per centimeter at $25^{\circ} \mathrm{C} ;{ }^{\circ} \mathrm{C}$, degrees Celsius; NTU, nephelometric turbidity unit; $\mathrm{mg} / \mathrm{L}$, milligrams per liter; $\mathrm{mm}$, millimeters; $\mathrm{Hg}$, mercury; $\mathrm{CaCO}_{3}$, calcium carbonate; -, not determined; <, less than; $\mathrm{N}$, nitrogen; $\mathrm{NO}_{2}+\mathrm{NO}_{3}$, nitrite plus nitrate; $\mathrm{P}$, phosphorus; $\mu \mathrm{g} / \mathrm{L}$, micrograms per liter; $\mu \mathrm{g} / \mathrm{g}$ micrograms per gram]

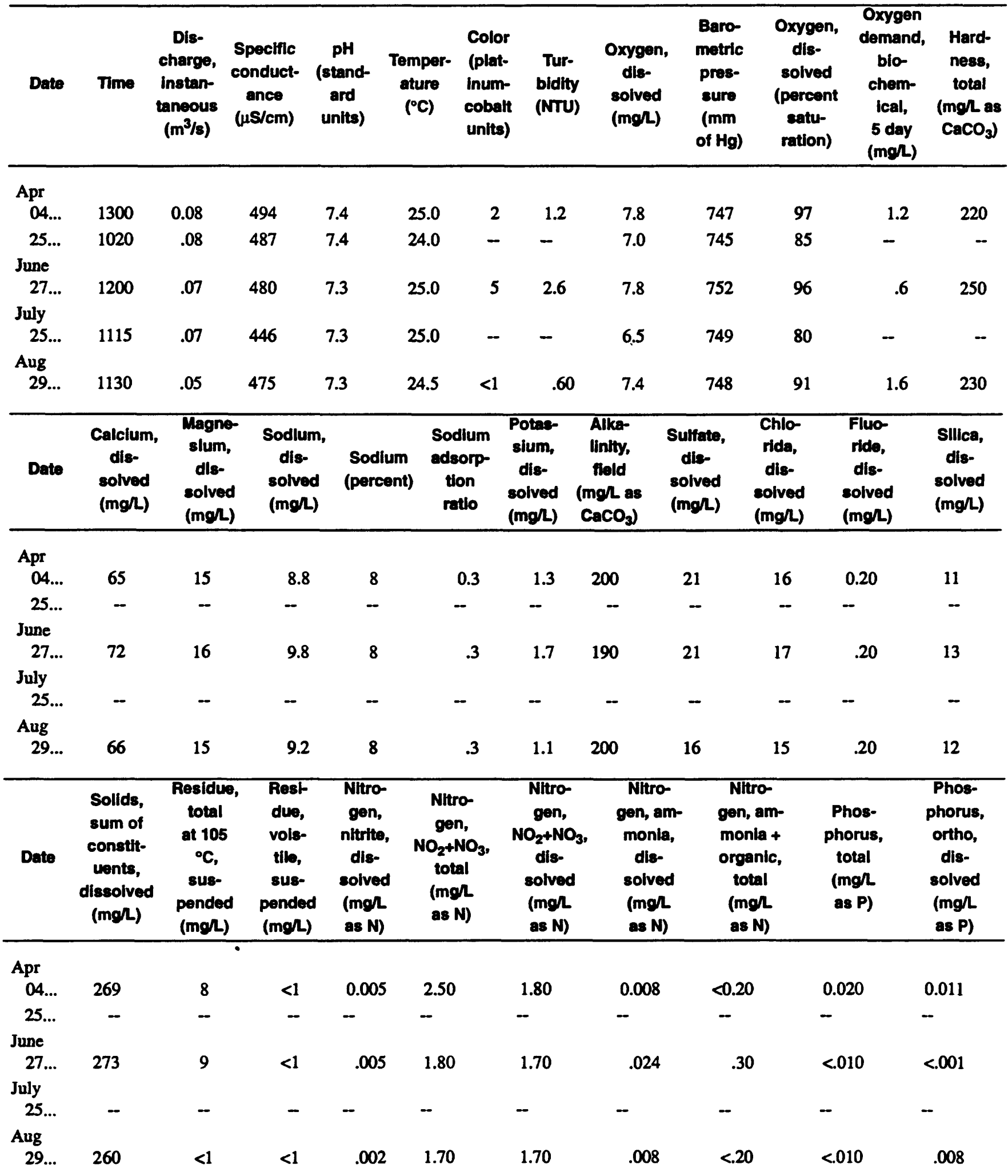


Table 21. Water-quality data for site 2, upper San Antonio River, San Antonio, Texas, 1989-Continued

\begin{tabular}{|c|c|c|c|c|c|c|c|c|c|c|c|}
\hline Date & $\begin{array}{c}\text { Carbon, } \\
\text { organic, } \\
\text { total } \\
\text { (mgl) }\end{array}$ & $\begin{array}{c}\text { Cyanide, } \\
\text { total } \\
\text { (mg/) }\end{array}$ & 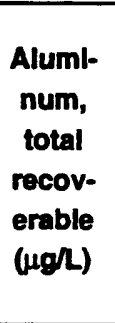 & $\begin{array}{c}\text { Arsenlc, } \\
\text { total } \\
(\mu g / L)\end{array}$ & $\begin{array}{l}\text { Arsenic, } \\
\text { total, } \\
\text { In bot- } \\
\text { tom ma- } \\
\text { terlal } \\
(\mu g / g)\end{array}$ & $\begin{array}{l}\text { Barium, } \\
\text { totai } \\
\text { recov- } \\
\text { erable } \\
(\mu g /)\end{array}$ & $\begin{array}{l}\text { Barium, } \\
\text { recov- } \\
\text { erable } \\
\text { from bot- } \\
\text { tom ma- } \\
\text { terial } \\
(\mu \mathrm{g} / \mathrm{g})\end{array}$ & 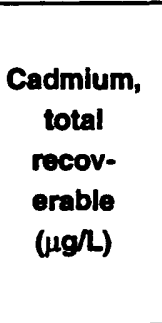 & $\begin{array}{c}\text { Cadmium, } \\
\text { recov- } \\
\text { erable } \\
\text { from bot- } \\
\text { tom ma- } \\
\text { terial } \\
(\mu g / g)\end{array}$ & $\begin{array}{l}\text { Chro- } \\
\text { mium, } \\
\text { total } \\
\text { recov- } \\
\text { erable } \\
(\mu g /)\end{array}$ & $\begin{array}{c}\text { Chro- } \\
\text { mlum, } \\
\text { rocov- } \\
\text { erable } \\
\text { from } \\
\text { bottom } \\
\text { materlal } \\
(\mu g / g)\end{array}$ \\
\hline \multicolumn{12}{|l|}{ Apr } \\
\hline $04 \ldots$ & 0.8 & $<0.010$ & 70 & $<1$ & 3 & 100 & 40 & 1 & 2 & 1 & 7 \\
\hline $25 \ldots$ & - & - & - & - & - & - & - & - & - & - & - \\
\hline \multicolumn{12}{|l|}{ June } \\
\hline $27 \ldots$ & .6 & $<.010$ & 150 & 1 & 3 & 100 & 20 & $<1$ & 3 & 2 & 8 \\
\hline \multicolumn{12}{|l|}{ July } \\
\hline $25 \ldots$ & - & - & - & -- & - & - & - & - & - & - & - \\
\hline \multicolumn{12}{|l|}{ Aug } \\
\hline $29 .$. & .6 & $<.010$ & 140 & $<1$ & 3 & $<100$ & $<100$ & $<1$ & 2 & 1 & 10 \\
\hline Date & $\begin{array}{l}\text { Copper, } \\
\text { total } \\
\text { recov- } \\
\text { erable } \\
(\mu g / L)\end{array}$ & $\begin{array}{l}\text { Copper, } \\
\text { rocov- } \\
\text { erable } \\
\text { trom bot- } \\
\text { tom ma- } \\
\text { terial } \\
(\mu g / g)\end{array}$ & $\begin{array}{l}\text { Iron, } \\
\text { total } \\
\text { recov- } \\
\text { erable } \\
(\mu g /)\end{array}$ & $\begin{array}{l}\text { Load, } \\
\text { total. } \\
\text { recov- } \\
\text { erable } \\
(\mu g /))\end{array}$ & $\begin{array}{l}\text { Lead, } \\
\text { rocov- } \\
\text { erable } \\
\text { from bot- } \\
\text { tom me- } \\
\text { terlal } \\
(\mu g / g)\end{array}$ & $\begin{array}{c}\text { Mercury, } \\
\text { total } \\
\text { recov- } \\
\text { erable } \\
(\mu g /) \text { ) }\end{array}$ & $\begin{array}{c}\text { Mercury, } \\
\text { recov- } \\
\text { erable } \\
\text { trom bot- } \\
\text { tom ma- } \\
\text { terlal } \\
(\mu \mathrm{g} / \mathrm{g}) \\
\end{array}$ & $\begin{array}{l}\text { Nickel, } \\
\text { total } \\
\text { recov- } \\
\text { erable } \\
(\mu g /)\end{array}$ & $\begin{array}{l}\text { Selo- } \\
\text { nium, } \\
\text { total } \\
(\mu g /)\end{array}$ & $\begin{array}{l}\text { Silver, } \\
\text { total } \\
\text { recov- } \\
\text { erable } \\
(\mu g /))\end{array}$ & $\begin{array}{l}\text { Zinc, } \\
\text { total } \\
\text { recov- } \\
\text { erable } \\
(\mu g / L)\end{array}$ \\
\hline \multicolumn{12}{|l|}{ Apr } \\
\hline $04 \ldots$ & 2 & 7 & 70 & $<5$ & 50 & $<0.10$ & 0.04 & 4 & $<1$ & $<1$ & 10 \\
\hline $25 \ldots$ & - & - & - & - & -- & - & - & - & - & - & - \\
\hline \multicolumn{12}{|l|}{ June } \\
\hline $27 \ldots$ & 2 & 7 & 120 & 2 & 40 & .10 & .03 & $<1$ & $<1$ & $<1$ & 10 \\
\hline \multicolumn{12}{|l|}{ July } \\
\hline $25 \ldots$ & - & - & - & - & - & - & - & - & - & - & - \\
\hline \multicolumn{11}{|l|}{ Aug } & $<10$ \\
\hline
\end{tabular}


Table 22. Water-quality data for site 3, upper San Antonio River, San Antonio, Texas, 1989

[m $\mathrm{m}^{3} / \mathrm{s}$, cubic meters per second; $\mu \mathrm{S} / \mathrm{cm}$, microsiemens per centimeter at $25^{\circ} \mathrm{C}$; ${ }^{\circ} \mathrm{C}$, degrees Celsius; NTU, nephelometric turbidity unit; mg/, milligrams per liter; mm, millimeters; $\mathrm{Hg}$, mercury; $\mathrm{CaCO}_{3}$, calcium carbonate; -, not determined; <, less than; $\mathrm{N}$, nitrogen;

$\mathrm{NO}_{2}+\mathrm{NO}_{3}$, nitrite plus nitrate; $\mathrm{P}$, phosphorus; $\mu \mathrm{g} / \mathrm{L}$, micrograms per liter; $\mu \mathrm{g} / \mathrm{g}$ micrograms per gram]

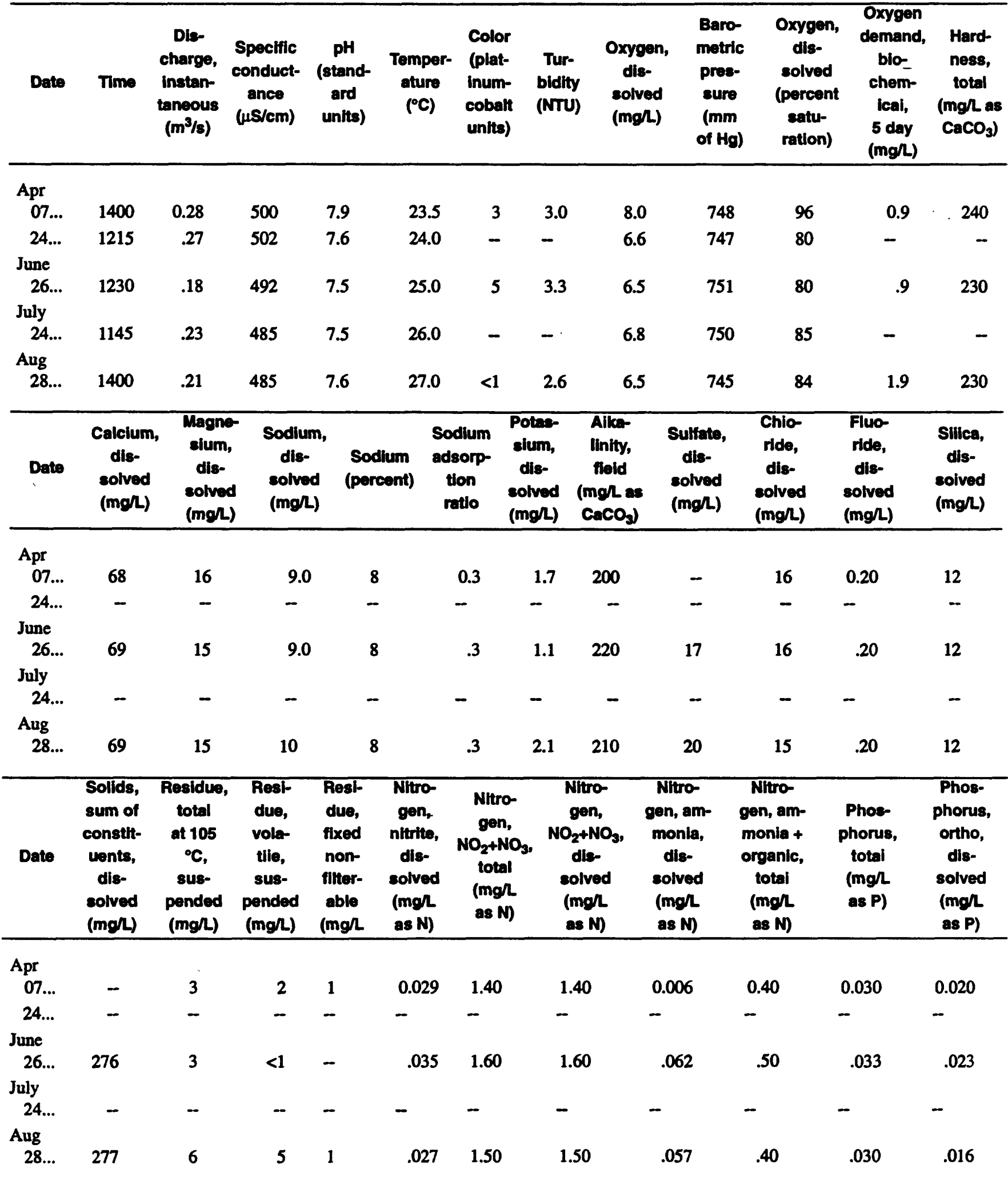


Table 22. Water-quality data for site 3, upper San Antonio River, San Antonio, Texas, 1989 -Continued

\begin{tabular}{|c|c|c|c|c|c|c|c|c|c|c|c|}
\hline Date & $\begin{array}{c}\text { Carbon, } \\
\text { organlc, } \\
\text { total } \\
\text { (mg/L) }\end{array}$ & $\begin{array}{c}\text { Cyanlde, } \\
\text { total } \\
\text { (mg/L) }\end{array}$ & $\begin{array}{l}\text { Alumt } \\
\text { num, } \\
\text { total } \\
\text { recov- } \\
\text { erable } \\
\text { ( } \mu g /) \text {. }\end{array}$ & $\begin{array}{c}\text { Arsenic, } \\
\text { total } \\
(\mu g / L)\end{array}$ & $\begin{array}{c}\text { Arsenic, } \\
\text { total, } \\
\text { In bot- } \\
\text { tom ma- } \\
\text { terlai } \\
(\mu g / g)\end{array}$ & $\begin{array}{l}\text { Barium, } \\
\text { total } \\
\text { recov- } \\
\text { erable } \\
(\mu g / L)\end{array}$ & $\begin{array}{l}\text { Barium, } \\
\text { recov- } \\
\text { orable } \\
\text { from bot- } \\
\text { tom ma- } \\
\text { terial } \\
(\mu g / g)\end{array}$ & 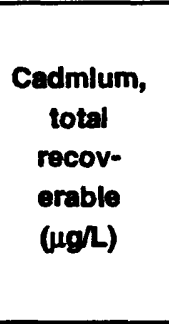 & $\begin{array}{c}\text { Cadmlum, } \\
\text { recov- } \\
\text { erable } \\
\text { from bot- } \\
\text { tom ma- } \\
\text { terial } \\
(\mu g / g)\end{array}$ & $\begin{array}{l}\text { Chro- } \\
\text { mlum, } \\
\text { total } \\
\text { recov- } \\
\text { erable } \\
(\mu g /))\end{array}$ & $\begin{array}{c}\text { Chro- } \\
\text { mlum, } \\
\text { recov- } \\
\text { erable } \\
\text { from } \\
\text { bottom } \\
\text { material } \\
(\mu g / g)\end{array}$ \\
\hline \multicolumn{12}{|l|}{ Apr } \\
\hline $07 \ldots$ & 1.1 & $<0.010$ & 100 & $<1$ & 3 & 100 & 80 & $<1$ & 2 & 2 & 10 \\
\hline $24 \ldots$ & - & - & - & - & - & - & - & - & - & - & - \\
\hline \multicolumn{12}{|l|}{ June } \\
\hline $26 \ldots$ & 1.7 & $<.010$ & 200 & $<1$ & 3 & 100 & 70 & $<1$ & 3 & 2 & 10 \\
\hline \multicolumn{12}{|l|}{ July } \\
\hline $24 \ldots$ & - & - & - & - & - & - & - & - & - & - & - \\
\hline \multicolumn{12}{|l|}{ Aug } \\
\hline $28 .$. & 1.3 & $<.010$ & 200 & $<1$ & 2 & $<100$ & 100 & $<1$ & 2 & 1 & 7 \\
\hline Date & $\begin{array}{c}\text { Copper, } \\
\text { total } \\
\text { recov- } \\
\text { erable } \\
\text { (ugl) }\end{array}$ & $\begin{array}{l}\text { Copper, } \\
\text { recov- } \\
\text { erable } \\
\text { from bot- } \\
\text { tom ma- } \\
\text { terial } \\
(\mu g / g) \\
\end{array}$ & $\begin{array}{l}\text { Iron, } \\
\text { total } \\
\text { recov- } \\
\text { erable } \\
\text { (ugh) }\end{array}$ & $\begin{array}{l}\text { Lead, } \\
\text { total } \\
\text { recov- } \\
\text { erable } \\
(\mu g /))\end{array}$ & $\begin{array}{l}\text { Lead, } \\
\text { recov- } \\
\text { erable } \\
\text { from bot- } \\
\text { tom ma- } \\
\text { torial } \\
(\mu g / g)\end{array}$ & $\begin{array}{l}\text { Mercury, } \\
\text { total } \\
\text { recov- } \\
\text { erable } \\
\text { ( } \mu \mathrm{g} / \mathrm{L})\end{array}$ & $\begin{array}{c}\text { Mercury, } \\
\text { recov- } \\
\text { erable } \\
\text { from bot- } \\
\text { tom ma- } \\
\text { terlal } \\
(\mu g / g)\end{array}$ & $\begin{array}{l}\text { Nickel, } \\
\text { total } \\
\text { recov- } \\
\text { erable } \\
(\mu g /)\end{array}$ & $\begin{array}{l}\text { Selo- } \\
\text { nium, } \\
\text { total } \\
(\mu g / L)\end{array}$ & $\begin{array}{l}\text { Silver, } \\
\text { total } \\
\text { recov- } \\
\text { erable } \\
(\mu g / L)\end{array}$ & $\begin{array}{l}\text { Zinc, } \\
\text { total } \\
\text { recov- } \\
\text { erable } \\
\text { (ug/) }\end{array}$ \\
\hline \multicolumn{12}{|l|}{ Apr } \\
\hline $07 .$. & 2 & 30 & 120 & $<5$ & 230 & $<0.10$ & 0.05 & $<1$ & $<1$ & $<1$ & 20 \\
\hline $24 \ldots$ & - & - & - & - & - & - & - & - & - & - & - \\
\hline \multicolumn{12}{|l|}{ June } \\
\hline $26 \ldots$ & 2 & 10 & 150 & 3 & 230 & .10 & .02 & 1 & $<1$ & $<1$ & 30 \\
\hline \multicolumn{12}{|l|}{ July } \\
\hline $24 \ldots$ & - & - & - & - & - & - & - & - & - & - & - \\
\hline \multicolumn{12}{|l|}{ Aug } \\
\hline $28 . .$. & 4 & 10 & 120 & 3 & 220 & .10 & .05 & 1 & $<1$ & $<1$ & $<10$ \\
\hline
\end{tabular}


Table 23. Diel fluctuations in water-quality properties at site 2, upper San Antonio River, San Antonio, Texas, September 20-21, 1989

[ $\mu \mathrm{S} / \mathrm{cm}$, microsiemens per centimeter at $25^{\circ} \mathrm{C} ;{ }^{\circ} \mathrm{C}$, degrees Celsius; mg/L, milligrams per liter; -, not determined]

\begin{tabular}{|c|c|c|c|c|}
\hline $\begin{array}{l}\text { Time } \\
\text { (hour) }\end{array}$ & $\begin{array}{l}\text { Specific conductance } \\
(\mu \mathrm{S} / \mathrm{cm})\end{array}$ & $\begin{array}{c}\mathrm{pH} \\
\text { (standard units) }\end{array}$ & $\begin{array}{c}\text { Temperature } \\
\text { ('C) }\end{array}$ & $\begin{array}{c}\text { Dissolved oxygen } \\
\text { (mg/L) }\end{array}$ \\
\hline 1100 & 490 & 7.4 & 24.0 & 6.6 \\
\hline 1200 & - & 7.4 & 24.5 & 6.8 \\
\hline 1300 & - & 7.4 & 24.5 & 6.9 \\
\hline 1400 & - & 7.5 & 25.0 & 7.0 \\
\hline 1500 & - & 7.5 & 25.0 & 7.1 \\
\hline 1600 & - & 7.5 & 25.5 & 7.2 \\
\hline 1700 & - & 7.5 & 25.0 & 7.1 \\
\hline 1800 & - & 7.5 & 25.0 & 7.0 \\
\hline 1900 & - & 7.5 & 25.0 & 6.9 \\
\hline 2000 & - & 7.5 & 25.0 & 6.8 \\
\hline 2100 & - & 7.4 & 24.5 & 6.7 \\
\hline 2200 & - & 7.4 & 24.5 & 6.6 \\
\hline 2300 & - & 7.4 & 24.5 & 6.6 \\
\hline 2400 & - & 7.4 & 24.5 & 6.5 \\
\hline 0100 & - & 7.4 & 24.5 & 6.5 \\
\hline 0200 & - & 7.4 & 24.0 & 6.5 \\
\hline 0300 & - & 7.4 & 24.0 & 6.5 \\
\hline 0400 & - & 7.4 & 24.0 & 6.4 \\
\hline 0500 & - & 7.4 & 24.0 & 6.4 \\
\hline 0600 & - & 7.4 & 24.0 & 6.4 \\
\hline 0700 & - & 7.4 & 24.0 & 6.4 \\
\hline 0800 & - & 7.4 & 24.0 & 6.5 \\
\hline 0900 & - & 7.4 & 24.0 & 6.5 \\
\hline 1000 & - & 7.4 & 24.0 & 6.6 \\
\hline 1100 & - & 7.4 & 24.0 & 6.8 \\
\hline 1200 & 546 & 7.4 & 24.5 & 7.1 \\
\hline Minimum & - & 7.4 & 24.0 & 6.4 \\
\hline Maximum & - & 7.5 & 25.5 & 7.2 \\
\hline
\end{tabular}


Table 24. Diel fluctuations in water-quality properties at site 3, upper San Antonio River, San Antonio, Texas, September 19-20, 1989

[ $\mu \mathrm{S} / \mathrm{cm}$, microsiemens per centimeter at $25^{\circ} \mathrm{C}$; ${ }^{\circ} \mathrm{C}$, degrees Celsius; $\mathrm{mg} / \mathrm{L}$, milligrams per liter]

\begin{tabular}{|c|c|c|c|c|}
\hline $\begin{array}{c}\text { Time } \\
\text { (hour) }\end{array}$ & $\begin{array}{l}\text { Specific conductance } \\
\qquad(\mu \mathrm{S} / \mathrm{cm})\end{array}$ & $\begin{array}{c}\mathrm{pH} \\
\text { (standard units) }\end{array}$ & $\begin{array}{c}\text { Temperature } \\
\left.\text { ( }{ }^{\circ} \mathrm{C}\right)\end{array}$ & $\begin{array}{c}\text { Dissolved oxygen } \\
\text { (mg/L) }\end{array}$ \\
\hline 0700 & 477 & 7.7 & 24.5 & 5.8 \\
\hline 0800 & 481 & 7.7 & 24.5 & 5.8 \\
\hline 0900 & 483 & 7.7 & 24.5 & 5.8 \\
\hline 1000 & 485 & 7.7 & 24.5 & 6.0 \\
\hline 1100 & 486 & 7.7 & 24.5 & 6.1 \\
\hline 1200 & 487 & 7.8 & 24.5 & 6.2 \\
\hline 1300 & 488 & 7.8 & 25.0 & 6.4 \\
\hline 1400 & 488 & 7.8 & 25.0 & 6.5 \\
\hline 1500 & 489 & 7.8 & 25.0 & 6.6 \\
\hline 1600 & 490 & 7.8 & 25.0 & 6.6 \\
\hline 1700 & 491 & 7.8 & 25.0 & 6.7 \\
\hline 1800 & 491 & 7.8 & 24.5 & 6.7 \\
\hline 1900 & 492 & 7.8 & 24.5 & 6.6 \\
\hline 2000 & 493 & 7.8 & 24.5 & 6.5 \\
\hline 2100 & 493 & 7.8 & 24.5 & 6.5 \\
\hline 2200 & 495 & 7.8 & 24.5 & 6.4 \\
\hline 2300 & 496 & 7.8 & 24.5 & 6.4 \\
\hline 2400 & 496 & 7.8 & 24.5 & 6.5 \\
\hline 0100 & 497 & 7.8 & 24.5 & 6.4 \\
\hline 0200 & 498 & 7.8 & 24.5 & 6.4 \\
\hline 0300 & 499 & 7.8 & 24.5 & 6.3 \\
\hline 0400 & 500 & 7.8 & 24.5 & 6.2 \\
\hline 0500 & 501 & 7.8 & 24.5 & 6.1 \\
\hline 0600 & 502 & 7.8 & 24.5 & 6.0 \\
\hline 0700 & 503 & 7.8 & 24.5 & 5.9 \\
\hline 0800 & 504 & 7.8 & 24.5 & 5.9 \\
\hline Minimum & 477 & 7.7 & 24.5 & 5.8 \\
\hline Maximum & 504 & 7.8 & 25.0 & 6.7 \\
\hline
\end{tabular}

